University of Nebraska - Lincoln

DigitalCommons@University of Nebraska - Lincoln

Extension Farm and Ranch Management

Agricultural Economics Department

2020

Nebraska Farm Real Estate Market Highlights 2019-2020

Jim Jansen

University of Nebraska-Lincoln, jjansen4@unl.edu

Jeffrey Stokes

University of Nebraska-Lincoln, jeffrey.stokes@unl.edu

Follow this and additional works at: https://digitalcommons.unl.edu/ageconfarmmgmt

Part of the Agribusiness Commons, Agricultural and Resource Economics Commons, Entrepreneurial and Small Business Operations Commons, Management Information Systems Commons, Other Business Commons, Other Economics Commons, and the Real Estate Commons

Jansen, Jim and Stokes, Jeffrey, "Nebraska Farm Real Estate Market Highlights 2019-2020" (2020). Extension Farm and Ranch Management. 42.

https://digitalcommons.unl.edu/ageconfarmmgmt/42

This News Article is brought to you for free and open access by the Agricultural Economics Department at DigitalCommons@University of Nebraska - Lincoln. It has been accepted for inclusion in Extension Farm and Ranch Management by an authorized administrator of DigitalCommons@University of Nebraska - Lincoln. 


\section{NEBRASKA \\ FARM REAL ESTATE MARKET HIGHLIGHTS \\ 2019-2020 \\ Jim Jansen \\ Jeffrey Stokes}

\section{Department of Agricultural Economics University of Nebraska-Lincoln}

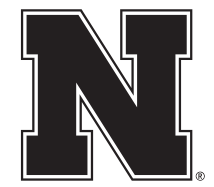




\title{
Nebraska Farm Real Estate Market Highlights \\ 2019-2020
}

\author{
By \\ Jim Jansen* \\ and \\ Jeffrey Stokes ${ }^{\star *}$
}
* Agricultural Economist, Eastern Nebraska Research and Extension Center;
Department of Agricultural Economics, University of Nebraska-Lincoln.
Phone: (402) 261-7572; email: jjansen4@unl.edu
${ }^{* *}$ Hanson-Clegg-Allen Endowed Chair, Agricultural Banking and Finance, Department of Agricultural Economics, University of Nebraska-Lincoln. Phone: (402) 472-2127; email: jeffrey.stokes@unl.edu

Sincere appreciation goes to the panel members for their participation in the UNL 2020 Nebraska Farm Real Estate Market Survey. Without their valuable input, much of the information within this report would not exist.

Special appreciation also goes to Dr. Bruce Johnson who conducted the UNL Nebraska Farm Real Estate Developments Survey from 1978 until his retirement in 2013. His advice and insight have been critical to the success of the survey and report.

Recognition is also extended to Linda Tesch, Mary Jarvi, and Ryan Evans for their significant contributions throughout the survey, report analysis, and publication process.

NOTE: This report is available at agecon.unl.edu/realestate

If electronic copies are not accessible, hard copies of these highlights can be purchased for $\$ 7.00$ per copy from:

Department of Agricultural Economics

University of Nebraska-Lincoln

Attn: Real Estate Report

207 Filley Hall

Lincoln, NE 68583-0922

It is the policy of the University of Nebraska-Lincoln not to discriminate based upon age, race, ethnicity, color, national origin, gender-identity, sex, pregnancy, disability, sexual orientation, genetic information, veteran's status, marital status, religion or political affiliation. 


\section{Disclaimer}

The Nebraska Farm Real Estate Market Highlights 2019-2020 publication was created for educational purposes to provide insight on recent trends in agricultural land values and rental rates across Nebraska. Agricultural land values and rental rates in the report represent averages for different regions of the state. Actual agricultural land values or rental rates for an individual parcel in Nebraska will vary from reported figures depending on quality attributes and local market forces of the area.

Agricultural land values and rental rates for this publication were obtained by surveying expert panel members engaged in agricultural land and rental markets throughout Nebraska. The panel members' validity relies on their expertise and accuracy and the authors do not make any guarantees as to their qualifications or the reliability of their responses. While survey responses were examined to eliminate data that was obviously erroneous, no further effort was made to independently verify or corroborate the data.

Physical attributes such as location, soil type, topography, or depth to water may affect the value of a given real property causing the value to deviate substantially from what may be considered normal for the area. Also, local market forces such as the competitive nature of an area and local government policies such as restrictions on the use of water all have the ability to greatly impact agricultural land values or rental rates.

In addition, variations exist within reporting Districts that may cause real estate values and rental rates to differ substantially within the region. As an example, the North reporting district spans almost 200 miles from east to west. Precipitation in Nebraska decreases, on average, one inch for every 25 miles a person travels westward, resulting in a possible decline of eight inches from the eastern side of this district to the west. An eight-inch difference in precipitation for a semi-arid region will substantially change the value and rental rates for crop and range ground.

Due to the inherent limitations of this survey, some of which are listed above, information in this report should not be used to set a specific rental rate or value a particular parcel of real property for sale or property taxes, security for a loan, and other related legal matters. 



\section{Table of Contents}

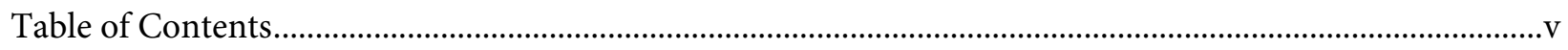

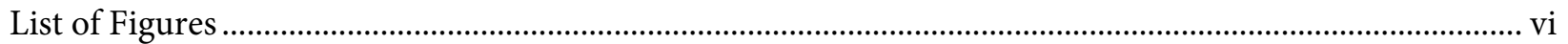

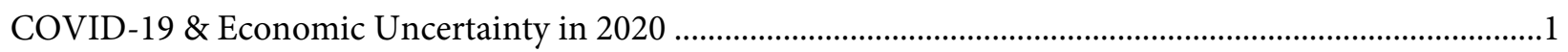

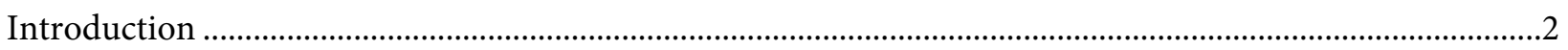

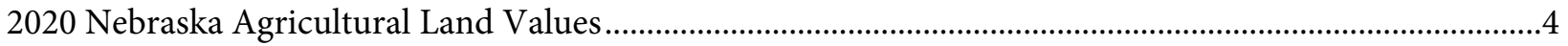

Table 1. Average Reported Value of Nebraska Farmland for Different Land Types by Agricultural Statistics District, February 1, 2020 ...........................................................................5

Table 2. 2020 Values and Recent Trends by Area of the State …..............................................................

Table 3. 2020 Values and Recent Trends by Land Class in Nebraska...............................................................

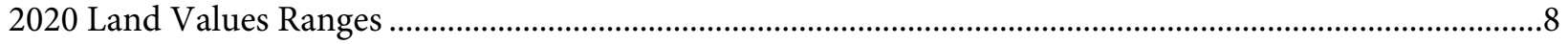

Table 4. Average Reported Value Per Acre of Nebraska Farmland for Different Types and Grades of Land in Nebraska by Agricultural Statistics District, February 1, 2020 .......................8

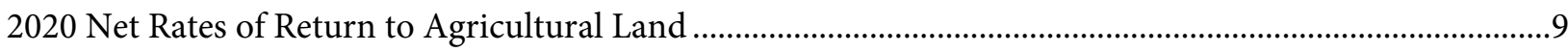

Table 5. Estimated Annual Net Rates of Return by Type of Land and Agricultural Statistics District, Selected Years 2016-2020 ......................................................................................................

Factors Influencing Current Agricultural Land Markets .............................................................................. 11

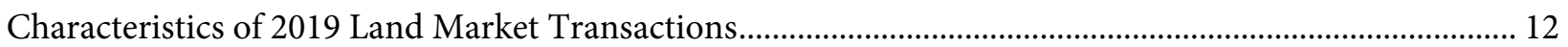

Table 6. Land Characteristics of 2019 Agricultural Real Estate Transactions, by Agricultural

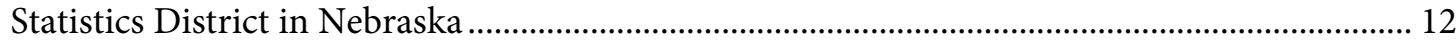

Table 7. Types of Financing Associated with 2019 Agricultural Real Estate Sales, by Agricultural Statistics District in Nebraska................................................................................ 13

Table 8. Percent Distribution of Agricultural Real Estate Transactions in 2019 by Buyer Type, by Agricultural Statistics District in Nebraska ................................................................................. 13

Table 9. Percent Distribution of Agricultural Real Estate Transactions in 2019 by Seller Type,

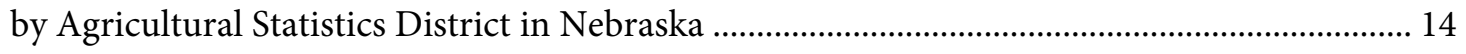

2020 Cash Rental Rates ................................................................................................................................. 15

Table 10. Reported Cash Rental Rates for Various Types of Nebraska Farmland and Pasture: 2020 Averages, Percent Change from 2019 and Quality Ranges by Agricultural Statistics District

Table 11. Reported Cash Rental Rates for Pasture on a Monthly Rate Basis for 2020: Averages and Ranges by Agricultural Statistics District

Special Feature: Historic Analysis of Flooding and Excessive Moisture Across Nebraska and

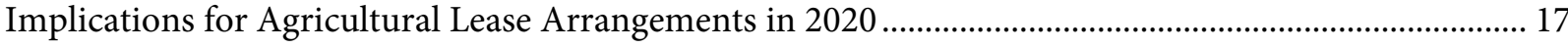

Table 12. Prevented Plant Acres by Year and Intended Crops for 2010-2019 in Nebraska ..................... 17

Table 13. Adjustments Made to Cash Rent on Cropland Having Extensive Prevented Plant for 2019 in Nebraska 


\section{Table of Contents (continued)}

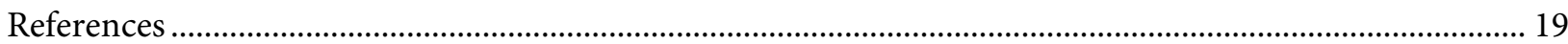

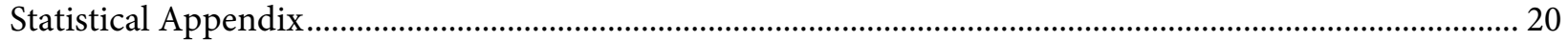

Appendix Table 1. Farm Real Estate Values in Nebraska, USDA Historical Series, 1860-2020 .............. 21

Appendix Table 2. Deflated USDA Farmland Values and Percent Changes for Nebraska, 1930

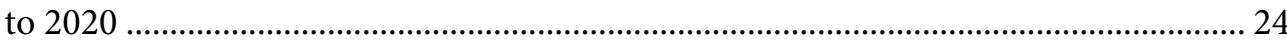

Appendix Table 3. Nominal and Deflated Agricultural Land Values by Selected Types of Land in Nebraska, 1978 to 2020 .

Appendix Table 4. Average Reported Value of Nebraska Farmland for Different Types of Land by Agricultural Statistics District, 1978-2020.

Appendix Table 5. Historical Per Acre Value Range for Different Types and Quality Grades of Land in Nebraska by Agricultural Statistics District, 2016-2020

Appendix Table 6. Estimated Annual Net Rates of Return to Nebraska Farmland for Different Types of Land by Agricultural Statistics District, 1990-2020 47

Appendix Table 7. Historical Average Cash Rental Rates of Nebraska Farmland for Different Types of Land by Agricultural Statistics District, 1981-2020

\section{List of Figures}

Figure 1. Nebraska Agricultural Statistics Districts

Figure 2. Average Value of Nebraska Farmland, February 1, 2020 and Percent Change from Year Earlier

Figure 3. Historical Nebraska All-Land Average Value per Acre and Marketing Year Average Price of Corn, Selected Years 1978-2020

Figure 4. Historical Estimated Annual Net Rates of Return by Land Type in Nebraska, Selected Years 1990-2020

Figure 5. Reporters' Rating of Factors Influencing Agricultural Land Values in Their Areas of Nebraska, February 2020

Figure 6. Land Industry Professional Response on Whether 2019 Land Leases Contained Provisions to Account for Damages from Flooding or Excessive Moisture in Nebraska 18

Figure 7. Land Industry Professional Response on Whether 2020 Lease Provisions Were Added or Revised to Account for Flooding or Excessive Moisture in Nebraska. 


\section{COVID-19 \& Economic Uncertainty in 2020}

Economic events surrounding the COVID-19 pandemic have introduced an unprecedented level of uncertainty and price declines in commonly grown crops or livestock produced across the state of Nebraska. Many lease provisions and cash rental rates were set prior to the economic shocks caused by COVID-19. The survey collection period for panel members that participated in the Nebraska Farm Real Estate Market Highlights 2019-2020 publication may reflect these rates and not fully account for possible adjustments made because of the economic shocks.

Recent reports by panel members indicate a high degree of pressure existing between landlords and tenants on setting an equitable cash rental rate due to deteriorating commodity and livestock prices in 2020. Many retired or absentee landowners are seeking a certain degree of return on their asset while facing high property taxes. Producers seeking to receive a positive return on rented properties face tight margins due to price declines.

Arriving at an equitable cash rental rate remains essential in 2020 to account for the needs of both parties involved in the lease. Landlords and tenants might consider amending contractual agreements to account for economic shocks or consider the use of alternative lease arrangements. These types of contractual agreements include flex or bonus leases and cash equivalent from crop share. Additional information may be found at: https://agecon.unl.edu/realestate. 


\section{Introduction}

The Nebraska Farm Real Estate Market Highlights 2019-20 report represents the $42^{\text {nd }}$ edition to the annual series. These reports provide an important insight on agricultural land market dynamics for stakeholders across Nebraska. In today's market, where market transactions exceeding \$1 million dollars are the norm, objective market information and analysis is more critical than ever. The focus of the report continues to be on providing unbiased information for agricultural land values and rental rates so industry participants can make educated and informed decisions.

This year, the February 2020 survey of nearly 120 expert panel members from across the state provided current information and insight regarding the agricultural land market conditions in their areas. The panel members have been selected on the basis of being actively engaged in agricultural land markets as certified agricultural appraisers, professional farm managers, agricultural lenders primarily focused on agricultural land transactions, and other professionals engaged in the Nebraska agricultural land industry due to the inherit nature of their positions. The majority of panelists participating in the survey have reported annually for a considerable number of years, which provides valuable historical consistency and context to the agricultural land values and rental rates provided.

Based on their knowledge of market activity, reporters provide point-in-time estimates of current agricultural land values and cash rental rates for a variety of land types and classes. Comparing these current measures against previous years' results provides important trend analysis. The appendix in this report includes: the historical UNL data series for Nebraska agricultural land values dating back to 1978, the agricultural cash rental rate series dating back to 1981, and the USDA historical all-land value series.

In addition to the point-in-time estimates, panel members provide details regarding actual sales transactions which have occurred over the previous 12 months. This year, the panel provided information on 447 sales that were considered representative of the recent agricultural land market. This gives insight into the characteristics of recent sales as well as benchmark indicators for studying trends. Changes in the nature of market participants engaged in land transactions from year to year may also be ascertained from evaluating this information. 
Figure 1. Nebraska Agricultural Statistics Districts

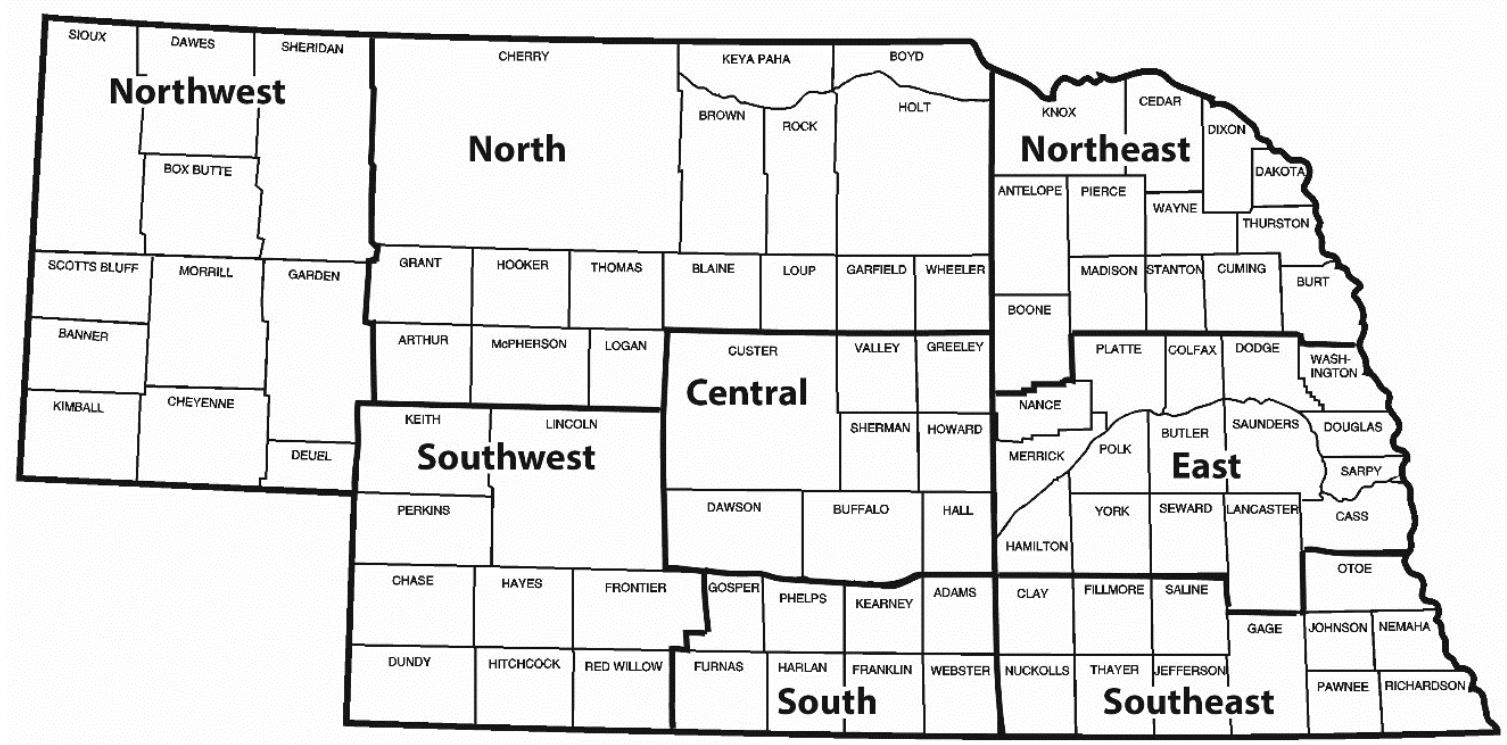

Nebraska has diverse land resource characteristics and agricultural patterns. Most of the market information is provided down to sub-state regions which are the Nebraska Agricultural Statistics Districts (Figure 1). Land within these regions shares similar geographical attributes and production expectations. The districts provide greater geographically-appropriate detail that are not available from other data sources, such as quarterly value estimates from the Kansas City Federal Reserve, the USDA-Economic Research Service Annual Farm Value and Cash Rent series for the state as a whole.

Variability exists within these eight sub-state regions. Therefore, sub-state regions of values and cash rents appropriately may not necessarily reflect the conditions of any local market in that geographic area. Differences in local values and rents can range from small to extreme. The information and analysis to follow in the report is a more realistic measure of general patterns and trends. Should one need information for one specific parcel, the services of a certified agricultural appraiser or a professional farm management firm should be solicited. 


\section{Nebraska Agricultural Land Values}

Reversing a half decade in market declines, the all-land average value in Nebraska for the year ending February 1, 2020 averaged about 3\% higher than the prior year. Figure 2 summarizes these figures and trends along with the percent changes over the prior year's all-land average for the eight districts in the state.

\section{Figure 2. Average Value of Nebraska Farmland, February 1, 2020 and Percent Change from Year Earlier}

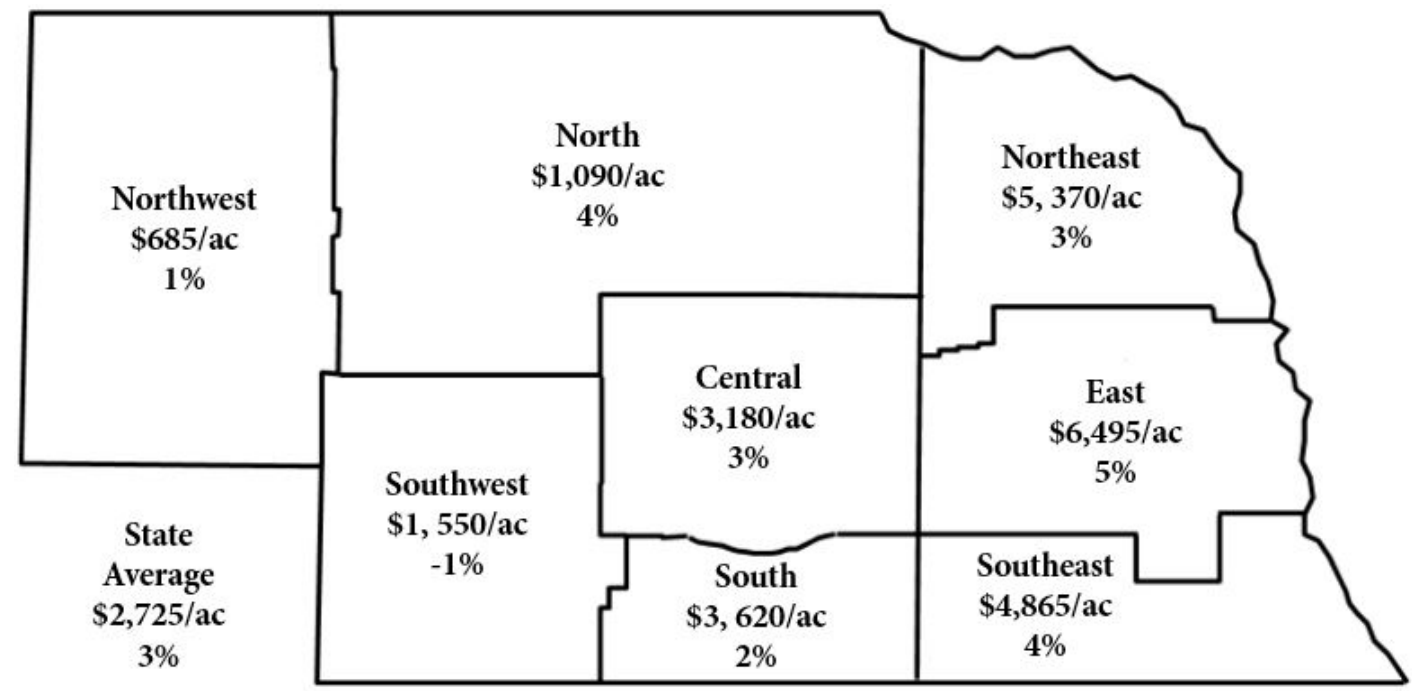

Source: UNL Nebraska Farm Real Estate Market Surveys, 2019 and 2020.

- The statewide all-land average value for the year ending February 1, 2020 averaged \$2,725 per acre, or about a 3\% (\$80 per acre) increase to the prior year's value of \$2,645 per acre (Figure 2).

- Rates of increase were the highest in the North, Northeast, Central, East, and Southeast Districts as these areas averaged 3\% to 5\% higher for the all-land average. These regions trended close to the rate of increase for the state.

- In the western regions of Nebraska, including the Northwest, Southwest, and Southern Districts reported small regional average changes. The Southwest District averaged $1 \%$ lower, whereas the Northwest or South Districts reported increases of $1 \%$ and $2 \%$.

- In 2020, panel members noted 1031 tax exchanges, non-farmer investor interest in land purchases, and current interest rate levels as forces guiding higher market values. These forces were reported as slightly positive on impacting future land prior to the domestic outbreak of COVID-19.

- The outlook for future declines remained bearish for several other factors including future property tax policies, current crop prices, farm input costs, and property tax levels. Concern remains for the liquidity and solvency of farm operators and land ownership expenses.

- Based on 2020 market values, the estimated total value of agricultural land and buildings in Nebraska fell to approximately $\$ 131.8$ billion. Appendix Table 1 gives a historical perspective on the estimated market value of land and related buildings in the state. Between 2019 and 2020, the market value increase in agricultural land and building totaled about $\$ 3.8$ billion. 
Table 1. Average Reported Value of Nebraska Farmland for Different Land Types by Agricultural Statistics District, February 1, 2020a

\begin{tabular}{|c|c|c|c|c|c|c|c|c|c|}
\hline \multirow{2}{*}{$\begin{array}{c}\text { Type of Land } \\
\text { and Year }\end{array}$} & \multicolumn{9}{|c|}{ Agricultural Statistics District } \\
\hline & Northwest & North & Northeast & Central & East & Southwest & South & Southeast & State $^{c}$ \\
\hline \multicolumn{10}{|c|}{ 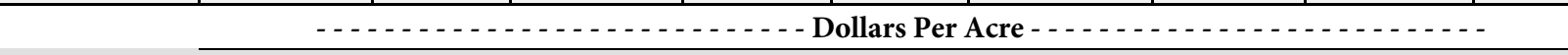 } \\
\hline \multicolumn{10}{|c|}{ Dryland Cropland (No Irrigation Potential) } \\
\hline \$/acre & 610 & 1,515 & 5,495 & 2,845 & 6,120 & 1,415 & 2,980 & 4,435 & 3,165 \\
\hline$\%$ change & -5 & 1 & 4 & 3 & 6 & -2 & 3 & 7 & 4 \\
\hline \multicolumn{10}{|c|}{ Dryland Cropland (Irrigation Potential) } \\
\hline$\$$ /acre & 695 & 1,975 & 5,765 & 3,210 & 6,550 & 1,545 & 3,495 & 5,330 & 4,140 \\
\hline$\%$ change & 2 & 3 & 2 & 5 & 7 & -3 & 1 & 1 & 3 \\
\hline \multicolumn{10}{|c|}{ Grazing Land (Tillable) } \\
\hline$\$ /$ acre & 520 & 1,105 & 3,220 & 1,875 & 3,190 & 925 & 1,835 & 2,920 & 1,240 \\
\hline$\%$ change & 4 & 6 & 3 & 7 & 4 & 5 & -2 & 6 & 5 \\
\hline \multicolumn{10}{|c|}{ Grazing Land (Nontillable) } \\
\hline$\$ /$ acre & 430 & 660 & 2,045 & 1,460 & 2,405 & 750 & 1,380 & 2,055 & 830 \\
\hline$\%$ change & 5 & 6 & 3 & 4 & 7 & 2 & 3 & 4 & 4 \\
\hline \multicolumn{10}{|l|}{ Hayland } \\
\hline$\$ /$ acre & 715 & 1,170 & 3,065 & 1,925 & 2,965 & 1,290 & 1,905 & 2,730 & 1,640 \\
\hline$\%$ change & 1 & 3 & 1 & 2 & -2 & 3 & -4 & 3 & 2 \\
\hline \multicolumn{10}{|c|}{ Gravity Irrigated Cropland } \\
\hline$\$ /$ acre & 2,135 & 3,645 & 6,700 & 5,805 & 7,725 & 3,570 & 5,450 & 6,235 & 5,755 \\
\hline$\%$ change & -5 & 2 & 3 & -1 & 2 & -4 & 2 & 6 & 1 \\
\hline \multicolumn{10}{|c|}{ Center Pivot Irrigated Cropland ${ }^{b}$} \\
\hline \$/acre & 2,460 & 3,950 & 7,390 & 6,675 & 8,900 & 3,990 & 6,465 & 7,680 & 6,125 \\
\hline$\%$ change & -4 & 1 & 2 & 4 & 5 & -3 & 5 & 3 & 3 \\
\hline \multicolumn{10}{|c|}{ All-Land Average $e^{c}$} \\
\hline$\$ /$ acre & 685 & 1,090 & 5,370 & 3,180 & 6,495 & 1,550 & 3,620 & 4,865 & 2,725 \\
\hline$\%$ change & 1 & 4 & 3 & 3 & 5 & -1 & 2 & 4 & 3 \\
\hline
\end{tabular}

Source: ${ }^{a}$ UNL Nebraska Farm Real Estate Market Surveys, 2019 and 2020.

${ }^{\mathrm{b}}$ Value of pivot not included in per acre value.

${ }^{c}$ Weighted averages.

- The February 1, 2020 Nebraska all-land average value of $\$ 2,725$ per acre marks a 3\% increase from the prior year (Table 1). In 2014, the statewide all-land value peaked at $\$ 3,315$, followed by a five-year decline for Nebraska until the trend reversed in 2020.

- Grazing land including tillable or non-tillable noted 5\% and $4 \%$ increases for statewide averages of $\$ 1,240$ and $\$ 830$ per acre. The grazing land tillable reported the highest increase out of the land classes. Major ranching areas including the North and Central, along with the Southeast District reported the largest improvements in value ranging from $6 \%$ to $7 \%$.

- Gravity and center pivot irrigated cropland noted smaller increases of $1 \%$ and $3 \%$ for the statewide average, at $\$ 5,755$ and $\$ 6,125$ per acre. Districts reporting improvements for the irrigated cropland included the Northeast, East, South, and Southeast ranging from about $2 \%$ to $6 \%$. The Northwest and Southwest Districts noted declines from $3 \%$ to $5 \%$ due to uncertainty with specialty crop production and appropriation restrictions according to panel members.

- Dryland cropland having no irrigation potential and with irrigation potential average \$3,165 and \$4,140 per acre or $4 \%$ and $3 \%$ higher than the prior year. The most strength for increases were in the Central, East, and Southeast Districts around 5\% to 7\%. Hayland reported a smaller increase of 2\% equating to an average of $\$ 1,640$ per acre. 
Figure 3. Historical Nebraska All-Land Average Value per Acre and Marketing Year Average Price of Corn, Selected Years 1978-2020

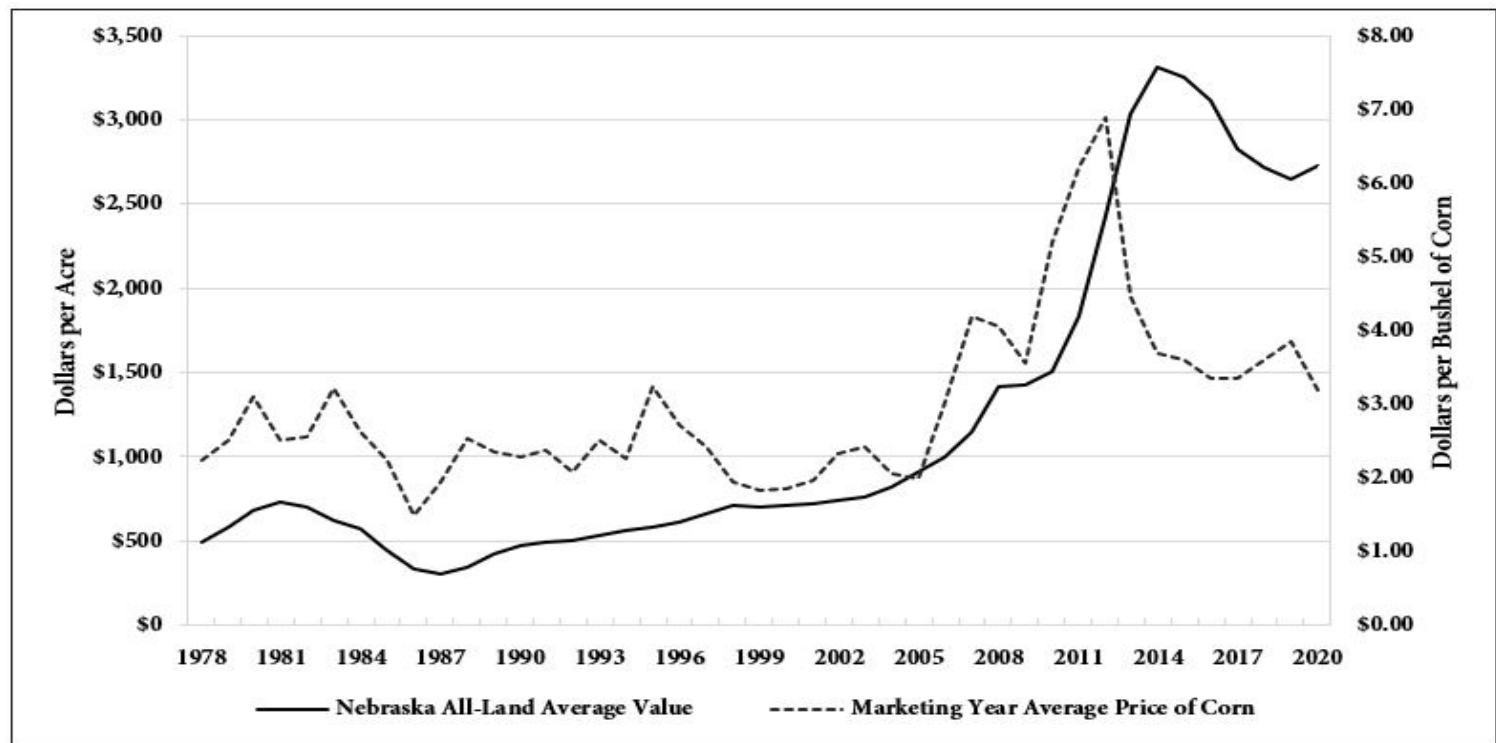

Source: a UNL Nebraska Farm Real Estate Market Surveys, 1978-2020.

b World Agricultural Supply and Demand Estimates (WASDE), Office of the Chief Economist, USDA, 1978-2020.

Preliminary Marketing Year Average price estimates for corn in 2019 and 2020.

- In 2020 the nominal (non-inflation adjusted) market value for the all-land average broke a fiveconsecutive year decline to improve to $\$ 2,725$ per acre (Figure 3). The price of corn in 2020 declined to a Marketing Year Average of $\$ 3.20$ per bushel.

- Economic events surrounding COVID-19 caused prices for major commodities produced across the state to drop further and revert to levels not seen since the mid to late 2000s. The financial stability of many farmers and ranchers remain a concern.

- Ad hoc and commodity safety net programs administrated by the United States Department of Agriculture have provided needed financial assistance to many agricultural producers according to panel members. Major ad hoc legislation increased substantially over the last year, including the Marketing Facilitation Program (MFP) and the Coronavirus Food Assistance Program (CFAP).

- Land ownership expenses in the form of current and future property tax policies ranked very negatively by panel members leading to potentially lower land values in the future. Reform in this area remains uncertain due to stress placed by COVID-19 on government outlays. 
Table 2. 2020 Values and Recent Trends by Area of the State ${ }^{a}$

\begin{tabular}{|c|c|c|c|c|}
\hline $\begin{array}{c}\text { Agricultural Statistics } \\
\text { District }\end{array}$ & $\begin{array}{l}2020 \text { All-Land } \\
\text { Average Value }\end{array}$ & 1-Year Change & 3-Year Change & 5-Year Change \\
\hline & \multicolumn{4}{|c|}{-- Percent Change -- } \\
\hline Northwest & 685 & 1 & -9 & -20 \\
\hline North & 1,090 & 4 & -7 & -18 \\
\hline Northeast & 5,370 & 3 & -2 & -13 \\
\hline Central & 3,180 & 3 & -6 & -20 \\
\hline East & 6,495 & 5 & 2 & -9 \\
\hline Southwest & 1,550 & -1 & -11 & -25 \\
\hline South & 3,620 & 2 & -7 & -22 \\
\hline Southeast & 4,865 & 4 & -0.3 & -19 \\
\hline Entire State & 2,725 & 3 & -3 & -16 \\
\hline
\end{tabular}

Source: ${ }^{a}$ Annual UNL Nebraska Farm Real Estate Market Surveys, 2015, 2017, 2019, and 2020.

- Across the state of Nebraska, the one-year change in the market value of land reported changes in the market value of land ranging from a $1 \%$ decline in the Southwest to a 5\% increase in the East District (Table 2).

- The Southwest and South Districts noted the largest market value declines from the prior five-year period at $25 \%$ and $22 \%$ each.

Table 3. 2020 Values and Recent Trends by Land Class in Nebraska ${ }^{a}$

\begin{tabular}{|c|c|c|c|c|}
\hline Land Class & $\begin{array}{c}2020 \text { Average } \\
\text { Value }\end{array}$ & 1-Year Change & 3-Year Change & 5-Year Change \\
\hline & Dollars/Acre & ----------------. & ercent Change --- & ------------- \\
\hline \multicolumn{5}{|l|}{ Dryland Cropland } \\
\hline No Irrigation Potential & 3,165 & 4 & 1 & -7 \\
\hline Irrigation Potential & 4,140 & 3 & -2 & -18 \\
\hline \multicolumn{5}{|l|}{ Grassland } \\
\hline Tillable & 1,240 & 5 & -7 & -18 \\
\hline Nontillable & 830 & 4 & -7 & -17 \\
\hline \multicolumn{5}{|l|}{ Hayland } \\
\hline All Classes & 1,640 & 2 & -10 & -30 \\
\hline \multicolumn{5}{|l|}{ Irrigated Cropland } \\
\hline Gravity & 5,755 & 1 & -5 & -17 \\
\hline Center Pivot $^{\mathrm{b}}$ & 6,125 & 3 & -3 & -16 \\
\hline All-Land & 2,725 & 3 & -3 & -16 \\
\hline
\end{tabular}

Source: ${ }^{a}$ Annual UNL Nebraska Farm Real Estate Market Surveys, 2015, 2017, 2019, and 2020.

${ }^{\mathrm{b}}$ Value of pivot not included in per acre value.

- By land class, grassland tillable and non-tillable reported the highest increase over the prior one-year period at $5 \%$ and $4 \%$ (Table 3). Dryland cropland with no irrigation potential also indicated a $4 \%$ increase over the prior year.

- Over the prior five-year period, dryland and irrigated cropland noted declines ranging from $7 \%$ to $18 \%$. Hayland displayed the largest decline at $30 \%$ as rainfall and availability of forages may greatly influence the land class. 


\section{Land Values Ranges}

In addition to the estimated average value of land, panel members reported high and low grade quality levels for each land class summarized in Table 4 . These averages create estimated quality value ranges for the seven reported land classes in Nebraska.

Table 4. Average Reported Value Per Acre of Nebraska Farmland for Different Types and Grades of Land in Nebraska by Agricultural Statistics District, February 1, 2020

\begin{tabular}{|c|c|c|c|c|c|c|c|c|}
\hline \multirow{2}{*}{$\begin{array}{c}\text { Type of Land } \\
\text { and Grade }\end{array}$} & \multicolumn{8}{|c|}{ Agricultural Statistics District } \\
\hline & Northwest & North & Northeast & Central & East & Southwest & South & Southeast \\
\hline & \multicolumn{8}{|c|}{ 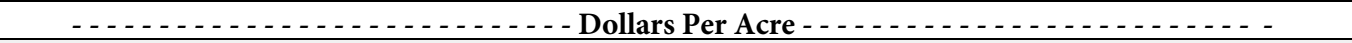 } \\
\hline \multicolumn{9}{|c|}{ Dryland Cropland (No Irrigation Potential) } \\
\hline Average & 610 & 1,515 & 5,495 & 2,845 & 6,120 & 1,415 & 2,980 & 4,435 \\
\hline High Grade & 795 & 1,880 & 6,720 & 3,330 & 7,350 & 1,610 & 3,475 & 5,490 \\
\hline Low Grade & 440 & 1,225 & 4,070 & 2,200 & 4,660 & 995 & 2,315 & 3,130 \\
\hline \multicolumn{9}{|c|}{ Dryland Cropland (Irrigation Potential) } \\
\hline Average & 695 & 1,975 & 5,765 & 3,210 & 6,550 & 1,545 & 3,495 & 5,330 \\
\hline High Grade & 875 & 2,310 & 6,825 & 3,690 & 7,640 & 1,755 & 4,170 & 6,320 \\
\hline Low Grade & 530 & 1,735 & 4,760 & 2,510 & 5,135 & 1,285 & 2,900 & 4,055 \\
\hline \multicolumn{9}{|c|}{ Grazing Land (Tillable) } \\
\hline Average & 520 & 1,105 & 3,220 & 1,875 & 3,190 & 925 & 1,835 & 2,920 \\
\hline High Grade & 615 & 1,300 & 3,835 & 2,350 & 4,005 & 1,140 & 2,180 & 3,495 \\
\hline Low Grade & 440 & 955 & 2,570 & 1,525 & 2,820 & 815 & 1,460 & 2,330 \\
\hline \multicolumn{9}{|c|}{ Grazing Land (Nontillable) } \\
\hline Average & 430 & 660 & 2,045 & 1,460 & 2,405 & 750 & 1,380 & 2,055 \\
\hline High Grade & 565 & 885 & 2,730 & 1,835 & 2,760 & 835 & 1,765 & 2,295 \\
\hline Low Grade & 370 & 520 & 1,685 & 1,110 & 2,045 & 620 & 1,225 & 1,810 \\
\hline \multicolumn{9}{|l|}{ Hayland } \\
\hline Average & 715 & 1,170 & 3,065 & 1,925 & 2,965 & 1,290 & 1,905 & 2,730 \\
\hline High Grade & 830 & 1,460 & 3,815 & 2,185 & 3,310 & 1,545 & 2,460 & 3,335 \\
\hline Low Grade & 545 & 1,010 & 2,290 & 1,620 & 2,445 & 1,095 & 1,300 & 2,080 \\
\hline \multicolumn{9}{|c|}{ Gravity Irrigated Cropland } \\
\hline Average & 2,135 & 3,645 & 6,700 & 5,805 & 7,725 & 3,575 & 5,450 & 6,235 \\
\hline High Grade & 2,865 & 4,390 & 7,920 & 6,410 & 8,840 & 4,125 & 6,570 & 7,430 \\
\hline Low Grade & 1,570 & 2,815 & 5,635 & 4,760 & 6,485 & 2,890 & 4,310 & 5,050 \\
\hline \multicolumn{9}{|c|}{ Center Pivot Irrigated Cropland ${ }^{b}$} \\
\hline Average & 2,460 & 3,950 & 7,390 & 6,675 & 8,900 & 3,990 & 6,465 & 7,680 \\
\hline High Grade & 3,000 & 5,135 & 8,465 & 7,635 & 9,875 & 4,610 & 7,350 & 8,745 \\
\hline Low Grade & 1,945 & 3,390 & 6,170 & 5,410 & 7,395 & 3,540 & 5,580 & 6,420 \\
\hline
\end{tabular}

Source: ${ }^{a}$ UNL Nebraska Farm Real Estate Market Survey, 2020.

${ }^{\mathrm{b}}$ Value of pivot not included in per acre value.

- The spread between high and low grade land classes widened in certain areas of Nebraska due to strong demand for better quality parcels according to panel members (Table 4). Variability of rainfall and geographic attributes also influenced the difference in values between better and poorer quality parcels.

- Over the prior year, differences in high and low grade land classes showed varying degrees of ability to handle excessive rain and flooding. Demand at the local level reflects this inherent attribute as panel members noted in the North, Central, and Southeast Districts.

- Excessive moisture and depressed commodity prices created challenging circumstance for many operations across the state in 2019. Prevented plant payments from crop insurance and the MFP helped to partially offset losses and provide a degree of stability to land markets. In 2019, Nebraska operators received about $\$ 965$ million from the MFP (USDA-FSA 2020a). 


\section{Net Rates of Return to Agricultural Land}

The net rates of return to agricultural land give an estimate on the net income earning potential relative to the value of the asset. Table 5 reports the estimated net rates of return for dryland cropland, irrigated cropland, and grazing land in Nebraska.

Table 5. Estimated Annual Net Rates of Return by Type of Land and Agricultural Statistics District, Selected Years 2016-2020 ${ }^{\text {ab }}$

\begin{tabular}{|c|c|c|c|c|c|c|c|c|c|}
\hline \multirow{2}{*}{$\begin{array}{c}\text { Type of Land } \\
\text { and Year }\end{array}$} & \multicolumn{8}{|c|}{ Agricultural Statistics District } & \multirow{2}{*}{$\begin{array}{c}\text { State } \\
\text { Average }\end{array}$} \\
\hline & Northwest & North & Northeast & Central & East & Southwest & South & Southeast & \\
\hline & \multicolumn{9}{|c|}{ 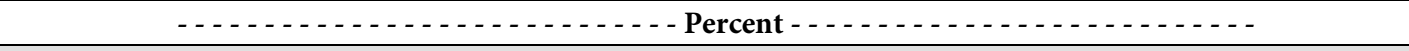 } \\
\hline \multicolumn{10}{|c|}{ Dryland Cropland } \\
\hline 2016 & 3.6 & 2.5 & 3.0 & 2.7 & 2.6 & 2.4 & 2.2 & 2.5 & 2.7 \\
\hline 2017 & 3.5 & 2.4 & 2.8 & 2.5 & 2.3 & 2.5 & 2.2 & 2.4 & 2.6 \\
\hline 2018 & 3.3 & 2.5 & 2.7 & 2.6 & 2.2 & 2.4 & 2.4 & 2.3 & 2.5 \\
\hline 2019 & 3.1 & 2.4 & 2.6 & 2.5 & 2.4 & 2.2 & 2.3 & 2.2 & 2.5 \\
\hline 2020 & 2.9 & 2.3 & 2.6 & 2.4 & 2.3 & 2.0 & 2.2 & 2.4 & 2.4 \\
\hline \multicolumn{10}{|c|}{ Irrigated Cropland } \\
\hline 2016 & 4.3 & 2.5 & 3.6 & 2.6 & 2.9 & 3.2 & 2.3 & 2.8 & 3.0 \\
\hline 2017 & 4.0 & 2.6 & 3.4 & 2.7 & 2.8 & 3.1 & 2.4 & 2.7 & 3.0 \\
\hline 2018 & 3.9 & 2.7 & 3.2 & 2.5 & 2.7 & 3.1 & 2.5 & 2.6 & 2.9 \\
\hline 2019 & 3.6 & 2.6 & 3.1 & 2.4 & 2.5 & 2.9 & 2.4 & 2.5 & 2.8 \\
\hline 2020 & 3.3 & 2.4 & 3.0 & 2.3 & 2.4 & 2.7 & 2.3 & 2.5 & 2.6 \\
\hline \multicolumn{10}{|l|}{ Grazing Land } \\
\hline 2016 & 2.2 & 2.7 & 2.6 & 2.1 & 2.0 & 2.3 & 2.1 & 1.5 & 2.2 \\
\hline 2017 & 2.1 & 2.5 & 2.4 & 2.0 & 1.7 & 2.1 & 1.9 & 1.6 & 2.0 \\
\hline 2018 & 2.1 & 2.6 & 2.2 & 1.9 & 1.8 & 2.0 & 1.8 & 1.7 & 2.0 \\
\hline 2019 & 2.0 & 2.3 & 2.1 & 1.7 & 1.8 & 1.9 & 2.0 & 1.6 & 1.9 \\
\hline 2020 & 1.9 & 2.2 & 2.0 & 1.5 & 1.9 & 1.8 & 2.0 & 1.7 & 1.9 \\
\hline
\end{tabular}

Source: ${ }^{\text {a } U N L ~ N e b r a s k a ~ F a r m ~ R e a l ~ E s t a t e ~ M a r k e t ~ S u r v e y s, ~ 2016-2020 . ~}$

${ }^{b}$ Panel members reported estimates of annual net returns as percentage rates of current land values. Real estate appraisers refer to this percentage as the market-derived capitalization rate.

- In 2020 for Nebraska, the statewide net rates of return (market derived capitalization rates) noted slight declines for dryland and irrigated cropland while remaining unchanged for grazing land (Table 5).

- Net rates of return on land reflect the earning potential from production or leasing out of the property and deducting for landownership expenses. High property taxes, depressed commodity prices, and appreciated land values have led to the historically low returns according to panel members.

- Across the eight districts the rate of return for dryland cropland varied from $2.0 \%$ to $2.9 \%$, whereas irrigated cropland fluctuated from 2.3\% to 3.3\%. Grazing land rates reported averages from a low of $1.5 \%$ to a high of $2.2 \%$. 
Figure 4. Historical Estimated Annual Net Rates of Return by Land Type in Nebraska, Selected Years 1990-2020

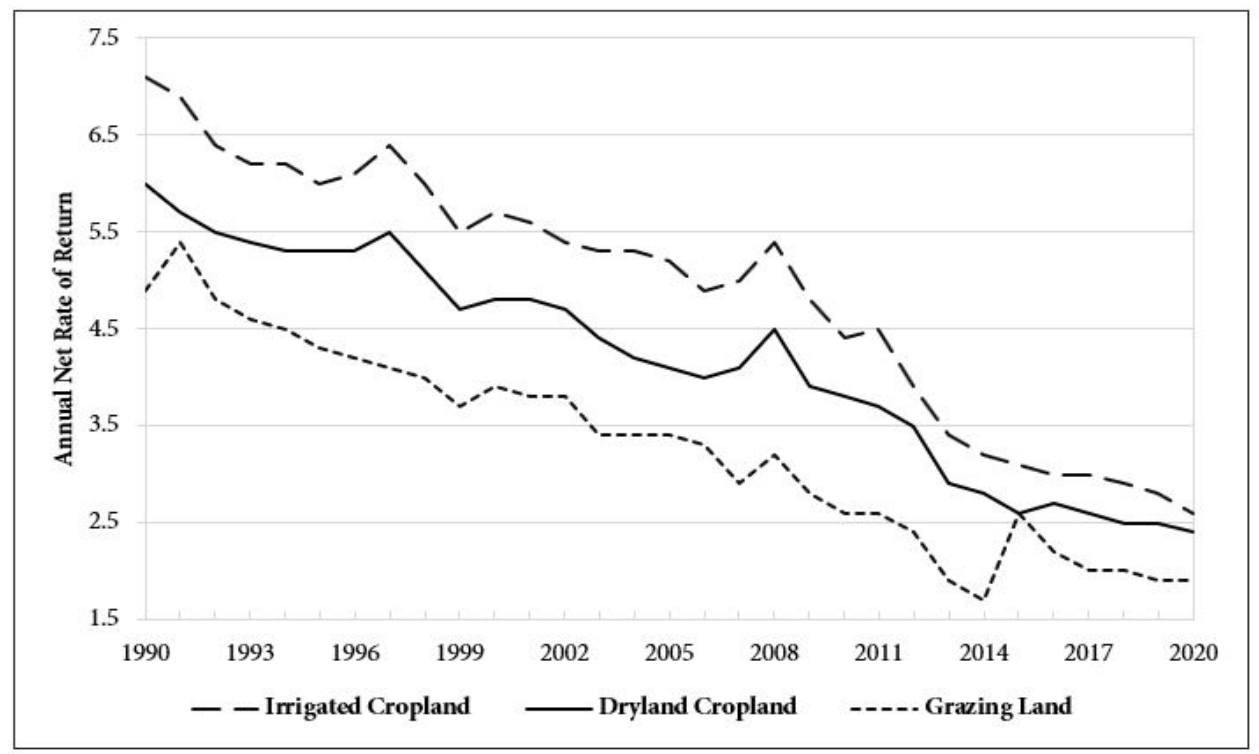

Source: a UNL Nebraska Farm Real Estate Market Surveys, 1990-2020.

- The rate of return dropped by $0.1 \%$ for dryland cropland to $2.4 \%$. In addition, the irrigated cropland rate of return dropped by $0.2 \%$ to $2.6 \%$ and grazing land remained steady at $1.9 \%$ (Figure 4 ).

- Current alternative investments with a comparable rate of return and risk to agricultural land remain low due to monetary policy enacted by the Federal Reserve System to counterbalance the economic effects of COVID-19. While net rates of return remain low, the level of risk relative to other investments still appears favorable to certain operators and private land owners making purchases.

- Institutional class investors looking to agricultural land in balancing portfolio risk requirements indicate that current property tax levels and net rates of return in Nebraska deter some from investing inside the state. Panel members also reiterate the need for long-term property tax reform as their outlook on future policies remain quite negative. 


\section{Factors Influencing Current Agricultural Land Markets}

Many economic factors contribute to the changes in agricultural land values during 2020. Figure 5 ranks and summarizes these factors based upon panel members' observations on their influences on land markets.

Figure 5. Reporters' Rating of Factors Influencing Agricultural Land Values in Their Areas of Nebraska, February 2020

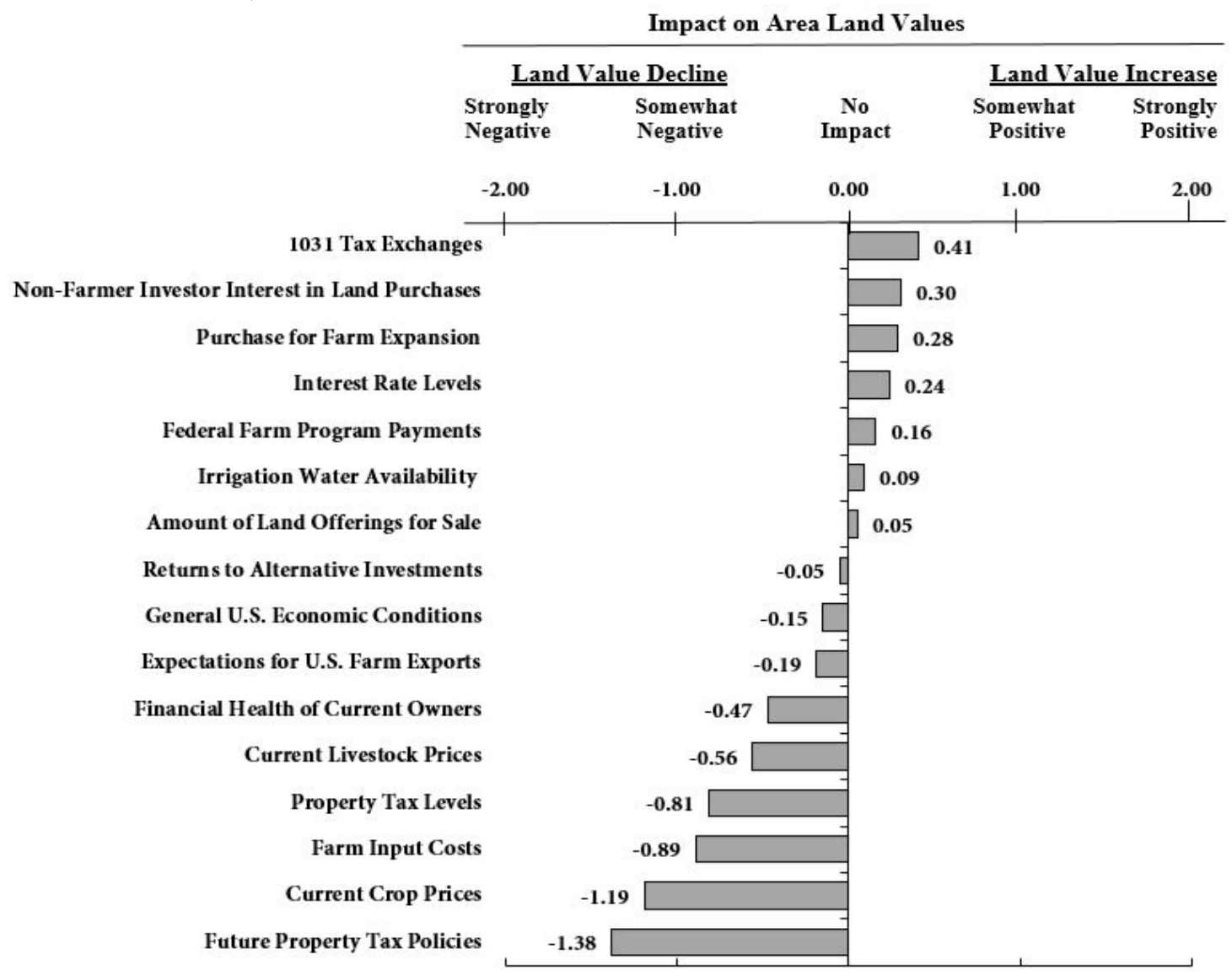

Source: UNL Nebraska Farm Real Estate Market Survey, 2020.

- Panel members expectations for increases in area land values improved as seven of the economic factors ranked as slightly to somewhat positive in 2020 (Figure 5). Interest in 1031 tax exchanges and purchases made by non-farm investors were the two most positive forces. New monetary policies by the Federal Reserve have reinforced the attractiveness of long-term interest rates for land purchases.

- Future property tax policies, current crop prices, and farm input costs appear as the three most negative factors leading to the decline in the market value of land. Other factors displaying somewhat negative features include those impacting commodity prices or the financial concerns of farm and ranch operations.

- Events surrounding the impact of COVID-19 on the agricultural sector and general economy has the potential to influence future changes in land values. Many factors remain uncertain around these economic events. 


\section{Characteristics of 2019 Land Market Transactions}

Each year, panel members provide specific details on actual land transactions considered to be representative of their local markets. Panel members reported details on 447 farm real estate transactions for 2019 in Nebraska and these transactions are reported in Tables $6,7,8$, and 9.

Table 6. Land Characteristics of 2019 Agricultural Real Estate Transactions, by Agricultural Statistics District in Nebraska

\begin{tabular}{|c|c|c|c|c|c|c|}
\hline \multirow{2}{*}{$\begin{array}{c}\text { Agricultural } \\
\text { Statistics District }\end{array}$} & \multirow{2}{*}{$\begin{array}{c}\text { Average Size } \\
\text { of Tract }\end{array}$} & \multicolumn{3}{|c|}{ Average Percent Distribution } & \multicolumn{2}{|c|}{ Average Price } \\
\hline & & $\begin{array}{l}\text { Dryland } \\
\text { Cropland }\end{array}$ & $\begin{array}{l}\text { Irrigated } \\
\text { Cropland }\end{array}$ & Pasture & Per Acre & Per Tract \\
\hline & - - Acres - - & \multicolumn{3}{|c|}{ 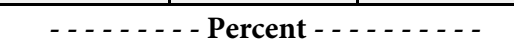 } & \multicolumn{2}{|c|}{ - . - _ - Dollars - . . . } \\
\hline Northwest & 872 & 16 & 14 & 70 & 798 & 696,072 \\
\hline North & 1,388 & 2 & 10 & 88 & 1,034 & $1,435,565$ \\
\hline Northeast & 148 & 62 & 24 & 14 & 5,877 & 869,150 \\
\hline Central & 249 & 15 & 52 & 33 & 3,869 & 964,326 \\
\hline East & 108 & 49 & 39 & 12 & 6,641 & 718,928 \\
\hline Southwest & 316 & 27 & 21 & 52 & 1,622 & 513,093 \\
\hline South & 165 & 45 & 25 & 30 & 3,517 & 579,471 \\
\hline Southeast & 132 & 56 & 29 & 15 & 5,015 & 662,926 \\
\hline State & 214 & 33 & 25 & 42 & 3,637 & 776,793 \\
\hline
\end{tabular}

Source: Based on 447 transactions which occurred across Nebraska during 2019 and reported in the UNL Nebraska Farm Real Estate Market Survey, 2020.

- In 2019 the average parcel size of land sold in Nebraska was 214 acres according to Table 6 . These sales equated to an average sale price of $\$ 776,793$ per tract, or a price of $\$ 3,637$ per acre. On a per-acre basis, the highest prices per acre were located in the Northeast and East Districts, at $\$ 5,877$ and $\$ 6,641$ per acre. The lowest price per acre appeared in the Northwest and North Districts at \$798 and \$1,034 per acre.

- Land sales located in the primary regions of Nebraska tended to reflect the larger tract transactions as those reported in Northwest and North Districts were 872 and 1,388 acres. These sales had the highest proportion of pasture sales. Outside of the major ranching regions, land transactions ranged in size from low of 132 acres in the Southeast to 316 acres in the Southwest District.

- The largest decline in percent of land sold by types from 2018 to 2019 was pasture in the Central District. In $2019,33 \%$ of land sold in the Central District was pasture or about $17 \%$ lower than the prior reporting year.

- The largest increase in percent of land sold by type from 2018 to 2019 was pasture in the North District. For 2019, 88\% of the land sold in the North District was pasture compared to 77\% in 2018. 
Table 7. Types of Financing Associated with 2019 Agricultural Real Estate Sales, by Agricultural Statistics District in Nebraska

\begin{tabular}{l|c|c|c|c|}
\hline \multirow{1}{*}{$\begin{array}{c}\text { Agricultural } \\
\text { Statistics District }\end{array}$} & \multicolumn{4}{c|}{ Financing of Purchase } \\
\cline { 2 - 5 } Northwest & Cash Purchase & Mortgage & Contract For Deed & Other \\
\cline { 2 - 5 } North & 43 & 57 & 0 & 0 \\
Northeast & 56 & 39 & 6 & 0 \\
Central & 40 & 49 & 6 & 4 \\
East & 63 & 35 & 0 & 3 \\
Southwest & 47 & 49 & 3 & 0 \\
South & 17 & 33 & 4 & 6 \\
Southeast & 61 & 37 & 0 & 3 \\
\hline State & 58 & $\mathbf{4 5}$ & 2 & $\mathbf{3}$ \\
\hline
\end{tabular}

Source: Based on 447 transactions which occurred across Nebraska during 2019 and reported in the UNL Nebraska Farm Real Estate Market Survey, 2020.

- Mortgages and alternative sources of financing picked up while cash purchases declined to make land purchases in 2019 (Table 7). Cash purchases declined from 53\% to $49 \%$ while the other sources of financing increased by $4 \%$.

- Financial circumstances stemming from COVID-19 might cause the proportion of land transactions from cash purchases to decline while other sources could increase over the upcoming year.

Table 8. Percent Distribution of Agricultural Real Estate Transactions in 2019 by Buyer Type, by Agricultural Statistics District in Nebraska

\begin{tabular}{|c|c|c|c|c|}
\hline \multirow{2}{*}{$\begin{array}{c}\text { Agricultural } \\
\text { Statistics District }\end{array}$} & \multicolumn{4}{|c|}{ Type of Buyer } \\
\hline & $\begin{array}{c}\text { Active } \\
\text { Farmer/Rancher }\end{array}$ & $\begin{array}{c}\text { Local } \\
\text { Non-Farmer }\end{array}$ & $\begin{array}{c}\text { Non-Local Nebraska } \\
\text { Resident }\end{array}$ & $\begin{array}{c}\text { Out-of-State } \\
\text { Buyer }\end{array}$ \\
\hline & \multicolumn{4}{|c|}{ - - - - - - - - - - - - - Percent - - - - - - - - - - - - - - } \\
\hline Northwest & 57 & 29 & 14 & 0 \\
\hline North & 67 & 16 & 6 & 11 \\
\hline Northeast & 63 & 21 & 11 & 5 \\
\hline Central & 88 & 7 & 2 & 3 \\
\hline East & 72 & 13 & 11 & 4 \\
\hline Southwest & 65 & 18 & 13 & 4 \\
\hline South & 78 & 5 & 17 & 0 \\
\hline Southeast & 85 & 9 & 1 & 5 \\
\hline State & 74 & 14 & 8 & 4 \\
\hline
\end{tabular}

- Nebraska operators including active farmers or ranchers and local non-farmers accounted for $88 \%$ of land sales in 2019, as shown in Table 9. Active farmers or ranchers lead purchases in the state at $74 \%$ followed by local non-farmers at $14 \%$.

- Approximately $12 \%$ of transactions non-local Nebraska residents and out of state buyers accounted for a smaller share of purchases. The highest share of out-of-state buyers was reported in the North District. 
Table 9. Percent Distribution of Agricultural Real Estate Transactions in 2019 by Seller Type, by Agricultural Statistics District in Nebraska

\begin{tabular}{|c|c|c|c|c|c|c|}
\hline \multirow{2}{*}{$\begin{array}{c}\text { Agricultural } \\
\text { Statistics } \\
\text { District }\end{array}$} & \multicolumn{6}{|c|}{ Type of Seller } \\
\hline & $\begin{array}{l}\text { Active } \\
\text { Farmer }\end{array}$ & $\begin{array}{l}\text { Quitting } \\
\text { Farmer }\end{array}$ & Estate & $\begin{array}{c}\text { Local } \\
\text { Non-Farmer }\end{array}$ & $\begin{array}{c}\text { Non-Local NE } \\
\text { Resident }\end{array}$ & $\begin{array}{c}\text { Out-of-State } \\
\text { Resident }\end{array}$ \\
\hline & \multicolumn{6}{|c|}{$\begin{array}{l}-\ldots \\
\end{array}$} \\
\hline Northwest & 43 & 13 & 29 & 15 & 0 & 0 \\
\hline North & 61 & 4 & 17 & 6 & 11 & 1 \\
\hline Northeast & 10 & 22 & 49 & 8 & 7 & 4 \\
\hline Central & 25 & 13 & 43 & 15 & 1 & 3 \\
\hline East & 15 & 23 & 34 & 11 & 8 & 9 \\
\hline Southwest & 26 & 4 & 22 & 35 & 4 & 9 \\
\hline South & 17 & 6 & 39 & 22 & 11 & 5 \\
\hline Southeast & 19 & 18 & 40 & 14 & 6 & 3 \\
\hline State & 18 & 18 & 39 & 13 & 7 & 5 \\
\hline
\end{tabular}

Source: Based on 447 transactions which occurred across Nebraska during 2019 and reported in the UNL Nebraska Farm Real Estate Market Survey, 2020.

- Around $88 \%$ of land sale transactions came from active or quitting farmers, estates, and local-non farmers in Nebraska during 2019 (Table 9). Non-local Nebraska and out-of-state residents comprised the other $12 \%$ of sales.

- With the aging farm population, estate sales contributed the largest proportion of land sales in Nebraska. Regionally, this type of sales fluctuated from a high of $49 \%$ in the Northeast to a low of $17 \%$ in the North District.

- Active farmers contributed to about $18 \%$ of sale transactions. This category remained steady with prior reporting years as a major change did not occur from the average reported in 2018. 


\section{Cash Rental Rates}

Cash rental rates, on average, were steady to slightly higher across Nebraska in 2020. Table 10 summarizes average cash rental rates for 2020, percent changes from the prior year, and the high and low third quality grade averages for the state.

Table 10. Reported Cash Rental Rates for Various Types of Nebraska Farmland and Pasture: 2020 Averages, Percent Change from 2019 and Quality Ranges by Agricultural Statistics District ${ }^{\mathrm{a}}$

\begin{tabular}{|c|c|c|c|c|c|c|c|c|}
\hline \multirow{2}{*}{ Type of Land } & \multicolumn{8}{|c|}{ Agricultural Statistics District } \\
\hline & Northwest & North & Northeast & Central & East & Southwest & South & Southeast \\
\hline \multicolumn{9}{|c|}{ - } \\
\hline \multicolumn{9}{|l|}{ Dryland Cropland } \\
\hline Average .............................. & 28 & 52 & 215 & 91 & 205 & 37 & 76 & 165 \\
\hline \% Change..................... & 2 & 3 & 5 & 8 & 2 & -3 & 4 & 6 \\
\hline High Third Quality... & 39 & 85 & 255 & 105 & 235 & 54 & 110 & 190 \\
\hline Low Third Quality..... & 23 & 41 & 170 & 74 & 165 & 30 & 49 & 130 \\
\hline \multicolumn{9}{|l|}{ Gravity Irrigated Cropland } \\
\hline 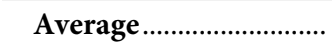 & 105 & 170 & 260 & 205 & 255 & 160 & 205 & 230 \\
\hline \% Change ..................... & -5 & 3 & 2 & 5 & 4 & 3 & 8 & 5 \\
\hline High Third Quality... & 130 & 200 & 295 & 240 & 285 & 190 & 235 & 265 \\
\hline Low Third Quality..... & 80 & 125 & 215 & 170 & 220 & 125 & 170 & 195 \\
\hline \multicolumn{9}{|c|}{ Center Pivot Irrigated Cropland ${ }^{\text {b }}$} \\
\hline 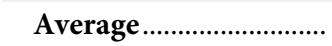 & 140 & 195 & 290 & 230 & 280 & 185 & 220 & 265 \\
\hline \% Change ..................... & -3 & 5 & 4 & 7 & -2 & 5 & 7 & 6 \\
\hline High Third Quality... & 175 & 235 & 325 & 265 & 320 & 215 & 255 & 300 \\
\hline Low Third Quality..... & 105 & 165 & 245 & 190 & 245 & 160 & 180 & 225 \\
\hline \multicolumn{9}{|l|}{ Pasture } \\
\hline 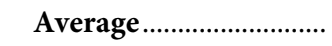 & 12 & 26 & 63 & 35 & 51 & 20 & 37 & 48 \\
\hline \% Change ..................... & 9 & 6 & 8 & 11 & 9 & 5 & 10 & 4 \\
\hline High Third Quality... & 18 & 43 & 78 & 44 & 67 & 28 & 45 & 62 \\
\hline Low Third Quality..... & 9 & 14 & 46 & 31 & 39 & 18 & 26 & 36 \\
\hline
\end{tabular}

- Dryland and irrigated cropland reported steady to slightly higher cash rental rates (Table 10). The rise in dryland cropland rental rates ranged from $2 \%$ in the Northwest and East to $8 \%$ in the Central District. Irrigated rental rates generally trended up at a similar rate. Exceptions existed as the Northwest, East, and Southwest District reported small declines in certain cases.

- Productivity of the cropland including soil types, degree of slope, expected rainfall, and location all influence the competitiveness of rent paid in an area according to panel members. These differences by district provide the range and average paid in cash rent from the low third to high third quality.

- Evaluating productivity of the cropland and expected commodity price remains essential in reaching an equitable cash rental rate in 2020. Much uncertainty exists around prices due to economic events surrounding COVID-19.

- Pasture rental rates on a per acre basis increased from about $4 \%$ to $11 \%$. Factors reported as influencing these rental rates included overall range quality, stocking rates, and geographical limitations. 
Table 11. Reported Cash Rental Rates for Pasture on a Monthly Rate Basis for 2020: Averages and Ranges by Agricultural Statistics District ${ }^{\mathrm{a}}$

\begin{tabular}{|c|c|c|c|c|c|c|c|c|}
\hline \multirow{2}{*}{ Type } & \multicolumn{8}{|c|}{ Agricultural Statistics District } \\
\hline & Northwest & North & Northeast & Central & East & Southwest & South & Southeast \\
\hline \multicolumn{9}{|c|}{ ( } \\
\hline \multicolumn{9}{|c|}{ Cow-Calf Pair Monthly Rates ${ }^{\mathrm{b}}$} \\
\hline 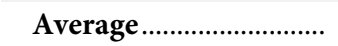 & 37.90 & 61.45 & 57.80 & 54.70 & 51.35 & 49.90 & 47.10 & 50.45 \\
\hline High Third Quality... & 44.75 & 69.30 & 72.95 & 65.10 & 63.80 & 59.45 & 56.70 & 58.25 \\
\hline Low Third Quality..... & 33.70 & 50.85 & 45.35 & 39.50 & 44.15 & 42.00 & 38.40 & 36.55 \\
\hline \multicolumn{9}{|c|}{ Stocker (500-600 lb.) Monthly Rates } \\
\hline Average ............................... & 23.10 & 34.95 & 38.55 & 31.80 & 37.45 & 33.20 & 31.70 & 35.95 \\
\hline High Third Quality... & 31.00 & 42.30 & 46.70 & 41.20 & 45.05 & 41.80 & 38.25 & 43.45 \\
\hline Low Third Quality..... & 18.65 & 28.55 & 29.10 & 23.65 & 28.60 & 27.15 & 25.30 & 26.80 \\
\hline
\end{tabular}

- Cow-calf and stocker rental rates were steady compared to averages reported in the prior year as shown in Table 11. Rental rates for cow-calf pairs or stockers represent the typical grazing fee for one month during the summer growing season. The monthly rates would typically be multiplied by five months for a grazing season fee.

- Upkeep on grazing land improvements serves as one of the main negotiation terms discussed as part of the lease arrangement. A landlord or tenant's willingness to control brush or weeds, maintain fencing, and ensure access to water all must be considered as part of the cash rent. Panel members reported that, depending upon the agreement reached, the final rate paid may vary according to the contribution of each party involved in the lease.

- Grazing land properties in certain areas of Nebraska experienced extensive flooding in 2019. These properties may require remediation efforts or reduced stocking rates until the land has recovered. Accounting for these issues and adjusting management plans should be accounted in the annual grazing land lease. 


\section{Special Feature: Historic Analysis of Flooding and Excessive Moisture Across Nebraska and Implications for Agricultural Lease Arrangements in 2020}

Each year, the special feature section covers topics on new or emerging issues related to the agricultural land industry in Nebraska. These topics reflect interest expressed by panel members and readership of the Nebraska Farm Real Estate Market Highlights Reports. The special feature section in 2020 evaluates historic flooding and excessive moisture over the prior decade across Nebraska and implications on accounting for this type of risk in agricultural lease arrangements.

Reported prevented plant acres and intended crop over the prior decade in Table 12 documents the effects of excessive moisture and flooding across Nebraska (USDA-FSA 2020b). Prevented plant acres represent the failure to plant the intended crop by the final planting date or late planting period specified by the Federal Crop Insurance Policy (USDA-RMA 2020). Coverage provided by the Federal Crop Insurance Policy offsets a portion of the financial loss from prevented plant on cropland.

Table 12. Prevented Plant Acres by Year and Intended Crops for 2010-2019 in Nebraska ${ }^{a}$

\begin{tabular}{|c|c|c|c|c|c|c|}
\hline \multirow{2}{*}{ Crop Year } & \multicolumn{6}{|c|}{ Prevented Plant Acres and Intended Crops } \\
\hline & Corn & Sorghum & Soybeans & Wheat & Other & Total $^{\text {b }}$ \\
\hline & \multicolumn{6}{|c|}{ ـ } \\
\hline 2010 & 21,221 & 1,235 & 10,061 & 6,128 & 49 & 38,693 \\
\hline 2011 & 29,279 & 0 & 11,088 & 15 & 11 & 40,394 \\
\hline 2012 & 3,890 & 0 & 2,286 & 0 & 0 & 6,177 \\
\hline 2013 & 11,518 & 8 & 2,591 & 1,303 & 0 & 15,420 \\
\hline 2014 & 9,895 & 6 & 1,654 & 720 & 0 & 12,275 \\
\hline 2015 & 129,179 & 3,881 & 54,996 & 128 & 279 & 188,463 \\
\hline 2016 & 38,922 & 19 & 4,934 & 73 & 5 & 43,953 \\
\hline 2017 & 17,222 & 0 & 1,696 & 0 & 0 & 18,918 \\
\hline 2018 & 18,956 & 361 & 5,325 & 406 & 0 & 25,048 \\
\hline 2019 & 344,407 & 3,250 & 71,958 & 1,584 & 760 & 421,958 \\
\hline Avg. 2010 - 2019 & 62,449 & 876 & 16,659 & 1,036 & 110 & 81,130 \\
\hline
\end{tabular}

Source: ${ }^{a}$ Crop Acreage Data Reported to USDA-Farm Service Agency, 2010-2019.

${ }^{\mathrm{b}}$ Difference between the total and sum of individual rows due to rounding.

- Nebraska reported an average of 81,130 acres of prevented plant cropland from 2010 to 2019. The top three crops for prevented plant in the state annually included corn, soybeans, and wheat at $62,449,16,659$, and 1,036 acres.

- Rainfall and flooding events in 2015 and 2019 attributed to the highest number of prevented plant cropland at 188,463 and 421,958 acres. Excluding these two years from the prior decade drops the annual average to approximately 25,110 acres of prevent plant.

According to the 2017 Census of Agriculture, Nebraska has approximately 22 million acres of dryland and irrigated cropland (USDA-NASS 2019). Dividing the annual prevented plant acres by total cropland indicates that less than $1 \%$ of the land base typically experiences water related issues. With the low probability of prevent plant in Nebraska many land leases may focus on other forms of contractual risk. Figure 6 summarizes whether agricultural land lease arrangements contained mitigation provisions to address damages from flooding or excessive moisture in 2019 across the state. 
Figure 6. Land Industry Professional Response on Whether 2019 Land Leases Contained Provisions to Account for Damages from Flooding or Excessive Moisture in Nebraska

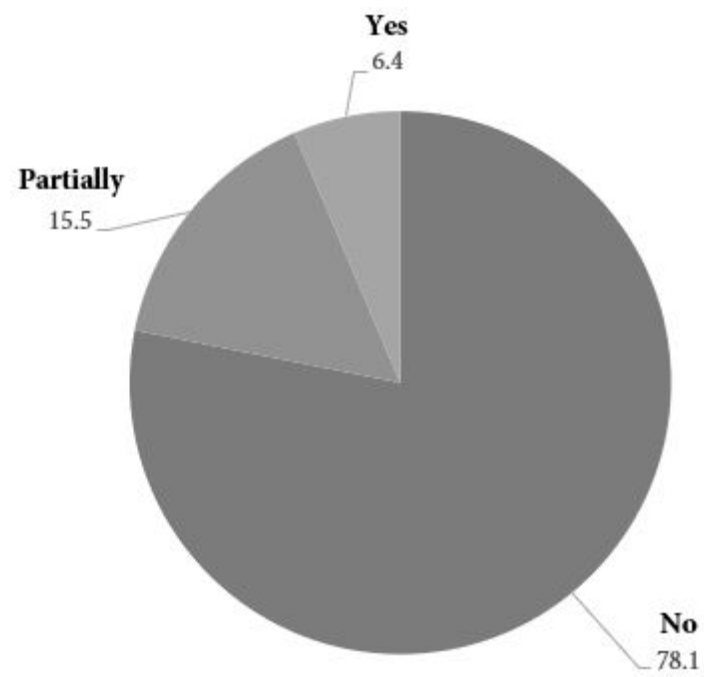

Source: UNL Nebraska Farm Real Estate Market Survey, 2020.

- In Figure 6 panel members reported 78.1\% of agricultural land leases in 2019 did not contain provisions to account for damages from flooding or excessive moisture.

- About $15.5 \%$ of the leases partially accounted for this type of risk while approximately $6.4 \%$ of the leases fully contained mitigation provisions. Failure to account for flooding or excessive moisture leaves uncertainty in addressing property damages and limitations imposed on the land.

With over 421 thousand acres of prevented plant cropland in Nebraska in 2019, many cropland leases did not have adequate lease provisions to address the issues arising from the disruption to the production cycles. Table 13 summarizes responses from panel members on adjustments made to the cash rent for cropland if the property experienced extensive prevented plant during 2019.

Table 13. Adjustments Made to Cash Rent on Cropland Having Extensive Prevented Plant for 2019 in Nebraska

\begin{tabular}{|l|c|}
\hline Adjustment to Cash Rent & Response Rate \\
\hline & $\ldots \ldots$ - - Percent $\ldots \ldots \ldots$ \\
\cline { 2 - 2 } No Adjustments $\ldots$ & 36.4 \\
Reduced Rent & 39.1 \\
No Rent & 10.3 \\
Other & 14.2 \\
\hline
\end{tabular}

Source: UNL Nebraska Farm Real Estate Market Survey, 2020.

- According to Table 13, approximately $36.4 \%$ of cropland leases had no adjustment made to the cash rent when extensive prevent plant occurred on the property. About $39.1 \%$ of cropland leases reported reduced rent due to excessive moisture or flooding.

- The remaining $24.5 \%$ of leases either did not have any rent paid or some other alternative agreement added to the lease. Operators may have traded remediation work to damages on properties to partially offset a portion of the cash rent due. 
Figure 7 summarizes reported changes to 2020 cropland leases to better account for risk from flooding or excessive moisture.

Figure 7. Land Industry Professional Response on Whether 2020 Lease Provisions Were Added or Revised to Account for Flooding or Excessive Moisture in Nebraska

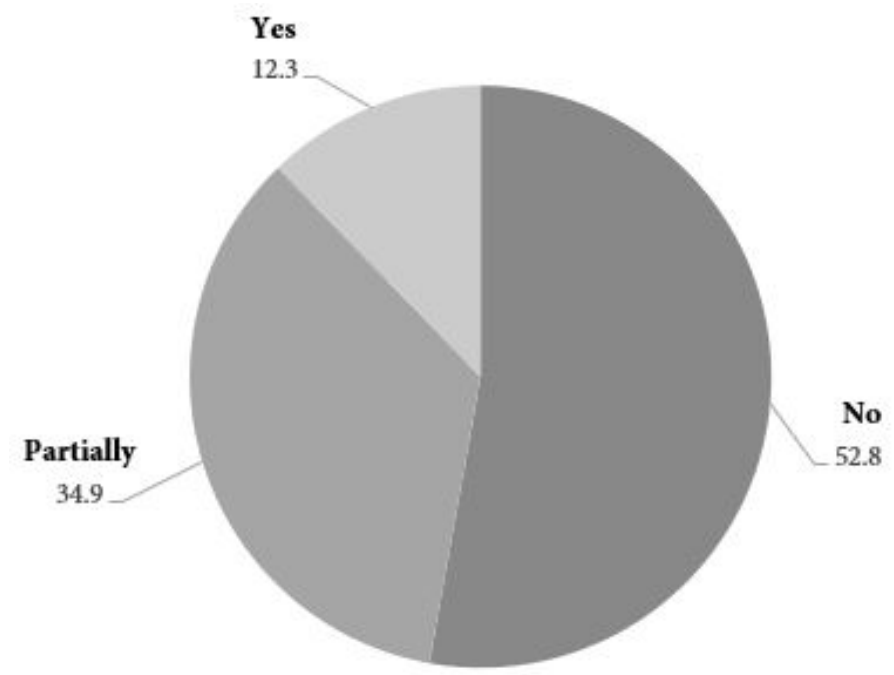

Source: UNL Nebraska Farm Real Estate Market Survey, 2020.

- In Figure 7 panel members indicated $12.3 \%$ of cropland lease provisions were either added or revised to account for risk from flooding or excessive moisture. In addition, 34.9\% reported a partial revise to contractual provisions.

- Over half of the cropland leases did not receive any additional or revised lease terms.

Noticeable changes were reported by panel members in cropland lease provisions to better account for flooding and excessive moisture risk between 2019 and 2020 (Figure 6 and 7). Addressing risk and uncertainty as part of the lease arrangement improves the equitability of the contract for each party involved. Financial risk remains high for landowners and operators. Employing appropriate management strategies to account for risk remains an important feature for designing lease terms and provisions.

\section{References}

USDA-Farm Service Agency (2020a). Marketing Facilitation Payments as of June 22, 2020, retrieved June 24, 2020 from: https://www.farmers.gov/sites/default/files/2020-06/MFP-Data-June-22-20.pdf.

USDA-Farm Service Agency (2020b). Crop Acreage Data Reported to FSA. 2019 Crop Year as of January 1, 2020 retrieved June 22, 2020 from: https://www.fsa.usda.gov/news-room/efoia/electronic-readingroom/frequently-requested-information/crop-acreage-data/index.

USDA-Risk Management Agency (2020). Prevented Planting, retrieved June 18, 2020 from: https://www.rma.usda.gov/en/Topics/PreventedPlanting\#: :text=Prevented\%20planting\%20is\%20a\%20failure,by\%20crop\%20and\%20by\%20area.

USDA-National Agricultural Statistics Service (2019). Table 41. Land Use Practices: 2017 and 2012, retrieved June 16, 2020 from:

https://www.nass.usda.gov/Publications/AgCensus/2017/Full_Report/Volume_1,_Chapter_2_County_ Level/Nebraska/. 
Statistical Appendix 
Appendix Table 1. Farm Real Estate Values in Nebraska, USDA Historical Series, 1860-2020

\begin{tabular}{|c|c|c|c|c|c|c|}
\hline \multirow{2}{*}{ Year } & \multirow{2}{*}{$\begin{array}{l}\text { Number } \\
\text { of Farms }\end{array}$} & \multirow{2}{*}{$\begin{array}{c}\text { Land } \\
\text { in Farms }\end{array}$} & \multicolumn{3}{|c|}{ Value of Land \& Buildings } & \multirow{2}{*}{$\begin{array}{c}\text { Building } \\
\text { Value }\end{array}$} \\
\cline { 4 - 5 } & & Per Acre & Per Farm & Total Value & \\
\hline
\end{tabular}

Thousands Million Acres $\quad \underline{\text { Dollars }} \quad \underline{\text { Thousand Dollars }} \quad \underline{\text { Million Dollars }} \underline{\text { Million Dollars }}$

\begin{tabular}{|c|c|c|c|c|c|c|}
\hline 1860 & 2.8 & 1.0 & 6 & 1.4 & 6 & \\
\hline 1870 & 12.3 & 2.1 & 12 & 2.0 & 24 & \\
\hline 1880 & 63.4 & 9.9 & 11 & 1.7 & 106 & \\
\hline 1890 & 113.6 & 21.6 & 19 & 3.5 & 402 & \\
\hline 1900 & 121.5 & 29.9 & 19 & 4.8 & 578 & 91 \\
\hline 1910 & 129.7 & 38.6 & 47 & 14.0 & 1,813 & 199 \\
\hline 1911 & 129.2 & 39.0 & 48 & 14.4 & 1,864 & \\
\hline 1912 & 128.8 & 39.2 & 49 & 14.9 & 1,919 & \\
\hline 1913 & 128.2 & 39.5 & 50 & 15.4 & 1,974 & \\
\hline 1914 & 127.5 & 39.8 & 51 & 15.9 & 2,027 & \\
\hline 1915 & 126.9 & 40.3 & 50 & 15.9 & 2,017 & \\
\hline 1916 & 126.3 & 40.9 & 51 & 16.5 & 2,084 & \\
\hline 1917 & 125.8 & 41.5 & 54 & 17.8 & 2,240 & \\
\hline 1918 & 125.2 & 41.8 & 62 & 20.7 & 2,591 & \\
\hline 1919 & 123.1 & 41.9 & 71 & 23.8 & 2,978 & \\
\hline 1920 & 124.6 & 42.2 & 88 & 29.8 & 3,712 & 382 \\
\hline 1921 & 125.1 & 41.9 & 82 & 27.5 & 3,439 & \\
\hline 1922 & 137.1 & 41.9 & 71 & 21.7 & 2,974 & \\
\hline 1923 & 126.6 & 42.1 & 68 & 22.6 & 2,860 & \\
\hline 1924 & 127.3 & 41.8 & 63 & 20.7 & 2,635 & 398 \\
\hline 1925 & 127.5 & 42.1 & 60 & 19.8 & 2,524 & \\
\hline 1926 & 128.2 & 42.5 & 60 & 19.9 & 2,552 & \\
\hline 1927 & 128.5 & 43.2 & 58 & 19.5 & 2,505 & \\
\hline 1928 & 128.6 & 44.0 & 57 & 19.5 & 2,508 & \\
\hline 1929 & 128.9 & 44.3 & 57 & 19.6 & 2,526 & \\
\hline 1930 & 129.3 & 44.6 & 56 & 19.3 & 2,495 & 447 \\
\hline 1931 & 129.9 & 45.0 & 52 & 18.0 & 2,338 & \\
\hline 1932 & 130.8 & 45.8 & 44 & 15.4 & 2,015 & \\
\hline 1933 & 132.0 & 46.0 & 35 & 12.2 & 1,609 & \\
\hline 1934 & 133.2 & 46.4 & 35 & 12.2 & 1,625 & \\
\hline 1935 & 134.0 & 46.9 & 34 & 11.9 & 1,594 & 341 \\
\hline 1936 & 131.2 & 46.7 & 34 & 12.1 & 1,587 & \\
\hline 1937 & 128.5 & 47.4 & 32 & 11.8 & 1,516 & \\
\hline 1938 & 125.8 & 47.4 & 30 & 11.3 & 1,421 & \\
\hline 1939 & 123.6 & 46.8 & 28 & 10.6 & 1,310 & \\
\hline 1940 & 121.1 & 47.4 & 24 & 9.4 & 1,138 & 257 \\
\hline 1941 & 119.2 & 48.2 & 22 & 8.9 & 1,061 & \\
\hline 1942 & 116.9 & 48.2 & 24 & 9.9 & 1,157 & \\
\hline 1943 & 115.6 & 47.5 & 27 & 11.1 & 1,283 & \\
\hline 1944 & 113.7 & 47.9 & 33 & 13.9 & 1,580 & \\
\hline
\end{tabular}

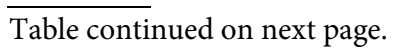


Appendix Table 1. Farm Real Estate Values in Nebraska, USDA Historical Series, 1860-2020 (continued)

\begin{tabular}{|c|c|c|c|c|c|c|}
\hline \multirow{2}{*}{ Year } & \multirow{2}{*}{$\begin{array}{l}\text { Number } \\
\text { of Farms }\end{array}$} & \multirow{2}{*}{$\begin{array}{c}\text { Land } \\
\text { in Farms }\end{array}$} & Per Acre & Per Farm & Total Value & \multirow{2}{*}{$\begin{array}{c}\text { Building } \\
\text { Value }\end{array}$} \\
\cline { 4 - 5 } & &
\end{tabular}

Thousands Million Acres $\quad$ Dollars $\quad$ Thousand Dollars $\quad$ Million Dollars $\quad$ Million Dollars

\begin{tabular}{|c|c|c|c|c|c|c|}
\hline 1945 & 111.4 & 47.6 & 37 & 15.8 & 1,760 & 382 \\
\hline 1946 & 111.3 & 47.4 & 42 & 17.9 & 1,992 & \\
\hline 1947 & 110.1 & 48.0 & 47 & 20.5 & 2,257 & \\
\hline 1947 & 109.0 & 47.3 & 56 & 24.3 & 2,649 & \\
\hline 1949 & 108.0 & 47.2 & 62 & 27.1 & 2,927 & \\
\hline 1950 & 109.0 & 48.4 & 58 & 25.6 & 2,789 & \\
\hline 1951 & 107.0 & 48.4 & 66 & 29.8 & 3,192 & 562 \\
\hline 1952 & 105.0 & 48.3 & 72 & 33.1 & 3,477 & 605 \\
\hline 1953 & 104.0 & 48.3 & 75 & 34.7 & 3,610 & 621 \\
\hline 1954 & 103.0 & 48.3 & 70 & 32.8 & 3,386 & 589 \\
\hline 1955 & 102.0 & 48.3 & 73 & 34.5 & 3,534 & 645 \\
\hline 1956 & 101.0 & 48.3 & 73 & 34.9 & 3,523 & 719 \\
\hline 1957 & 98.0 & 48.3 & 72 & 35.8 & 3,501 & 606 \\
\hline 1958 & 96.0 & 48.3 & 79 & 40.0 & 3,839 & 572 \\
\hline 1959 & 94.0 & 48.3 & 86 & 43.9 & 4,131 & 677 \\
\hline 1960 & 93.0 & 48.2 & 89 & 46.3 & 4,308 & 763 \\
\hline 1961 & 90.0 & 48.2 & 90 & 48.2 & 4,341 & 790 \\
\hline 1962 & 88.0 & 48.2 & 95 & 52.2 & 4,598 & 860 \\
\hline 1963 & 86.0 & 48.1 & 97 & 54.0 & 4,647 & 911 \\
\hline 1964 & 84.0 & 48.2 & 105 & 60.0 & 5,055 & 1,072 \\
\hline 1965 & 82.0 & 48.2 & 111 & 65.3 & 5,352 & 1,258 \\
\hline 1966 & 80.0 & 48.2 & 120 & 72.6 & 5,805 & 1,283 \\
\hline 1967 & 78.0 & 48.2 & 132 & 81.4 & 6,348 & 1,143 \\
\hline 1968 & 76.0 & 48.2 & 143 & 90.5 & 6,882 & 1,136 \\
\hline 1969 & 74.0 & 48.2 & 150 & 97.8 & 7,238 & 1,021 \\
\hline 1970 & 73.0 & 48.1 & 154 & 101.5 & 7,407 & 941 \\
\hline 1971 & 72.0 & 48.1 & 157 & 104.9 & 7,552 & 853 \\
\hline 1972 & 71.0 & 48.1 & 170 & 115.2 & 8,177 & 932 \\
\hline 1973 & 70.0 & 48.1 & 193 & 132.6 & 9,283 & 1,012 \\
\hline 1974 & 70.0 & 48.1 & 242 & 166.3 & 11,640 & 1,152 \\
\hline 1975 & 67.0 & 47.9 & 282 & 201.6 & 13,508 & 1,229 \\
\hline 1976 & 67.0 & 47.9 & 363 & 259.2 & 17,366 & 1,546 \\
\hline 1977 & 66.0 & 47.8 & 420 & 304.1 & 20,070 & 1,806 \\
\hline 1978 & 66.0 & 47.8 & 412 & 298.5 & 19,702 & 1,832 \\
\hline 1979 & 65.0 & 47.7 & 525 & 385.3 & 25,043 & 2,204 \\
\hline 1980 & 65.0 & 47.7 & 635 & 466.0 & 30,289 & 2,547 \\
\hline 1981 & 65.0 & 47.7 & 729 & 535.0 & 34,773 & 2,851 \\
\hline 1982 & 63.0 & 47.5 & 730 & 550.4 & 34,675 & 2,809 \\
\hline 1983 & 62.0 & 47.4 & 701 & 535.9 & 33,227 & 2,758 \\
\hline 1984 & 61.0 & 47.2 & 645 & 499.1 & 30,444 & 2,710 \\
\hline
\end{tabular}

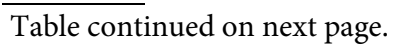


Appendix Table 1. Farm Real Estate Values in Nebraska, USDA Historical Series, 1860-2020 ${ }^{\text {a continued) }}$

\begin{tabular}{|c|c|c|c|c|c|c|}
\hline \multirow{2}{*}{ Year } & \multirow{2}{*}{$\begin{array}{l}\text { Number } \\
\text { of Farms }\end{array}$} & \multirow{2}{*}{$\begin{array}{c}\text { Land } \\
\text { in Farms }\end{array}$} & \multicolumn{3}{|c|}{ Value of Land \& Buildings } & \multirow{2}{*}{$\begin{array}{c}\text { Building } \\
\text { Value }\end{array}$} \\
\hline & & & Per Acre & Per Farm & Total Value & \\
\hline & Thousands & Million Acres & Dollars & Thousand Dollars & Million Dollars & $\underline{\text { Million Dollars }}$ \\
\hline 1985 & 60.0 & 47.2 & 485 & 381.9 & 22,911 & 2,474 \\
\hline 1986 & 59.0 & 47.2 & 416 & 332.7 & 19,629 & 2,532 \\
\hline 1987 & 59.0 & 47.2 & 400 & 320.1 & 18,885 & 2,682 \\
\hline 1988 & 58.0 & 47.1 & 457 & 371.1 & 21,525 & 3,186 \\
\hline 1989 & 57.0 & 47.1 & 511 & 422.2 & 24,068 & 3,451 \\
\hline 1990 & 57.0 & 47.1 & 524 & 433.0 & 24,680 & 3,186 \\
\hline 1991 & 56.0 & 47.1 & 517 & 434.8 & 24,350 & 2,978 \\
\hline 1992 & 56.0 & 47.1 & 517 & 434.8 & 24,350 & 3,026 \\
\hline 1993 & 56.0 & 46.5 & 514 & 426.8 & 23,901 & 3,022 \\
\hline 1994 & 56.0 & 46.5 & 550 & 456.7 & 25,575 & 2,966 \\
\hline 1995 & 56.0 & 46.4 & 580 & 480.6 & 26,912 & 3,041 \\
\hline 1996 & 56.0 & 46.4 & 610 & 505.4 & 28,304 & 3,099 \\
\hline 1997 & 55.0 & 46.4 & 620 & 523.1 & 28,768 & 3,049 \\
\hline 1998 & 55.0 & 46.4 & 645 & 544.1 & 29,928 & 3,068 \\
\hline 1999 & 54.0 & 46.3 & 675 & 578.8 & 31,253 & 3,094 \\
\hline 2000 & 52.0 & 46.1 & 710 & 629.4 & 32,731 & 3,126 \\
\hline 2001 & 50.0 & 46.0 & 735 & 676.2 & 33,810 & 3,111 \\
\hline 2002 & 49.4 & 45.9 & 760 & 706.2 & 34,884 & 3,087 \\
\hline 2003 & 48.5 & 45.9 & 775 & 733.5 & 35,573 & 3,024 \\
\hline 2004 & 48.3 & 45.8 & 810 & 768.1 & 37,098 & 3,023 \\
\hline 2005 & 48.0 & 45.7 & 910 & 866.4 & 41,587 & 3,168 \\
\hline 2006 & 47.6 & 45.7 & 1,030 & 988.9 & 47,071 & 3,507 \\
\hline 2007 & 47.7 & 45.6 & 1,140 & $1,089.8$ & 51,984 & 3,681 \\
\hline 2008 & 48.2 & 45.5 & 1,330 & $1,255.5$ & 60,515 & 3,909 \\
\hline 2009 & 48.6 & 45.5 & 1,320 & $1,235.8$ & 60,060 & 4,264 \\
\hline 2010 & 49.5 & 45.4 & 1,470 & $1,348.2$ & 66,738 & 4,738 \\
\hline 2011 & 49.7 & 45.4 & 1,840 & $1,680.8$ & 83,536 & 5,847 \\
\hline 2012 & 50.0 & 45.3 & 2,420 & $2,192.5$ & 109,626 & 7,674 \\
\hline 2013 & 49.4 & 45.3 & 2,800 & $2,567.6$ & 126,840 & 8,816 \\
\hline 2014 & 48.7 & 45.1 & 3,100 & $2,870.8$ & 139,810 & 9,647 \\
\hline 2015 & 48.0 & 45.1 & 3,010 & $2,828.1$ & 135,751 & 9,910 \\
\hline 2016 & 47.5 & 45.0 & 2,890 & $2,737.9$ & 130,050 & 9,332 \\
\hline 2017 & 46.3 & 45.0 & 2,820 & $2,740.8$ & 126,900 & 9,003 \\
\hline 2018 & 45.9 & 45.0 & 2,750 & $2,696.1$ & 123,750 & 8,725 \\
\hline 2019 & 45.7 & 44.9 & 2,850 & $2,800.1$ & 127,965 & 8,980 \\
\hline $2020^{b}$ & 45.7 & 44.9 & 2,936 & $2,884.8$ & 131,835 & 9,245 \\
\hline
\end{tabular}


Appendix Table 2. Deflated USDA Farmland Values and Percent Changes for Nebraska, 1930 to $2020^{\mathrm{a}}$

\begin{tabular}{|c|c|c|c|c|}
\hline Year & $\begin{array}{c}\text { USDA Average } \\
\text { Value/Acre For Nebraska }\end{array}$ & $\begin{array}{c}1^{\text {st }} \text { Quarter GDP } \\
\text { Price Deflator } \\
(2020=100)\end{array}$ & $\begin{array}{l}\text { Deflated Average } \\
\text { Value/Acre }\end{array}$ & $\begin{array}{c}\text { Year-to-Year Change } \\
\text { Deflated Farmland in } \\
\text { Values }^{c}\end{array}$ \\
\hline 1930 & 56 & 7.86 & 712 & - \\
\hline 1931 & 52 & 7.05 & 737 & 3.5 \\
\hline 1932 & 44 & 6.22 & 707 & -4.1 \\
\hline 1933 & 35 & 6.05 & 579 & -18.2 \\
\hline 1934 & 35 & 6.39 & 548 & -5.3 \\
\hline 1935 & 34 & 6.52 & 522 & -4.8 \\
\hline 1936 & 34 & 6.59 & 516 & -1.1 \\
\hline 1937 & 32 & 6.88 & 465 & -9.8 \\
\hline 1938 & 30 & 6.68 & 449 & -3.4 \\
\hline 1939 & 28 & 6.61 & 423 & -5.8 \\
\hline 1940 & 24 & 6.69 & 359 & -15.2 \\
\hline 1941 & 22 & 7.13 & 308 & -14.0 \\
\hline 1942 & 24 & 7.69 & 312 & 1.2 \\
\hline 1943 & 27 & 8.11 & 333 & 6.7 \\
\hline 1944 & 33 & 8.30 & 398 & 19.4 \\
\hline 1945 & 37 & 8.52 & 434 & 9.2 \\
\hline 1946 & 42 & 9.54 & 440 & 1.3 \\
\hline 1947 & 47 & 10.54 & 446 & 1.3 \\
\hline 1948 & 56 & 11.22 & 499 & 11.9 \\
\hline 1949 & 62 & 11.32 & 547 & 9.7 \\
\hline 1950 & 58 & 11.51 & 504 & -7.9 \\
\hline 1951 & 66 & 12.26 & 539 & 6.9 \\
\hline 1952 & 72 & 12.48 & 577 & 7.1 \\
\hline 1953 & 75 & 12.67 & 592 & 2.6 \\
\hline 1954 & 70 & 12.81 & 546 & -7.7 \\
\hline 1955 & 73 & 12.94 & 564 & 3.3 \\
\hline 1956 & 73 & 13.34 & 547 & -3.0 \\
\hline 1957 & 72 & 13.83 & 520 & -4.9 \\
\hline 1958 & 79 & 14.17 & 557 & 7.1 \\
\hline 1959 & 86 & 14.40 & 597 & 7.1 \\
\hline 1960 & 89 & 14.60 & 610 & 2.1 \\
\hline 1961 & 90 & 14.76 & 610 & 0.0 \\
\hline 1962 & 95 & 14.95 & 635 & 4.2 \\
\hline 1963 & 97 & 15.11 & 642 & 1.1 \\
\hline 1964 & 105 & 15.32 & 685 & 6.7 \\
\hline 1965 & 111 & 15.57 & 713 & 4.1 \\
\hline 1966 & 120 & 15.91 & 754 & 5.8 \\
\hline 1967 & 132 & 16.40 & 805 & 6.7 \\
\hline 1968 & 143 & 17.01 & 841 & 4.4 \\
\hline 1969 & 150 & 17.79 & 843 & 0.3 \\
\hline
\end{tabular}

Table continued on next page. 
Appendix Table 2. Deflated USDA Farmland Values and Percent Changes for Nebraska, 1930 to $2020^{a}$ (continued)

\begin{tabular}{|c|c|c|c|c|}
\hline Year & $\begin{array}{c}\text { USDA Average } \\
\text { Value/Acre For Nebraska }\end{array}$ & $\begin{array}{c}1^{\text {st }} \text { Quarter GDP } \\
\text { Price Deflator } \\
(2020=100)\end{array}$ & $\begin{array}{l}\text { Deflated Average } \\
\text { Value/Acre }\end{array}$ & $\begin{array}{c}\text { Year-to-Year Change } \\
\text { Deflated Farmland in } \\
\text { Values }\end{array}$ \\
\hline 1970 & 154 & 18.76 & 821 & -2.7 \\
\hline 1971 & 157 & 19.73 & 796 & -3.0 \\
\hline 1972 & 170 & 20.67 & 822 & 3.4 \\
\hline 1973 & 193 & 21.51 & 897 & 9.1 \\
\hline 1974 & 242 & 23.14 & 1,046 & 16.6 \\
\hline 1975 & 282 & 25.67 & 1,099 & 5.1 \\
\hline 1976 & 363 & 27.24 & 1,333 & 21.3 \\
\hline 1977 & 420 & 28.82 & 1,457 & 9.3 \\
\hline 1978 & 412 & 30.66 & 1,344 & -7.8 \\
\hline 1979 & 525 & 33.02 & 1,590 & 18.3 \\
\hline 1980 & 635 & 35.95 & 1,766 & 11.1 \\
\hline 1981 & 729 & 39.63 & 1,840 & 4.2 \\
\hline 1982 & 730 & 42.46 & 1,719 & -6.5 \\
\hline 1983 & 701 & 44.41 & 1,579 & -8.2 \\
\hline 1984 & 645 & 46.01 & 1,402 & -11.2 \\
\hline 1985 & 485 & 47.64 & 1,018 & -27.4 \\
\hline 1986 & 416 & 48.74 & 853 & -16.2 \\
\hline 1987 & 400 & 49.71 & 805 & -5.7 \\
\hline 1988 & 457 & 51.23 & 892 & 10.9 \\
\hline 1989 & 511 & 53.35 & 958 & 7.4 \\
\hline 1990 & 524 & 55.29 & 948 & -1.1 \\
\hline 1991 & 517 & 57.37 & 901 & -4.9 \\
\hline 1992 & 517 & 58.80 & 879 & -2.4 \\
\hline 1993 & 514 & 60.19 & 854 & -2.9 \\
\hline 1994 & 550 & 61.53 & 894 & 4.7 \\
\hline 1995 & 580 & 62.86 & 923 & 3.2 \\
\hline 1996 & 610 & 64.09 & 952 & 3.2 \\
\hline 1997 & 620 & 65.30 & 950 & -0.2 \\
\hline 1998 & 645 & 66.02 & 977 & 2.9 \\
\hline 1999 & 675 & 66.90 & 1,009 & 3.3 \\
\hline 2000 & 710 & 68.19 & 1,041 & 3.2 \\
\hline 2001 & 735 & 69.79 & 1,053 & 1.2 \\
\hline 2002 & 760 & 70.96 & 1,071 & 1.7 \\
\hline 2003 & 775 & 72.27 & 1,072 & 0.1 \\
\hline 2004 & 810 & 73.85 & 1,097 & 2.3 \\
\hline 2005 & 910 & 76.12 & 1,195 & 9.0 \\
\hline 2006 & 1,030 & 78.51 & 1,312 & 9.7 \\
\hline 2007 & 1,140 & 80.80 & 1,411 & 7.5 \\
\hline 2008 & 1,330 & 82.37 & 1,615 & 14.4 \\
\hline 2009 & 1,320 & 83.68 & 1,577 & -2.3 \\
\hline
\end{tabular}

$\overline{\text { Table continued }}$ on next page. 
Appendix Table 2. Deflated USDA Farmland Values and Percent Changes for Nebraska, 1930 to $2020^{a}$ (continued)

\begin{tabular}{|c|c|c|c|c|}
\hline Year & $\begin{array}{c}\text { USDA Average } \\
\text { Value/Acre For Nebraska }\end{array}$ & $\begin{array}{c}1^{\text {st }} \text { Quarter GDP } \\
\text { Price Deflator } \\
(2020=100)\end{array}$ & $\begin{array}{l}\text { Deflated Average } \\
\text { Value/Acre }\end{array}$ & $\begin{array}{c}\text { Year-to-Year Change } \\
\text { Deflated Farmland in } \\
\text { Values }\end{array}$ \\
\hline 2010 & 1,470 & 84.15 & 1,747 & 10.8 \\
\hline 2011 & 1,840 & 85.72 & 2,147 & 22.9 \\
\hline 2012 & 2,420 & 88.11 & 2,747 & 27.9 \\
\hline 2013 & 2,800 & 89.11 & 3,142 & 14.4 \\
\hline 2014 & 3,100 & 90.70 & 3,418 & 8.8 \\
\hline 2015 & 3,010 & 91.71 & 3,282 & -4.0 \\
\hline 2016 & 2,890 & 92.46 & 3,126 & -4.8 \\
\hline 2017 & 2,820 & 94.33 & 2,990 & -4.4 \\
\hline 2018 & 2,750 & 96.35 & 2,854 & -4.5 \\
\hline 2019 & 2,850 & 98.22 & 2,902 & 1.7 \\
\hline $2020^{d}$ & 2,936 & 100.00 & 2,936 & 1.2 \\
\hline
\end{tabular}

Source: ${ }^{a}$ Revised from series reported in earlier reports. Refers to year ending March 1 for years prior to 1976; year ending February 1 for years 1976-1981; year ending April 1 for years 1982-1985; year ending February 1 for years 1986-1989; year ending January 1 for years 1990-1994; mid-year 1995-1997, and year ending January 1, 2000.

${ }^{\mathrm{b}}$ Computed by dividing the USDA average value per acre by the 1st Quarter GDP Price Deflator $(2020=100)$ and multiplying by 100 .

${ }^{c}$ A positive value entry in this column represents a real increase in asset value for the year (i.e., the rate of land value appreciation exceeded the general rate of inflation for the U.S. economy). Conversely, a negative value entry represents a real decrease in asset value.

d Preliminary. 
Appendix Table 3. Nominal and Deflated Agricultural Land Values by Selected Types of Land in Nebraska, 1978 to $2020^{a}$

\begin{tabular}{|c|c|c|c|c|c|c|c|c|c|}
\hline \multirow[b]{2}{*}{ Year } & \multicolumn{4}{|c|}{ Nominal Value/Acre ${ }^{a}$} & \multirow{2}{*}{$\begin{array}{c}1^{\text {st }} \text { Quarter } \\
\text { GDP Price } \\
\text { Deflator } \\
(2020=100)\end{array}$} & \multicolumn{4}{|c|}{ Deflated Value/Acre $^{\mathrm{b}}$} \\
\hline & $\begin{array}{l}\text { Dryland } \\
\text { Cropland }\end{array}$ & $\begin{array}{c}\text { Center Pivot } \\
\text { Irrigated } \\
\text { Cropland }^{\mathfrak{c}}\end{array}$ & $\begin{array}{c}\text { Grazing } \\
\text { Land } \\
\text { (Nontillable) } \\
\end{array}$ & $\begin{array}{l}\text { All-Land } \\
\text { Average }\end{array}$ & & $\begin{array}{l}\text { Dryland } \\
\text { Cropland }\end{array}$ & $\begin{array}{c}\text { Center Pivot } \\
\text { Irrigated } \\
\text { Cropland }^{\mathfrak{c}}\end{array}$ & $\begin{array}{c}\text { Grazing } \\
\text { Land } \\
\text { (Nontillable) }\end{array}$ & $\begin{array}{l}\text { All-Land } \\
\text { Average }^{\mathrm{d}}\end{array}$ \\
\hline & \multicolumn{4}{|c|}{ 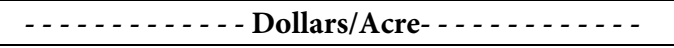 } & & \multicolumn{4}{|c|}{ 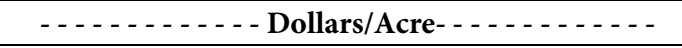 } \\
\hline 1978 & 466 & 1,015 & 151 & 489 & 30.66 & 1,520 & 3,310 & 492 & 1,595 \\
\hline 1979 & 562 & 1,201 & 185 & 584 & 33.02 & 1,702 & 3,637 & 560 & 1,769 \\
\hline 1980 & 655 & 1,384 & 207 & 677 & 35.95 & 1,822 & 3,850 & 576 & 1,883 \\
\hline 1981 & 734 & 1,470 & 228 & 729 & 39.63 & 1,852 & 3,710 & 575 & 1,840 \\
\hline 1982 & 701 & 1,410 & 225 & 701 & 42.46 & 1,651 & 3,321 & 530 & 1,651 \\
\hline 1983 & 644 & 1,222 & 204 & 621 & 44.41 & 1,450 & 2,752 & 459 & 1,398 \\
\hline 1984 & 600 & 1,143 & 183 & 574 & 46.01 & 1,304 & 2,484 & 398 & 1,247 \\
\hline 1985 & 497 & 899 & 134 & 466 & 47.64 & 1,043 & 1,887 & 281 & 978 \\
\hline 1986 & 367 & 689 & 97 & 335 & 48.74 & 753 & 1,414 & 199 & 687 \\
\hline 1987 & 353 & 626 & 82 & 302 & 49.71 & 710 & 1,259 & 165 & 608 \\
\hline 1988 & 395 & 718 & 90 & 342 & 51.23 & 771 & 1,401 & 176 & 668 \\
\hline 1989 & 474 & 910 & 122 & 428 & 53.35 & 888 & 1,706 & 229 & 802 \\
\hline 1990 & 503 & 1,003 & 144 & 470 & 55.29 & 910 & 1,814 & 260 & 850 \\
\hline 1991 & 506 & 1,060 & 157 & 490 & 57.37 & 882 & 1,848 & 274 & 854 \\
\hline 1992 & 518 & 1,089 & 163 & 506 & 58.80 & 881 & 1,852 & 277 & 860 \\
\hline 1993 & 540 & 1,140 & 169 & 528 & 60.19 & 897 & 1,894 & 281 & 877 \\
\hline 1994 & 571 & 1,206 & 181 & 563 & 61.53 & 928 & 1,960 & 294 & 915 \\
\hline 1995 & 584 & 1,254 & 189 & 581 & 62.86 & 929 & 1,995 & 301 & 924 \\
\hline 1996 & 615 & 1,342 & 186 & 608 & 64.09 & 990 & 2,094 & 290 & 949 \\
\hline 1997 & 659 & 1,465 & 200 & 657 & 65.30 & 1,009 & 2,244 & 306 & 1,006 \\
\hline 1998 & 713 & 1,614 & 221 & 716 & 66.02 & 1,080 & 2,445 & 335 & 1,084 \\
\hline 1999 & 693 & 1,568 & 216 & 697 & 66.90 & 1,036 & 2,344 & 323 & 1,042 \\
\hline 2000 & 695 & 1,600 & 228 & 707 & 68.19 & 1,019 & 2,346 & 334 & 1,037 \\
\hline 2001 & 699 & 1,608 & 240 & 719 & 69.79 & 1,002 & 2,304 & 344 & 1,030 \\
\hline 2002 & 733 & 1,660 & 250 & 746 & 70.96 & 1,033 & 2,339 & 352 & 1,051 \\
\hline 2003 & 741 & 1,679 & 250 & 756 & 72.27 & 1,025 & 2,323 & 346 & 1,046 \\
\hline 2004 & 808 & 1,833 & 275 & 824 & 73.85 & 1,094 & 2,482 & 372 & 1,116 \\
\hline 2005 & 908 & 2,045 & 317 & 914 & 76.12 & 1,193 & 2,687 & 416 & 1,201 \\
\hline 2006 & 1,008 & 2,197 & 353 & 1,001 & 78.51 & 1,284 & 2,798 & 450 & 1,275 \\
\hline 2007 & 1,153 & 2,509 & 402 & 1,145 & 80.80 & 1,427 & 3,105 & 497 & 1,417 \\
\hline 2008 & 1,457 & 3,157 & 451 & 1,414 & 82.37 & 1,769 & 3,833 & 548 & 1,717 \\
\hline 2009 & 1,441 & 3,304 & 449 & 1,431 & 83.68 & 1,722 & 3,948 & 537 & 1,710 \\
\hline
\end{tabular}

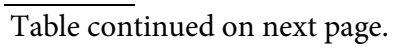


Appendix Table 3. Nominal and Deflated Agricultural Land Values by Selected Types of Land in Nebraska, 1978 to $2020^{\text {a }}$ (continued)

\begin{tabular}{|c|c|c|c|c|c|c|c|c|c|}
\hline \multirow[b]{2}{*}{ Year } & \multicolumn{4}{|c|}{ Nominal Value/Acre $^{\mathrm{a}}$} & \multirow{2}{*}{$\begin{array}{l}1^{\text {st }} \text { Quarter } \\
\text { GDP Price } \\
\text { Deflator } \\
(2020=100)\end{array}$} & \multicolumn{4}{|c|}{ Deflated Value/Acre $^{\mathrm{b}}$} \\
\hline & $\begin{array}{l}\text { Dryland } \\
\text { Cropland }\end{array}$ & $\begin{array}{c}\text { Center Pivot } \\
\text { Irrigated } \\
\text { Cropland }^{c}\end{array}$ & $\begin{array}{c}\text { Grazing } \\
\text { Land } \\
\text { (Nontillable) }\end{array}$ & $\begin{array}{l}\text { All-Land } \\
\text { Average }\end{array}$ & & $\begin{array}{l}\text { Dryland } \\
\text { Cropland }\end{array}$ & $\begin{array}{c}\text { Center Pivot } \\
\text { Irrigated } \\
\text { Cropland }^{c}\end{array}$ & $\begin{array}{c}\text { Grazing } \\
\text { Land } \\
\text { (Nontillable) }\end{array}$ & $\begin{array}{l}\text { All-Land } \\
\text { Average }^{\mathrm{d}}\end{array}$ \\
\hline & \multicolumn{4}{|c|}{ 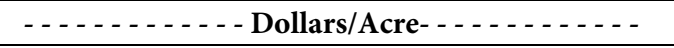 } & & \multicolumn{4}{|c|}{ - - - - - - - - - Dollars/Acre- - - - - - - - - - } \\
\hline 2010 & 1,530 & 3,520 & 425 & 1,503 & 84.15 & 1,818 & 4,183 & 505 & 1,786 \\
\hline 2011 & 1,850 & 4,343 & 490 & 1,833 & 85.72 & 2,158 & 5,067 & 572 & 2,138 \\
\hline 2012 & 2,585 & 5,835 & 585 & 2,425 & 88.11 & 2,934 & 6,622 & 664 & 2,752 \\
\hline 2013 & 3,365 & 7,430 & 695 & 3,045 & 89.11 & 4,186 & 8,624 & 971 & 3,720 \\
\hline 2014 & 3,730 & 7,685 & 865 & 3,315 & 90.70 & 4,113 & 8,473 & 954 & 3,655 \\
\hline 2015 & 3,390 & 7,315 & 1,005 & 3,250 & 91.71 & 3,696 & 7,976 & 1,096 & 3,544 \\
\hline 2016 & 3,470 & 6,940 & 975 & 3,115 & 92.46 & 3,753 & 7,506 & 1,054 & 3,369 \\
\hline 2017 & 3,145 & 6,295 & 895 & 2,820 & 94.33 & 3,334 & 6,673 & 949 & 2,990 \\
\hline 2018 & 3,100 & 6,130 & 835 & 2,720 & 96.35 & 3,217 & 6,362 & 867 & 2,823 \\
\hline 2019 & 3,040 & 5,970 & 795 & 2,645 & 98.22 & 3,095 & 6,078 & 809 & 2,693 \\
\hline 2020 & 3,165 & 6,125 & 830 & 2,725 & 100.00 & 3,165 & 6,125 & 830 & 2,725 \\
\hline
\end{tabular}

Source: a Annual February 1, estimates reported in the UNL Nebraska Farm Real Estate Market Surveys, 1978-2020: revised series, June 2009.

${ }^{\mathrm{b}}$ Computed by dividing USDA average value per acre by the 1 st Quarter GDP Price Deflator $(2020=100)$ and multiplying by 100.

${ }^{c}$ Pivot not included in per acre value.

${ }^{\mathrm{d}}$ Deflated all-land average based on the UNL Nebraska Farm Real Estate Market Surveys and will not correspond directly with the USDA series presented in Appendix Table 2. 
Appendix Table 4. Average Reported Value of Nebraska Farmland for Different Types of Land by Agricultural Statistics District, 1978-2020a

\begin{tabular}{|c|c|c|c|c|c|c|c|c|c|}
\hline \multirow{2}{*}{ Year } & \multicolumn{7}{|c|}{ Agricultural Statistics District } \\
\cline { 2 - 8 } & Northwest & North & Northeast & Central & East & Southwest & South & Southeast $^{\text {State }}{ }^{\text {b }}$ \\
\hline
\end{tabular}

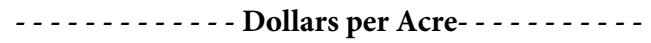

Dryland Cropland (No Irrigation Potential)

\begin{tabular}{|c|c|c|c|c|c|c|c|c|c|}
\hline 1978 & 289 & 253 & 648 & 319 & 817 & 360 & 468 & 660 & 466 \\
\hline 1979 & 317 & 319 & 813 & 397 & 1,061 & 387 & 541 & 808 & 562 \\
\hline 1980 & 347 & 340 & 920 & 471 & 1,296 & 454 & 626 & 971 & 655 \\
\hline 1981 & 419 & 346 & 1,009 & 519 & 1,409 & 546 & 754 & 1,060 & 734 \\
\hline 1982 & 411 & 335 & 966 & 502 & 1,325 & 522 & 752 & 988 & 701 \\
\hline 1983 & 387 & 321 & 864 & 450 & 1,204 & 469 & 664 & 939 & 644 \\
\hline 1984 & 379 & 300 & 779 & 416 & 1,128 & 444 & 653 & 840 & 600 \\
\hline 1985 & 325 & 237 & 643 & 340 & 905 & 365 & 474 & 612 & 497 \\
\hline 1986 & 259 & 198 & 499 & 263 & 669 & 308 & 412 & 423 & 367 \\
\hline 1987 & 242 & 190 & 520 & 246 & 626 & 288 & 377 & 416 & 353 \\
\hline 1988 & 267 & 202 & 576 & 301 & 692 & 294 & 411 & 513 & 395 \\
\hline 1989 & 305 & 250 & 688 & 370 & 824 & 371 & 491 & 621 & 474 \\
\hline 1990 & 309 & 279 & 728 & 407 & 877 & 409 & 491 & 662 & 503 \\
\hline 1991 & 316 & 279 & 735 & 463 & 885 & 380 & 508 & 655 & 506 \\
\hline 1992 & 340 & 295 & 700 & 418 & 955 & 386 & 513 & 673 & 518 \\
\hline 1993 & 337 & 288 & 766 & 486 & 1,000 & 373 & 573 & 701 & 540 \\
\hline 1994 & 345 & 314 & 797 & 504 & 1,090 & 390 & 620 & 741 & 571 \\
\hline 1995 & 335 & 320 & 803 & 519 & 1,144 & 403 & 637 & 764 & 584 \\
\hline 1996 & 358 & 338 & 823 & 535 & 1,244 & 419 & 658 & 799 & 615 \\
\hline 1997 & 381 & 363 & 909 & 588 & 1,336 & 432 & 701 & 852 & 659 \\
\hline 1998 & 385 & 390 & 982 & 631 & 1,477 & 457 & 753 & 956 & 713 \\
\hline 1999 & 346 & 367 & 968 & 635 & 1,462 & 428 & 740 & 953 & 693 \\
\hline 2000 & 331 & 400 & 970 & 648 & 1,464 & 434 & 708 & 958 & 695 \\
\hline 2001 & 319 & 403 & 996 & 645 & 1,493 & 433 & 725 & 954 & 699 \\
\hline 2002 & 325 & 407 & 1,095 & 680 & 1,523 & 460 & 743 & 1,024 & 733 \\
\hline 2003 & 319 & 360 & 1,107 & 710 & 1,585 & 453 & 748 & 1,059 & 741 \\
\hline 2004 & 328 & 416 & 1,231 & 758 & 1,717 & 473 & 800 & 1,190 & 808 \\
\hline 2005 & 330 & 447 & 1,382 & 847 & 2,024 & 495 & 864 & 1,396 & 908 \\
\hline 2006 & 348 & 483 & 1,641 & 933 & 2,276 & 519 & 875 & 1,563 & 1,008 \\
\hline 2007 & 383 & 558 & 1,917 & 1,056 & 2,608 & 559 & 932 & 1,840 & 1,153 \\
\hline 2008 & 460 & 707 & 2,482 & 1,347 & 3,203 & 693 & 1,241 & 2,367 & 1,457 \\
\hline 2009 & 464 & 692 & 2,498 & 1,300 & 3,101 & 696 & 1,318 & 2,297 & 1,441 \\
\hline
\end{tabular}

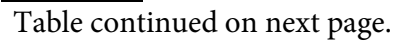


Appendix Table 4. Average Reported Value of Nebraska Farmland for Different Types of Land by Agricultural Statistics District, 1978-2020 ${ }^{a}$ (continued)

\begin{tabular}{|c|c|c|c|c|c|c|c|c|c|}
\hline \multirow{2}{*}{ Year } & \multicolumn{9}{|c|}{ Agricultural Statistics District } \\
\hline & Northwest & North & Northeast & Central & East & Southwest & South & Southeast & State $^{b}$ \\
\hline
\end{tabular}

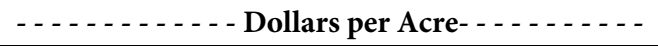

Dryland Cropland (No Irrigation Potential)

$\begin{array}{lrrrrrrrrr}\mathbf{2 0 1 0} & 475 & 715 & 2,740 & 1,365 & 3,330 & 735 & 1,380 & 2,410 & 1,530 \\ \mathbf{2 0 1 1} & 545 & 800 & 3,450 & 1,605 & 3,995 & 875 & 1,738 & 2,925 & 1,850 \\ \mathbf{2 0 1 2} & 660 & 1,050 & 4,740 & 2,170 & 5,385 & 1,250 & 2,250 & 3,800 & 2,485 \\ \mathbf{2 0 1 3} & 700 & 1,155 & 5,995 & 2,625 & 6,730 & 1,530 & 3,240 & 4,925 \\ \mathbf{2 0 1 4} & 845 & 1,720 & 6,430 & 3,490 & 6,575 & 1,965 & 3,490 & 5,425 & 3,010 \\ \mathbf{2 0 1 5} & 730 & 1,580 & 5,645 & 3,115 & 5,980 & 1,855 & 3,340 & 5,060 \\ \mathbf{2 0 1 6} & 745 & 1,650 & 5,760 & 3,235 & 6,360 & 1,955 & 3,575 & 4,845 & 3,390 \\ \mathbf{2 0 1 7} & 715 & 1,560 & 5,410 & 2,785 & 5,790 & 1,710 & 3,045 & 4,285 \\ \mathbf{2 0 1 8} & 670 & 1,515 & 5,530 & 2,720 & 5,675 & 1,585 & 2,965 & 4,205 \\ \mathbf{2 0 1 9} & 645 & 1,495 & 5,300 & 2,755 & 5,765 & 1,445 & 2,880 & 4,130 & 3,100 \\ & & & & & & & & 3,040 \\ \mathbf{2 0 2 0} & 610 & 1,515 & 5,495 & 2,845 & 6,120 & 1,415 & 2,980 & 4,435\end{array}$

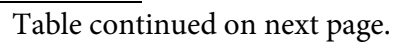


Appendix Table 4. Average Reported Value of Nebraska Farmland for Different Types of Land by Agricultural Statistics District, 1978-2020 ${ }^{a}$ (continued)

\begin{tabular}{|c|c|c|c|c|c|c|c|c|c|}
\hline \multirow{2}{*}{ Year } & \multicolumn{7}{|c|}{ Agricultural Statistics District } \\
\cline { 2 - 9 } & Northwest & North & Northeast & Central & East & Southwest & South & Southeast & State ${ }^{\mathbf{b}}$ \\
\hline
\end{tabular}

. . . . . . . . . . - Dollars per Acre- . . . . . . . . . .

Dryland Cropland (Irrigation Potential)

\begin{tabular}{|c|c|c|c|c|c|c|c|c|c|}
\hline 1978 & 409 & 387 & 741 & 590 & 128 & 471 & 873 & 953 & 757 \\
\hline 1979 & 449 & 514 & 930 & 708 & 1,411 & 520 & 1,102 & 1,152 & 926 \\
\hline 1980 & 533 & 565 & 1,132 & 767 & 1,733 & 628 & 1,282 & 1,352 & 1,147 \\
\hline 1981 & 680 & 533 & 1,225 & 880 & 1,785 & 733 & 1,432 & 1,402 & 1,223 \\
\hline 1982 & 658 & 535 & 1,097 & 833 & 1,665 & 685 & 1,411 & 1,268 & 1,132 \\
\hline 1983 & 563 & 462 & 975 & 680 & 1,462 & 654 & 1,175 & 1,160 & 1,002 \\
\hline 1984 & 507 & 441 & 911 & 638 & 1,349 & 631 & 1,050 & 1,069 & 929 \\
\hline 1985 & 425 & 340 & 746 & 486 & 1,013 & 504 & 705 & 723 & 708 \\
\hline 1986 & 312 & 300 & 598 & 367 & 746 & 377 & 573 & 545 & 542 \\
\hline 1987 & 285 & 250 & 567 & 325 & 707 & 328 & 503 & 508 & 504 \\
\hline 1988 & 310 & 266 & 646 & 380 & 801 & 339 & 576 & 623 & 574 \\
\hline 1989 & 376 & 339 & 773 & 483 & 980 & 433 & 684 & 772 & 702 \\
\hline 1990 & 371 & 367 & 840 & 539 & 1,056 & 473 & 706 & 816 & 752 \\
\hline 1991 & 396 & 360 & 817 & 604 & 1,083 & 478 & 756 & 777 & 754 \\
\hline 1992 & 411 & 381 & 823 & 658 & 1,124 & 476 & 792 & 835 & 781 \\
\hline 1993 & 419 & 400 & 884 & 678 & 1,195 & 445 & 883 & 888 & 825 \\
\hline 1994 & 430 & 436 & 962 & 739 & 1,338 & 482 & 923 & 936 & 899 \\
\hline 1995 & 429 & 424 & 1,002 & 781 & 1,397 & 493 & 941 & 979 & 932 \\
\hline 1996 & 441 & 444 & 1,040 & 845 & 1,525 & 508 & 1,008 & 1,046 & 992 \\
\hline 1997 & 458 & 475 & 1,103 & 917 & 1,643 & 543 & 1,114 & 1,130 & 1,064 \\
\hline 1998 & 482 & 510 & 1,219 & 986 & 1,810 & 578 & 1,216 & 1,250 & 1,167 \\
\hline 1999 & 436 & 480 & 1,216 & 956 & 1,792 & 538 & 1,173 & 1,172 & 1,137 \\
\hline 2000 & 418 & 492 & 1,220 & 951 & 1,800 & 546 & 1,112 & 1,187 & 1,140 \\
\hline 2001 & 409 & 500 & 1,256 & 981 & 1,807 & 572 & 1,126 & 1,234 & 1,161 \\
\hline 2002 & 418 & 514 & 1,355 & 1,020 & 1,814 & 581 & 1,145 & 1,318 & 1,205 \\
\hline 2003 & 396 & 480 & 1,410 & 1,095 & 1,930 & 558 & 1,118 & 1,290 & 1,240 \\
\hline 2004 & 445 & 534 & 1,554 & 1,137 & 2,093 & 586 & 1,217 & 1,469 & 1,360 \\
\hline 2005 & 450 & 579 & 1,696 & 1,286 & 2,395 & 606 & 1,330 & 1,642 & 1,513 \\
\hline 2006 & 455 & 650 & 1,931 & 1,450 & 2,642 & 623 & 1,229 & 1,854 & 1,677 \\
\hline 2007 & 490 & 808 & 2,407 & 1,564 & 2,900 & 702 & 1,126 & 2,150 & 1,931 \\
\hline 2008 & 505 & 1,035 & 3,145 & 1,894 & 3,691 & 716 & 1,301 & 2,700 & 2,440 \\
\hline 2009 & 500 & 1,008 & 3,000 & 1,818 & 3,558 & 750 & 1,415 & 2,982 & 2,411 \\
\hline
\end{tabular}

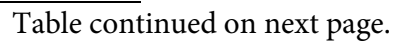


Appendix Table 4. Average Reported Value of Nebraska Farmland for Different Types of Land by Agricultural Statistics District, $1978-2020^{a}$ (continued)

\begin{tabular}{|c|c|c|c|c|c|c|c|c|c|}
\hline \multirow{2}{*}{ Year } & \multicolumn{9}{|c|}{ Agricultural Statistics District } \\
\hline & Northwest & North & Northeast & Central & East & Southwest & South & Southeast & State $^{b}$ \\
\hline
\end{tabular}

Dryland Cropland (Irrigation Potential)

\begin{tabular}{|c|c|c|c|c|c|c|c|c|c|}
\hline 2010 & 515 & 1,095 & 3,280 & 1,910 & 3,995 & 775 & 1,535 & 2,995 & 2,611 \\
\hline 2011 & 550 & 1,200 & 4,200 & 2,355 & 4,765 & 905 & 2,090 & 3,640 & 3,192 \\
\hline 2012 & 680 & 1,625 & 5,800 & 3,360 & 6,390 & 1,275 & 2,945 & 5,035 & 4,355 \\
\hline 2013 & 730 & 1,920 & 7,050 & 3,945 & 7,400 & 1,655 & 4,175 & 6,590 & 5,270 \\
\hline 2014 & 935 & 2,390 & 7,215 & 4,910 & 7,545 & 2,035 & 5,090 & 7,100 & 5,240 \\
\hline 2015 & 870 & 2,290 & 7,065 & 4,095 & 7,310 & 1,950 & 4,510 & 6,940 & 5,030 \\
\hline 2016 & 790 & 2,150 & 6,715 & 3,850 & 7,165 & 1,815 & 4,315 & 6,450 & 4,785 \\
\hline 2017 & 765 & 2,110 & 5,980 & 3,220 & 6,455 & 1,720 & 3,750 & 5,390 & 4,225 \\
\hline 2018 & 730 & 1,985 & 5,800 & 3,095 & 6,280 & 1,635 & 3,620 & 5,345 & 4,115 \\
\hline 2019 & 680 & 1,915 & 5,640 & 3,055 & 6,145 & 1,585 & 3,450 & 5,265 & 4,010 \\
\hline 2020 & 695 & 1,975 & 5,765 & 3,210 & 6,550 & 1,545 & 3,495 & 5,330 & 4,140 \\
\hline
\end{tabular}

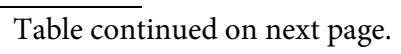


Appendix Table 4. Average Reported Value of Nebraska Farmland for Different Types of Land by Agricultural Statistics District, 1978-2020 ${ }^{a}$ (continued)

\begin{tabular}{|c|c|c|c|c|c|c|c|c|c|}
\hline \multirow{2}{*}{ Year } & \multicolumn{10}{|c|}{ Agricultural Statistics District } \\
\cline { 2 - 9 } & Northwest & North & Northeast & Central & East & Southwest & South & Southeast & State ${ }^{\text {b }}$ \\
\hline
\end{tabular}

- . . . . . . . . . - Dollars per Acre- . . . . . . . . . -

Grazing Land (Tillable)

\begin{tabular}{|c|c|c|c|c|c|c|c|c|c|}
\hline 1978 & 177 & 191 & 433 & 299 & 549 & 215 & 465 & 433 & 244 \\
\hline 1979 & 186 & 229 & 521 & 347 & 701 & 259 & 479 & 574 & 285 \\
\hline 1980 & 200 & 261 & 583 & 395 & 760 & 307 & 621 & 643 & 324 \\
\hline 1981 & 251 & 257 & 622 & 435 & 881 & 332 & 697 & 636 & 353 \\
\hline 1982 & 248 & 248 & 605 & 422 & 824 & 317 & 710 & 654 & 344 \\
\hline 1983 & 198 & 234 & 571 & 405 & 739 & 315 & 555 & 589 & 311 \\
\hline 1984 & 187 & 233 & 500 & 325 & 661 & 285 & 519 & 521 & 285 \\
\hline 1985 & 146 & 180 & 392 & 259 & 510 & 205 & 339 & 357 & 215 \\
\hline 1986 & 101 & 135 & 275 & 166 & 366 & 146 & 250 & 241 & 152 \\
\hline 1987 & 77 & 99 & 267 & 135 & 336 & 115 & 187 & 236 & 123 \\
\hline 1988 & 80 & 107 & 294 & 168 & 361 & 100 & 208 & 292 & 132 \\
\hline 1989 & 104 & 150 & 362 & 217 & 418 & 130 & 253 & 341 & 170 \\
\hline 1990 & 102 & 185 & 381 & 270 & 459 & 153 & 296 & 360 & 194 \\
\hline 1991 & 107 & 200 & 394 & 308 & 495 & 168 & 338 & 366 & 209 \\
\hline 1992 & 113 & 213 & 395 & 339 & 500 & 169 & 348 & 395 & 220 \\
\hline 1993 & 121 & 195 & 427 & 359 & 524 & 171 & 371 & 418 & 223 \\
\hline 1994 & 128 & 215 & 440 & 380 & 573 & 192 & 407 & 460 & 242 \\
\hline 1995 & 128 & 223 & 456 & 400 & 611 & 193 & 414 & 471 & 249 \\
\hline 1996 & 125 & 225 & 473 & 406 & 617 & 196 & 413 & 483 & 251 \\
\hline 1997 & 135 & 250 & 512 & 440 & 686 & 200 & 433 & 519 & 272 \\
\hline 1998 & 153 & 265 & 550 & 461 & 741 & 227 & 467 & 575 & 295 \\
\hline 1999 & 165 & 270 & 569 & 456 & 735 & 234 & 470 & 575 & 301 \\
\hline 2000 & 173 & 275 & 581 & 471 & 731 & 256 & 464 & 588 & 310 \\
\hline 2001 & 171 & 288 & 670 & 505 & 750 & 291 & 524 & 578 & 329 \\
\hline 2002 & 182 & 299 & 706 & 523 & 796 & 325 & 537 & 629 & 348 \\
\hline 2003 & 180 & 280 & 750 & 562 & 801 & 290 & 534 & 640 & 342 \\
\hline 2004 & 212 & 307 & 794 & 611 & 926 & 305 & 558 & 716 & 377 \\
\hline 2005 & 225 & 330 & 919 & 658 & 1,075 & 316 & 640 & 830 & 412 \\
\hline 2006 & 251 & 383 & 1,067 & 740 & 1,224 & 349 & 651 & 962 & 466 \\
\hline 2007 & 282 & 475 & 1,343 & 848 & 1,493 & 387 & 684 & 1,083 & 574 \\
\hline 2008 & 316 & 567 & 1,578 & 1,018 & 1,927 & 417 & 887 & 1,380 & 651 \\
\hline 2009 & 330 & 565 & 1,525 & 996 & 1,876 & 416 & 936 & 1,358 & 649 \\
\hline
\end{tabular}

Table continued on next page. 
Appendix Table 4. Average Reported Value of Nebraska Farmland for Different Types of Land by Agricultural Statistics District, 1978-2020 ${ }^{\text {a }}$ (continued)

\begin{tabular}{|c|c|c|c|c|c|c|c|c|c|}
\hline \multirow{2}{*}{ Year } & \multicolumn{8}{|c|}{ Agricultural Statistics District } \\
\cline { 2 - 8 } & Northwest & North & Northeast & Central & East & Southwest & South & Southeast & State ${ }^{\mathrm{b}}$ \\
\hline
\end{tabular}

Grazing Land (Tillable)

$\begin{array}{lrrrrrrrrr}\mathbf{2 0 1 0} & 320 & 595 & 1,640 & 990 & 1,965 & 435 & 960 & 1,430 & 669 \\ \mathbf{2 0 1 1} & 340 & 740 & 2,090 & 1,145 & 2,365 & 490 & 1,100 & 1,795 & 797 \\ \mathbf{2 0 1 2} & 410 & 880 & 2,690 & 1,670 & 2,965 & 590 & 1,500 & 2,400 & 1,010 \\ \mathbf{2 0 1 3} & 425 & 1,050 & 3,575 & 2,075 & 3,390 & 665 & 2,075 & 3,195 & 1,230 \\ \mathbf{2 0 1 4} & 550 & 1,150 & 4,075 & 2,300 & 3,620 & 890 & 2,430 & 3,285 & 1,390 \\ \mathbf{2 0 1 5} & 535 & 1,395 & 3,695 & 2,615 & 4,205 & 1,135 & 2,350 & 3,035 & 1,515 \\ \mathbf{2 0 1 6} & 565 & 1,325 & 3,955 & 2,460 & 4,370 & 1,070 & 2,240 & 3,200 & 1,495 \\ \mathbf{2 0 1 7} & 530 & 1,170 & 3,665 & 2,155 & 3,765 & 975 & 2,040 & 2,780 & 1,335 \\ \mathbf{2 0 1 8} & 510 & 1,075 & 3,330 & 1,935 & 3,335 & 950 & 1,950 & 2,845 & 1,250 \\ \mathbf{2 0 2 0} & 500 & 1,040 & 3,125 & 1,750 & 3,075 & 880 & 1,875 & 2,760 & 1,185 \\ & & & & & & & & & \\ \mathbf{2 0 2 0} & 520 & 1,105 & 3,220 & 1,875 & 3,190 & 925 & 1,835 & 2,920 & 1,240\end{array}$

Table continued on next page. 
Appendix Table 4. Average Reported Value of Nebraska Farmland for Different Types of Land by Agricultural Statistics District, $1978-2020^{a}$ (continued)

\begin{tabular}{|c|c|c|c|c|c|c|c|c|c|}
\hline \multirow{2}{*}{ Year } & \multicolumn{8}{|c|}{ Agricultural Statistics District } \\
\cline { 2 - 9 } & Northwest & North & Northeast & Central & East & Southwest & South & Southeast & State ${ }^{\mathrm{b}}$ \\
\hline
\end{tabular}

- . . . . . . . . - Dollars per Acre- . . . . . . . . -

\section{Grazing Land (Nontillable)}

\begin{tabular}{|c|c|c|c|c|c|c|c|c|c|}
\hline 1978 & 115 & 126 & 308 & 216 & 384 & 119 & 268 & 315 & 153 \\
\hline 1979 & 134 & 156 & 340 & 267 & 486 & 148 & 309 & 417 & 186 \\
\hline 1980 & 143 & 169 & 394 & 304 & 549 & 190 & 346 & 473 & 207 \\
\hline 1981 & 164 & 182 & 418 & 339 & 620 & 217 & 398 & 474 & 228 \\
\hline 1982 & 168 & 183 & 412 & 329 & 584 & 195 & 418 & 472 & 225 \\
\hline 1983 & 151 & 169 & 375 & 283 & 511 & 181 & 339 & 460 & 204 \\
\hline 1984 & 134 & 152 & 350 & 248 & 455 & 168 & 328 & 384 & 183 \\
\hline 1985 & 94 & 115 & 258 & 192 & 341 & 118 & 236 & 243 & 134 \\
\hline 1986 & 71 & 85 & 179 & 131 & 262 & 84 & 158 & 178 & 97 \\
\hline 1987 & 60 & 71 & 166 & 106 & 238 & 68 & 120 & 173 & 82 \\
\hline 1988 & 58 & 76 & 189 & 128 & 270 & 75 & 152 & 220 & 90 \\
\hline 1989 & 71 & 109 & 242 & 183 & 310 & 101 & 209 & 266 & 122 \\
\hline 1990 & 83 & 134 & 272 & 225 & 340 & 113 & 233 & 298 & 144 \\
\hline 1991 & 86 & 148 & 284 & 252 & 357 & 125 & 254 & 314 & 157 \\
\hline 1992 & 90 & 155 & 302 & 267 & 373 & 126 & 261 & 316 & 163 \\
\hline 1993 & 93 & 157 & 322 & 278 & 382 & 136 & 290 & 330 & 169 \\
\hline 1994 & 98 & 167 & 325 & 302 & 388 & 153 & 307 & 354 & 181 \\
\hline 1995 & 106 & 175 & 337 & 308 & 421 & 163 & 308 & 357 & 189 \\
\hline 1996 & 103 & 173 & 347 & 299 & 428 & 155 & 296 & 367 & 186 \\
\hline 1997 & 115 & 183 & 366 & 327 & 468 & 163 & 318 & 412 & 200 \\
\hline 1998 & 128 & 199 & 395 & 366 & 516 & 189 & 337 & 473 & 221 \\
\hline 1999 & 127 & 192 & 411 & 350 & 507 & 187 & 327 & 476 & 216 \\
\hline 2000 & 137 & 206 & 432 & 365 & 510 & 193 & 333 & 478 & 228 \\
\hline 2001 & 142 & 220 & 475 & 386 & 532 & 200 & 353 & 479 & 240 \\
\hline 2002 & 151 & 218 & 515 & 419 & 584 & 213 & 378 & 499 & 250 \\
\hline 2003 & 149 & 210 & 559 & 446 & 590 & 219 & 389 & 490 & 250 \\
\hline 2004 & 163 & 230 & 619 & 494 & 655 & 240 & 422 & 550 & 275 \\
\hline 2005 & 191 & 269 & 706 & 543 & 784 & 273 & 482 & 629 & 317 \\
\hline 2006 & 215 & 307 & 800 & 588 & 907 & 298 & 497 & 688 & 353 \\
\hline 2007 & 250 & 358 & 900 & 668 & 1,033 & 310 & 553 & 749 & 402 \\
\hline 2008 & 287 & 386 & 975 & 781 & 1,219 & 344 & 658 & 883 & 451 \\
\hline 2009 & 281 & 378 & 1,000 & 733 & 1,202 & 370 & 707 & 945 & 449 \\
\hline
\end{tabular}

\footnotetext{
Table continued on next page.
} 
Appendix Table 4. Average Reported Value of Nebraska Farmland for Different Types of Land by Agricultural Statistics District, $1978-2020^{a}$ (continued)

\begin{tabular}{|c|c|c|c|c|c|c|c|c|c|}
\hline \multirow{2}{*}{ Year } & \multicolumn{8}{c|}{ Agricultural Statistics District } \\
\cline { 2 - 8 } & Northwest & North & Northeast & Central & East & Southwest & South & Southeast & State ${ }^{\text {b }}$ \\
\hline
\end{tabular}

\section{Grazing Land (Nontillable)}

\begin{tabular}{|c|c|c|c|c|c|c|c|c|c|}
\hline 2010 & 260 & 340 & 1,060 & 685 & 1,265 & 350 & 710 & 975 & 425 \\
\hline 2011 & 280 & 390 & 1,210 & 810 & 1,530 & 415 & 805 & 1,195 & 490 \\
\hline 2012 & 330 & 450 & 1,460 & 1,005 & 1,975 & 475 & 1,060 & 1,485 & 585 \\
\hline 2013 & 370 & 500 & 1,850 & 1,300 & 2,225 & 570 & 1,375 & 1,875 & 695 \\
\hline 2014 & 405 & 625 & 2,490 & 1,670 & 2,500 & 805 & 1,775 & 2,170 & 865 \\
\hline 2015 & 490 & 745 & 2,580 & 2,030 & 3,010 & 945 & 1,815 & 2,275 & 1,005 \\
\hline 2016 & 480 & 740 & 2,475 & 1,925 & 2,795 & 915 & 1,690 & 2,205 & 975 \\
\hline 2017 & 465 & 705 & 2,230 & 1,685 & 2,495 & 820 & 1,500 & 2,005 & 895 \\
\hline 2018 & 435 & 640 & 2,135 & 1,545 & 2,345 & 785 & 1,460 & 2,045 & 835 \\
\hline 2019 & 410 & 625 & 1,995 & 1,405 & 2,255 & 735 & 1,335 & 1,970 & 795 \\
\hline 2020 & 430 & 660 & 2,045 & 1,460 & 2,405 & 750 & 1,380 & 2,055 & 830 \\
\hline
\end{tabular}

Table continued on next page. 
Appendix Table 4. Average Reported Value of Nebraska Farmland for Different Types of Land by Agricultural Statistics District, $1978-2020^{a}$ (continued)

\begin{tabular}{|c|c|c|c|c|c|c|c|c|c|}
\hline \multirow{2}{*}{ Year } & \multicolumn{9}{|c|}{ Agricultural Statistics District } \\
\cline { 2 - 9 } & Northwest & North & Northeast & Central & East & Southwest & South & Southeast & State ${ }^{\mathrm{b}}$ \\
\hline
\end{tabular}

- . . . . . . . . - Dollars per Acre- . . . . . . . . .

Hayland

\begin{tabular}{|c|c|c|c|c|c|c|c|c|c|}
\hline 1978 & 232 & 266 & 370 & 372 & 477 & 231 & 298 & 371 & 306 \\
\hline 1979 & 287 & 308 & 436 & 397 & 593 & 281 & 545 & 509 & 367 \\
\hline 1980 & 301 & 338 & 506 & 441 & 699 & 349 & 402 & 554 & 405 \\
\hline 1981 & 323 & 331 & 558 & 482 & 738 & 368 & 417 & 532 & 419 \\
\hline 1982 & 328 & 334 & 544 & 472 & 714 & 344 & 445 & 557 & 417 \\
\hline 1983 & 290 & 286 & 509 & 408 & 658 & 344 & 375 & 496 & 371 \\
\hline 1984 & 283 & 247 & 497 & 295 & 568 & 329 & 369 & 463 & 329 \\
\hline 1985 & 261 & 206 & 332 & 273 & 470 & 250 & 258 & 311 & 265 \\
\hline 1986 & 190 & 154 & 233 & 230 & 335 & 182 & 190 & 219 & 196 \\
\hline 1987 & 160 & 119 & 188 & 195 & 271 & 148 & 175 & 201 & 160 \\
\hline 1988 & 144 & 130 & 238 & 230 & 317 & 178 & 202 & 245 & 181 \\
\hline 1989 & 194 & 183 & 295 & 275 & 382 & 220 & 268 & 291 & 233 \\
\hline 1990 & 217 & 218 & 326 & 328 & 405 & 245 & 278 & 328 & 266 \\
\hline 1991 & 225 & 240 & 330 & 350 & 434 & 252 & 286 & 361 & 284 \\
\hline 1992 & 248 & 247 & 325 & 365 & 452 & 250 & 329 & 341 & 293 \\
\hline 1993 & 242 & 265 & 365 & 366 & 473 & 251 & 360 & 358 & 308 \\
\hline 1994 & 251 & 296 & 392 & 400 & 511 & 278 & 386 & 370 & 335 \\
\hline 1995 & 260 & 300 & 418 & 408 & 528 & 277 & 397 & 385 & 344 \\
\hline 1996 & 270 & 300 & 429 & 403 & 524 & 289 & 396 & 402 & 347 \\
\hline 1997 & 295 & 325 & 459 & 438 & 575 & 300 & 403 & 435 & 375 \\
\hline 1998 & 315 & 345 & 517 & 472 & 640 & 336 & 437 & 497 & 408 \\
\hline 1999 & 318 & 325 & 507 & 457 & 625 & 330 & 412 & 502 & 395 \\
\hline 2000 & 313 & 358 & 539 & 444 & 618 & 350 & 398 & 463 & 409 \\
\hline 2001 & 306 & 381 & 563 & 458 & 677 & 364 & 450 & 502 & 430 \\
\hline 2002 & 313 & 388 & 611 & 502 & 694 & 373 & 483 & 529 & 449 \\
\hline 2003 & 319 & 380 & 660 & 557 & 765 & 375 & 508 & 575 & 468 \\
\hline 2004 & 339 & 433 & 715 & 577 & 815 & 413 & 513 & 611 & 509 \\
\hline 2005 & 383 & 438 & 780 & 600 & 928 & 416 & 600 & 669 & 541 \\
\hline 2006 & 430 & 481 & 871 & 679 & 1,071 & 449 & 633 & 760 & 604 \\
\hline 2007 & 500 & 568 & 1,005 & 791 & 1,255 & 530 & 717 & 875 & 705 \\
\hline 2008 & 570 & 688 & 1,220 & 998 & 1,525 & 660 & 859 & 1,006 & 853 \\
\hline 2009 & 550 & 660 & 1,250 & 904 & 1,440 & 700 & 870 & 991 & 827 \\
\hline
\end{tabular}

Table continued on next page. 
Appendix Table 4. Average Reported Value of Nebraska Farmland for Different Types of Land by Agricultural Statistics District, 1978-2020 ${ }^{a}$ (continued)

\begin{tabular}{|c|c|c|c|c|c|c|c|c|c|}
\hline \multirow{2}{*}{ Year } & \multicolumn{9}{|c|}{ Agricultural Statistics District } \\
\hline & Northwest & North & Northeast & Central & East & Southwest & South & Southeast & State $^{b}$ \\
\hline
\end{tabular}

\section{Hayland}

$\begin{array}{lrrrrrrrrr}\mathbf{2 0 1 0} & 525 & 625 & 1,275 & 880 & 1,465 & 660 & 880 & 1,015 \\ \mathbf{2 0 1 1} & 550 & 785 & 1,485 & 1,100 & 1,840 & 700 & 1,085 & 1,250 & 810 \\ \mathbf{2 0 1 2} & 620 & 950 & 1,985 & 1,425 & 2,500 & 925 & 1,450 & 1,665 \\ \mathbf{2 0 1 3} & 780 & 1,150 & 2,625 & 1,850 & 3,325 & 1,160 & 1,800 & 2,065 \\ \mathbf{2 0 1 4} & 1,025 & 1,660 & 2,915 & 2,350 & 3,280 & 1,545 & 2,350 & 2,515 \\ \mathbf{2 0 1 5} & 1,115 & 1,905 & 3,630 & 2,890 & 4,080 & 1,965 & 2,955 & 3,100 & 1,245 \\ \mathbf{2 0 1 6} & 890 & 1,460 & 3,430 & 2,585 & 3,200 & 1,700 & 2,340 & 2,780 \\ \mathbf{2 0 1 7} & 795 & 1,370 & 3,295 & 2,170 & 3,090 & 1,485 & 2,160 & 2,680 \\ \mathbf{2 0 1 8} & 765 & 1,265 & 3,155 & 1,980 & 2,990 & 1,365 & 2,060 & 2,615 \\ \mathbf{2 0 1 9} & 710 & 1,140 & 3,020 & 1,885 & 3,040 & 1,255 & 1,990 & 2,645 & 1,815 \\ & & & & & & & & 1,710 \\ \mathbf{2 0 2 0} & 715 & 1,170 & 3,065 & 1,925 & 2,965 & 1,290 & 1,905 & 2,730\end{array}$

Table continued on next page. 
Appendix Table 4. Average Reported Value of Nebraska Farmland for Different Types of Land by Agricultural Statistics District, $1978-2020^{a}$ (continued)

\begin{tabular}{|c|c|c|c|c|c|c|c|c|c|}
\hline \multirow{2}{*}{ Year } & \multicolumn{7}{|c|}{ Agricultural Statistics District } \\
\cline { 2 - 9 } & Northwest & North & Northeast & Central & East & Southwest & South & Southeast & State ${ }^{\text {b }}$ \\
\hline
\end{tabular}

- . . . . . . . . - Dollars per Acre- . . . . . . . . -

\section{Gravity Irrigated Cropland}

\begin{tabular}{|c|c|c|c|c|c|c|c|c|c|}
\hline 1978 & 1,246 & 796 & 1,030 & 1,545 & 1,624 & 1,134 & 1,412 & 1,404 & 1,435 \\
\hline 1979 & 1,300 & 964 & 1,289 & 1,705 & 1,910 & 1,197 & 1,746 & 1,772 & 1,668 \\
\hline 1980 & 1,369 & 1,020 & 1,547 & 1,976 & 2,317 & 1,329 & 2,046 & 2,026 & 1,940 \\
\hline 1981 & 1,555 & 1,054 & 1,781 & 2,088 & 2,403 & 1,493 & 2,230 & 2,026 & 2,063 \\
\hline 1982 & 1,580 & 1,033 & 1,771 & 2,053 & 2,269 & 1,598 & 2,254 & 1,924 & 2,023 \\
\hline 1983 & 1,361 & 1,000 & 1,430 & 1,798 & 1,969 & 1,412 & 1,872 & 1,854 & 1,763 \\
\hline 1984 & 1,269 & 1,020 & 1,429 & 1,613 & 1,838 & 1,250 & 1,762 & 1,639 & 1,623 \\
\hline 1985 & 1,042 & 817 & 1,102 & 1,304 & 1,329 & 1,010 & 1,283 & 1,171 & 1,229 \\
\hline 1986 & 754 & 612 & 900 & 940 & 975 & 867 & 963 & 957 & 925 \\
\hline 1987 & 650 & 567 & 775 & 802 & 959 & 718 & 863 & 843 & 831 \\
\hline 1988 & 668 & 691 & 862 & 948 & 1,151 & 740 & 994 & 956 & 956 \\
\hline 1989 & 815 & 900 & 1,100 & 1,210 & 1,462 & 841 & 1,232 & 1,170 & 1,194 \\
\hline 1990 & 841 & 900 & 1,186 & 1,413 & 1,513 & 895 & 1,390 & 1285 & 1,304 \\
\hline 1991 & 834 & 917 & 1,250 & 1,518 & 1,622 & 975 & 1,480 & 1,306 & 1,381 \\
\hline 1992 & 889 & 1,035 & 1,221 & 1,563 & 1,653 & 1,021 & 1,583 & 1,413 & 1,439 \\
\hline 1993 & 857 & 1,058 & 1,246 & 1,609 & 1,730 & 1,018 & 1,643 & 1,479 & 1,484 \\
\hline 1994 & 875 & 1,070 & 1,250 & 1,666 & 1,842 & 1,093 & 1,728 & 1,568 & 1,558 \\
\hline 1995 & 857 & 1,065 & 1,260 & 1,671 & 1,887 & 1,090 & 1,731 & 1,606 & 1,573 \\
\hline 1996 & 870 & 1,070 & 1,361 & 1,738 & 1,989 & 1,138 & 1,800 & 1,697 & 1,646 \\
\hline 1997 & 890 & 1,115 & 1,466 & 1,858 & 2,160 & 1,167 & 1,943 & 1,853 & 1,768 \\
\hline 1998 & 925 & 1,150 & 1,575 & 1,972 & 2,340 & 1,200 & 2,042 & 1,936 & 1,876 \\
\hline 1999 & 894 & 1,050 & 1,575 & 1,861 & 2,247 & 1,198 & 1,945 & 1,813 & 1,792 \\
\hline 2000 & 907 & 1,025 & 1,696 & 1,754 & 2,279 & 1,325 & 1,856 & 1,831 & 1,777 \\
\hline 2001 & 900 & 1,033 & 1,715 & 1,729 & 2,273 & 1,279 & 1,810 & 1,843 & 1,760 \\
\hline 2002 & 914 & 1,080 & 1,759 & 1,825 & 2,298 & 1,350 & 1,827 & 1,928 & 1,809 \\
\hline 2003 & 890 & 1,075 & 1,760 & 1,835 & 2,401 & 1,213 & 1,863 & 1,899 & 1,828 \\
\hline 2004 & 925 & 1,125 & 1,867 & 1,961 & 2,531 & 1,297 & 1,969 & 2,087 & 1,944 \\
\hline 2005 & 975 & 1,183 & 1,980 & 2,153 & 2,691 & 1,365 & 2,021 & 2,173 & 2,061 \\
\hline 2006 & 1,036 & 1,199 & 2,310 & 2,295 & 2,953 & 1,340 & 1,925 & 2,400 & 2,186 \\
\hline 2007 & 1,195 & 1,305 & 2,795 & 2,431 & 3,323 & 1,275 & 2,199 & 2,719 & 2,430 \\
\hline 2008 & 1,475 & 1,633 & 3,550 & 2,934 & 4,080 & 1,550 & 2,689 & 3,477 & 2,992 \\
\hline 2009 & 1,495 & 1,715 & 3,580 & 3,030 & 4,096 & 1,690 & 3,075 & 3,545 & 3,109 \\
\hline
\end{tabular}

Table continued on next page. 
Appendix Table 4. Average Reported Value of Nebraska Farmland for Different Types of Land by Agricultural Statistics District, 1978-2020 ${ }^{a}$ (continued)

\begin{tabular}{|c|c|c|c|c|c|c|c|c|c|}
\hline \multirow{2}{*}{ Year } & \multicolumn{8}{c|}{ Agricultural Statistics District } \\
\cline { 2 - 8 } & Northwest & North & Northeast & Central & East & Southwest & South & Southeast & State ${ }^{\text {b }}$ \\
\hline
\end{tabular}

Gravity Irrigated Cropland

$\begin{array}{llllllllll}\mathbf{2 0 1 0} & 1,625 & 1,800 & 3,715 & 3,155 & 4,510 & 1,785 & 3,095 & 3,560 & 3,271 \\ \mathbf{2 0 1 1} & 1,980 & 2,050 & 4,500 & 3,940 & 5,725 & 1,975 & 3,940 & 4,300 & 4,071 \\ \mathbf{2 0 1 2} & 2,440 & 2,625 & 6,250 & 5,215 & 7,420 & 2,865 & 5,170 & 5,800 & 5,365 \\ \mathbf{2 0 1 3} & 2,875 & 3,100 & 7,850 & 6,900 & 8,750 & 3,850 & 7,060 & 7,715 & 6,835 \\ \mathbf{2 0 1 4} & 3,040 & 4,215 & 7,455 & 8,065 & 8,750 & 4,515 & 7,290 & 8,330 & 7,310 \\ \mathbf{2 0 1 5} & 3,235 & 4,135 & 7,355 & 6,905 & 8,445 & 4,435 & 7,095 & 7,995 & 6,900 \\ \mathbf{2 0 1 6} & 2,970 & 3,970 & 7,220 & 6,560 & 8,115 & 4,390 & 6,265 & 7,375 & 6,480 \\ \mathbf{2 0 1 7} & 2,580 & 3,835 & 6,890 & 6,195 & 7,640 & 4,155 & 6,020 & 6,615 & 6,070 \\ \mathbf{2 0 1 8} & 2,340 & 3,645 & 6,680 & 5,775 & 7,455 & 3,910 & 5,795 & 6,295 & 5,795 \\ \mathbf{2 0 1 9} & 2,245 & 3,570 & 6,510 & 5,860 & 7,585 & 3,700 & 5,365 & 5,900 & 5,690 \\ \mathbf{2 0 2 0} & 2,135 & 3,645 & 6,700 & 5,805 & 7,725 & 3,570 & 5,450 & 6,235 & 5,755\end{array}$

Table continued on next page. 
Appendix Table 4. Average Reported Value of Nebraska Farmland for Different Types of Land by Agricultural Statistics District, $1978-2020^{a}$ (continued)

\begin{tabular}{|c|c|c|c|c|c|c|c|c|c|}
\hline \multirow{2}{*}{ Year } & \multicolumn{7}{|c|}{ Agricultural Statistics District } \\
\cline { 2 - 9 } & Northwest & North & Northeast & Central & East & Southwest & South & Southeast & State ${ }^{\text {b }}$ \\
\hline
\end{tabular}

- . . . . . . . . - Dollars per Acre- . . . . . . . . -

Center Pivot Irrigated Cropland ${ }^{c}$

\begin{tabular}{|c|c|c|c|c|c|c|c|c|c|}
\hline 1978 & 771 & 678 & 956 & 877 & 1,484 & 813 & 1,023 & 1,286 & 1,015 \\
\hline 1979 & 915 & 770 & 1164 & 1,076 & 1,690 & 895 & 1,291 & 1,590 & 1,201 \\
\hline 1980 & 894 & 886 & 1,372 & 1,223 & 2,043 & 971 & 1,535 & 1,795 & 1,384 \\
\hline 1981 & 973 & 816 & 1,456 & 1,312 & 2,110 & 1,105 & 1,732 & 1,900 & 1,470 \\
\hline 1982 & 989 & 810 & 1,332 & 1,270 & 2,010 & 1,123 & 1,681 & 1,748 & 1,410 \\
\hline 1983 & 847 & 769 & 1,217 & 1,016 & 1,727 & 926 & 1,391 & 1,643 & 1,222 \\
\hline 1984 & 809 & 698 & 1,130 & 969 & 1,655 & 827 & 1,350 & 1,465 & 1,143 \\
\hline 1985 & 691 & 581 & 875 & 850 & 1,243 & 691 & 1,055 & 1,020 & 899 \\
\hline 1986 & 496 & 400 & 700 & 628 & 970 & 558 & 788 & 788 & 689 \\
\hline 1987 & 417 & 396 & 703 & 541 & 888 & 487 & 665 & 723 & 626 \\
\hline 1988 & 446 & 441 & 800 & 622 & 1,038 & 548 & 792 & 820 & 718 \\
\hline 1989 & 532 & 604 & 993 & 779 & 1,320 & 683 & 1,021 & 1,056 & 910 \\
\hline 1990 & 619 & 710 & 1,090 & 910 & 1,393 & 765 & 1,117 & 1,133 & 1,003 \\
\hline 1991 & 651 & 714 & 1,129 & 1,053 & 1,461 & 748 & 1,229 & 1,194 & 1,060 \\
\hline 1992 & 681 & 740 & 1,084 & 1,085 & 1,510 & 783 & 1,263 & 1,228 & 1,083 \\
\hline 1993 & 641 & 745 & 1,156 & 1,160 & 1,593 & 799 & 1,356 & 1,346 & 1,140 \\
\hline 1994 & 690 & 800 & 1,215 & 1,200 & 1,707 & 850 & 1,425 & 1,413 & 1,206 \\
\hline 1995 & 693 & 825 & 1,254 & 1,268 & 1,793 & 882 & 1,454 & 1,474 & 1,254 \\
\hline 1996 & 710 & 913 & 1,320 & 1,340 & 1,930 & 981 & 1,550 & 1,565 & 1,342 \\
\hline 1997 & 748 & 962 & 1,427 & 1,507 & 2,111 & 1,058 & 1,696 & 1,725 & 1,465 \\
\hline 1998 & 829 & 1,020 & 1,583 & 1,698 & 2,332 & 1,139 & 1,863 & 1,907 & 1,614 \\
\hline 1999 & 750 & 984 & 1,581 & 1,616 & 2,288 & 1,124 & 1,830 & 1,806 & 1,569 \\
\hline 2000 & 750 & 981 & 1,609 & 1,579 & 2,424 & 1,192 & 1,795 & 1,810 & 1,600 \\
\hline 2001 & 742 & 965 & 1,653 & 1,602 & 2,420 & 1,152 & 1,778 & 1,898 & 1,608 \\
\hline 2002 & 775 & 1,043 & 1,775 & 1,693 & 2,401 & 1,167 & 1,830 & 1,959 & 1,660 \\
\hline 2003 & 750 & 1,075 & 1,840 & 1,785 & 2,460 & 1,033 & 1,846 & 1,981 & 1,679 \\
\hline 2004 & 806 & 1,211 & 2,004 & 1,901 & 2,669 & 1,123 & 2,044 & 2,218 & 1,833 \\
\hline 2005 & 924 & 1,342 & 2,234 & 2,140 & 3,042 & 1,279 & 2,145 & 2,414 & 2,045 \\
\hline 2006 & 967 & 1,480 & 2,600 & 2,224 & 3,253 & 1,344 & 2,010 & 2,743 & 2,197 \\
\hline 2007 & 1,112 & 1,733 & 3,077 & 2,521 & 3,646 & 1,575 & 2,254 & 3,055 & 2,509 \\
\hline 2008 & 1,400 & 2,221 & 3,871 & 3,082 & 4,464 & 2,071 & 3,034 & 3,818 & 3,157 \\
\hline 2009 & 1,535 & 2,378 & 3,912 & 3,277 & 4,422 & 2,391 & 3,474 & 3,850 & 3,304 \\
\hline
\end{tabular}

Table continued on next page. 
Appendix Table 4. Average Reported Value of Nebraska Farmland for Different Types of Land by Agricultural Statistics District, $1978-2020^{a}$ (continued)

\begin{tabular}{|c|c|c|c|c|c|c|c|c|c|}
\hline \multirow{2}{*}{ Year } & \multicolumn{9}{|c|}{ Agricultural Statistics District } \\
\hline & Northwest & North & Northeast & Central & East & Southwest & South & Southeast & State $^{b}$ \\
\hline
\end{tabular}

Center Pivot Irrigated Cropland ${ }^{c}$

$\begin{array}{lrrrrrrrrr}\mathbf{2 0 1 0} & 1,650 & 2,485 & 4,140 & 3,470 & 4,890 & 2,475 & 3,575 & 4,125 & 3,520 \\ \mathbf{2 0 1 1} & 1,975 & 2,955 & 5,100 & 4,530 & 6,175 & 2,760 & 4,470 & 5,020 & 4,343 \\ \mathbf{2 0 1 2} & 2,535 & 3,970 & 7,100 & 6,190 & 7,950 & 3,830 & 5,925 & 6,820 & 5,835 \\ \mathbf{2 0 1 3} & 3,115 & 5,225 & 8,715 & 8,120 & 10,025 & 5,200 & 8,350 & 9,400 & 7,590 \\ \mathbf{2 0 1 4} & 3,700 & 4,985 & 8,855 & 8,940 & 9,860 & 5,750 & 8,440 & 9,760 & 7,685 \\ \mathbf{2 0 1 5} & 3,625 & 4,835 & 8,150 & 7,825 & 9,575 & 5,790 & 8,270 & 9,425 & 7,315 \\ \mathbf{2 0 1 6} & 3,290 & 4,350 & 7,880 & 7,530 & 9,410 & 5,330 & 7,240 & 9,185 & 6,940 \\ \mathbf{2 0 1 7} & 2,815 & 4,150 & 7,445 & 6,885 & 8,700 & 4,510 & 6,700 & 7,820 & 6,295 \\ \mathbf{2 0 1 8} & 2,700 & 4,020 & 7,310 & 6,510 & 8,645 & 4,265 & 6,520 & 7,720 & 6,130 \\ \mathbf{2 0 1 9} & 2,565 & 3,905 & 7,210 & 6,390 & 8,485 & 4,110 & 6,150 & 7,470 & 5,970 \\ \mathbf{2 0 2 0} & 2,460 & 3,950 & 7,390 & 6,675 & 8,900 & 3,990 & 6,465 & 7,680\end{array}$

Table continued on next page. 
Appendix Table 4. Average Reported Value of Nebraska Farmland for Different Types of Land by Agricultural Statistics District, $1978-2020^{a}$ (continued)

\begin{tabular}{|c|c|c|c|c|c|c|c|c|c|}
\hline \multirow{2}{*}{ Year } & \multicolumn{7}{|c|}{ Agricultural Statistics District } \\
\cline { 2 - 9 } & Northwest & North & Northeast & Central & East & Southwest & South & Southeast & State \\
\hline
\end{tabular}

- . . . . . . . . - Dollars per Acre- . . . . . . . . .

All-Land Average ${ }^{\mathrm{d}}$

\begin{tabular}{|c|c|c|c|c|c|c|c|c|c|}
\hline 1978 & 261 & 205 & 686 & 571 & 1,116 & 659 & 747 & 810 & 489 \\
\hline 1979 & 290 & 248 & 846 & 669 & 1,348 & 402 & 914 & 1,005 & 584 \\
\hline 1980 & 310 & 274 & 998 & 764 & 1,634 & 465 & 1,069 & 1,165 & 677 \\
\hline 1981 & 366 & 275 & 1,078 & 826 & 1,709 & 531 & 1,206 & 1,219 & 729 \\
\hline 1982 & 365 & 273 & 998 & 803 & 1,611 & 518 & 1,199 & 1,138 & 701 \\
\hline 1983 & 319 & 251 & 898 & 687 & 1,411 & 46 & 997 & 1,068 & 621 \\
\hline 1984 & 299 & 232 & 833 & 617 & 1,319 & 426 & 954 & 957 & 574 \\
\hline 1985 & 244 & 182 & 661 & 511 & 996 & 338 & 765 & 669 & 446 \\
\hline 1986 & 181 & 137 & 518 & 371 & 746 & 266 & 538 & 498 & 335 \\
\hline 1987 & 157 & 116 & 505 & 318 & 700 & 231 & 466 & 167 & 305 \\
\hline 1988 & 165 & 126 & 572 & 375 & 805 & 243 & 539 & 558 & 342 \\
\hline 1989 & 199 & 173 & 697 & 478 & 998 & 306 & 675 & 688 & 428 \\
\hline 1990 & 209 & 206 & 756 & 561 & 1,059 & 340 & 735 & 738 & 470 \\
\hline 1991 & 217 & 216 & 762 & 627 & 1,103 & 341 & 792 & 743 & 490 \\
\hline 1992 & 230 & 229 & 748 & 648 & 1,145 & 350 & 825 & 777 & 506 \\
\hline 1993 & 229 & 229 & 804 & 683 & 1,206 & 351 & 884 & 825 & 528 \\
\hline 1994 & 239 & 248 & 852 & 716 & 1,310 & 378 & 936 & 872 & 563 \\
\hline 1995 & 240 & 256 & 879 & 739 & 1,368 & 389 & 949 & 903 & 581 \\
\hline 1996 & 245 & 262 & 915 & 765 & 1,470 & 409 & 990 & 952 & 608 \\
\hline 1997 & 261 & 281 & 985 & 839 & 1,595 & 432 & 1,071 & 1,033 & 657 \\
\hline 1998 & 279 & 301 & 1,083 & 916 & 1,754 & 468 & 1,153 & 1,141 & 716 \\
\hline 1999 & 266 & 291 & 1,081 & 878 & 1,722 & 457 & 1,121 & 1,098 & 697 \\
\hline 2000 & 268 & 306 & 1,097 & 864 & 1,760 & 480 & 1,087 & 1,105 & 707 \\
\hline 2001 & 265 & 318 & 1,136 & 879 & 1,771 & 484 & 1,091 & 1,129 & 719 \\
\hline 2002 & 275 & 325 & 1,226 & 931 & 1,784 & 505 & 1,118 & 1,193 & 746 \\
\hline 2003 & 270 & 312 & 1,270 & 976 & 1,860 & 471 & 1,130 & 1,201 & 756 \\
\hline 2004 & 293 & 348 & 1,392 & 1,044 & 2,011 & 505 & 1,221 & 1,347 & 824 \\
\hline 2005 & 317 & 385 & 1,542 & 1,156 & 2,284 & 550 & 1,296 & 1,507 & 914 \\
\hline 2006 & 342 & 431 & 1,782 & 1,240 & 2,508 & 584 & 1,249 & 1,696 & 1,001 \\
\hline 2007 & 388 & 513 & 2,145 & 1,384 & 2,813 & 644 & 1,377 & 1,942 & 1,145 \\
\hline 2008 & 452 & 606 & 2,726 & 1,681 & 3,490 & 780 & 1,763 & 2,451 & 1,414 \\
\hline 2009 & 461 & 604 & 2,692 & 1,698 & 3,418 & 847 & 1,977 & 2,503 & 1,431 \\
\hline
\end{tabular}

Table continued on next page. 


\section{Appendix Table 4. Average Reported Value of Nebraska Farmland for Different Types of Land by Agricultural Statistics District, 1978-2020a (continued)}

\begin{tabular}{|c|c|c|c|c|c|c|c|c|c|}
\hline \multirow{2}{*}{ Year } & \multicolumn{9}{|c|}{ Agricultural Statistics District } \\
\hline & Northwest & North & Northeast & Central & East & Southwest & South & Southeast & State $^{b}$ \\
\hline & \multicolumn{9}{|c|}{ 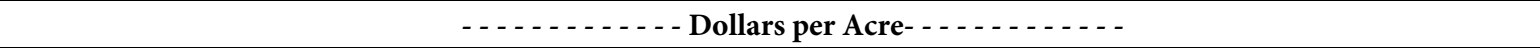 } \\
\hline \multicolumn{10}{|c|}{ All-Land Average ${ }^{d}$} \\
\hline 2010 & 463 & 598 & 2,898 & 1,748 & 3,762 & 870 & 2,029 & 2,596 & 1,503 \\
\hline 2011 & 520 & 706 & 3,624 & 2,183 & 4,225 & 991 & 2,535 & 3,160 & 1,833 \\
\hline 2012 & 635 & 875 & 4,975 & 2,945 & 6,080 & 1,335 & 3,355 & 4,280 & 2,425 \\
\hline 2013 & 715 & 1,055 & 6,165 & 3,750 & 7,185 & 1,750 & 4,460 & 5,400 & 3,040 \\
\hline 2014 & 855 & 1,220 & 6,460 & 4,195 & 7,285 & 1,985 & 4,815 & 6,185 & 3,315 \\
\hline 2015 & 860 & 1,330 & 6,140 & 3,955 & 7,100 & 2,065 & 4,625 & 5,990 & 3,250 \\
\hline 2016 & 820 & 1,245 & 5,980 & 3,780 & 6,990 & 1,960 & 4,255 & 5,675 & 3,115 \\
\hline 2017 & 755 & 1,170 & 5,505 & 3,385 & 6,395 & 1,745 & 3,875 & 4,880 & 2,820 \\
\hline 2018 & 715 & 1,090 & 5,395 & 3,165 & 6,240 & 1,650 & 3,750 & 4,815 & 2,720 \\
\hline 2019 & 680 & 1,050 & 5,230 & 3,090 & 6,185 & 1,565 & 3,535 & 4,700 & 2,645 \\
\hline 2020 & 685 & 1,090 & 5,370 & 3,180 & 6,495 & 1,550 & 3,620 & 4,865 & 2,725 \\
\hline
\end{tabular}

Source: ${ }^{a}$ Average reported from the UNL Nebraska Farm Real Estate Market Surveys, 1978-2020.

${ }^{\mathrm{b}}$ Weighted average based upon acreage in each land type.

${ }^{\mathrm{c}}$ Pivot not included in per acre value.

${ }^{\mathrm{d}}$ All-land average for the state may not conform to USDA series due to different acreage weighting. In addition, the USDA series includes farm buildings in the per acre estimates of value. 
Appendix Table 5. Historical Per Acre Value Range for Different Types and Quality Grades of Land in Nebraska by Agricultural Statistics District, 2016-2020 ${ }^{\mathrm{a}}$

\begin{tabular}{|c|c|c|c|c|c|c|c|c|c|c|}
\hline \multirow{3}{*}{ District and Type of Land } & \multicolumn{10}{|c|}{ Reported Value Per Acre } \\
\hline & \multicolumn{5}{|c|}{ Low Grade } & \multicolumn{5}{|c|}{ High Grade } \\
\hline & 2016 & 2017 & 2018 & 2019 & 2020 & 2016 & 2017 & 2018 & 2019 & 2020 \\
\hline & --- & & 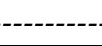 & 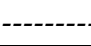 & Dollars & er Acre & $-----\cdot$ & ------ & ------ & --- \\
\hline \multicolumn{11}{|l|}{ Northwest: } \\
\hline Dry Crop (No Irr. Potential) & 555 & 540 & 485 & 475 & 440 & 965 & 935 & 910 & 820 & 795 \\
\hline Dry Crop (Irr. Pot.) & 600 & 565 & 525 & 505 & 530 & 910 & 895 & 880 & 870 & 875 \\
\hline Grazing (Tillable) & 485 & 450 & 430 & 420 & 440 & 620 & 615 & 600 & 605 & 615 \\
\hline Grazing (Nontillable) & 420 & 400 & 380 & 360 & 370 & 590 & 585 & 570 & 550 & 565 \\
\hline Hayland & 650 & 685 & 665 & 520 & 545 & 1,010 & 885 & 875 & 815 & 830 \\
\hline Gravity Irrigated & 2,610 & 2,250 & 1,900 & 1,710 & 1,570 & 3,890 & 3,475 & 3,220 & 2,980 & 2,865 \\
\hline Center Pivot Irrigated $^{\mathrm{b}}$ & 3,100 & 2,385 & 2,055 & 2,060 & 1,945 & 4,415 & 3,265 & 3,030 & 3,105 & 3,000 \\
\hline \multicolumn{11}{|l|}{ North: } \\
\hline Dry Crop (No Irr. Potential) & 1,565 & 1,430 & 1,330 & 1,285 & 1,225 & 2,220 & 2,080 & 1,945 & 1,845 & 1,880 \\
\hline Dry Crop (Irr. Pot.) & 1,910 & 1,810 & 1,740 & 1,715 & 1,735 & 2,685 & 2,450 & 2,305 & 2,265 & 2,310 \\
\hline Grazing (Tillable) & 1,120 & 1,035 & 995 & 945 & 955 & 1,775 & 1,425 & 1,375 & 1,265 & 1,300 \\
\hline Grazing (Nontillable) & 630 & 620 & 585 & 500 & 520 & 940 & 935 & 885 & 870 & 885 \\
\hline Hayland & 1,110 & 1,085 & 1,040 & 1,000 & 1,010 & 1,710 & 1,585 & 1,470 & 1,390 & 1,460 \\
\hline Gravity Irrigated & 2,870 & 2,800 & 2,715 & 2,700 & 2,815 & 4,520 & 4,265 & 4,170 & 4,080 & 4,390 \\
\hline Center Pivot Irrigated $^{\mathrm{b}}$ & 3,935 & 3,750 & 3,595 & 3,380 & 3,390 & 5,620 & 5,560 & 5,010 & 4,975 & 5,135 \\
\hline \multicolumn{11}{|l|}{ Northeast: } \\
\hline Dry Crop (No Irr. Potential) & 4,140 & 4,020 & 4,045 & 3,960 & 4,070 & 7,010 & 6,980 & 6,550 & 6,420 & 6,720 \\
\hline Dry Crop (Irr. Pot.) & 4,930 & 4,805 & 4,905 & 4,745 & 4,760 & 7,280 & 7,250 & 6,600 & 6,310 & 6,825 \\
\hline Grazing (Tillable) & 2,830 & 2,560 & 2,580 & 2,490 & 2,570 & 4,240 & 3,910 & 3,780 & 3,715 & 3,835 \\
\hline Grazing (Nontillable) & 1,935 & 1,820 & 1,705 & 1,680 & 1,685 & 2,865 & 2,860 & 2,830 & 2,670 & 2,730 \\
\hline Hayland & 2,995 & 2,520 & 2,485 & 2,225 & 2,290 & 4,305 & 3,825 & 3,755 & 3,630 & 3,815 \\
\hline Gravity Irrigated & 6,480 & 5,895 & 5,860 & 5,610 & 5,635 & 8,810 & 8,555 & 8,120 & 7,940 & 7,920 \\
\hline Center Pivot Irrigated $^{\mathrm{b}}$ & 7,015 & 6,350 & 6,140 & 5,910 & 6,170 & 9,240 & 8,875 & 8,295 & 8,240 & 8,465 \\
\hline \multicolumn{11}{|l|}{ Central: } \\
\hline Dry Crop (No Irr. Potential) & 2,490 & 2,105 & 2,060 & 2,030 & 2,200 & 3,940 & 3,160 & 3,080 & 3,155 & 3,330 \\
\hline Dry Crop (Irr. Pot.) & 2,970 & 2,520 & 2,435 & 2,380 & 2,510 & 4,400 & 3,640 & 3,540 & 3,515 & 3,690 \\
\hline Grazing (Tillable) & 2,250 & 1,600 & 1,530 & 1,500 & 1,525 & 2,930 & 2,445 & 2,220 & 2,175 & 2,350 \\
\hline Grazing (Nontillable) & 1,655 & 1,190 & 1,115 & 1,050 & 1,110 & 2,340 & 1,905 & 1,865 & 1,765 & 1,835 \\
\hline Hayland & 2,300 & 1,800 & 1,740 & 1,560 & 1,620 & 3,015 & 2,350 & 2,065 & 2,040 & 2,185 \\
\hline Gravity Irrigated & 5,240 & 5,205 & 4,885 & 4,875 & 4,760 & 7,575 & 6,925 & 6,285 & 6,415 & 6,410 \\
\hline Center Pivot Irrigated ${ }^{b}$ & 6,255 & 5,845 & 5,455 & 5,195 & 5,410 & 8,200 & 7,900 & 7,240 & 7,190 & 7,635 \\
\hline
\end{tabular}

Table continued on next page. 
Appendix Table 5. Historical Per Acre Value Range for Different Types and Quality Grades of Land in Nebraska by Agricultural Statistics District, 2016-2020 (continued)

\begin{tabular}{|c|c|c|c|c|c|c|c|c|c|c|}
\hline \multirow{3}{*}{ District and Type of land } & \multicolumn{10}{|c|}{ Reported Value Per Acre } \\
\hline & \multicolumn{5}{|c|}{ Low Grade } & \multicolumn{5}{|c|}{ High Grade } \\
\hline & 2016 & 2017 & 2018 & 2019 & 2020 & 2016 & 2017 & 2018 & 2019 & 2020 \\
\hline & --- & 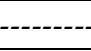 & 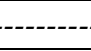 & 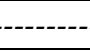 & Dollars & per Acre & 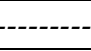 & 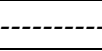 & 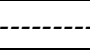 & --- \\
\hline \multicolumn{11}{|l|}{ East: } \\
\hline Dry Crop (No Irr. Potential) & 4,820 & 4,610 & 4,515 & 4,450 & 4,660 & 7,635 & 6,945 & 6,865 & 6,870 & 7,350 \\
\hline Dry Crop (Irr. Pot.) & 5,660 & 5,050 & 4,875 & 4,865 & 5,135 & 8,435 & 7,225 & 7,005 & 7,000 & 7,640 \\
\hline Grazing (Tillable) & 2,890 & 2,765 & 2,590 & 2,420 & 2,820 & 4,560 & 4,110 & 3,955 & 3,910 & 4,005 \\
\hline Grazing (Nontillable) & 2,005 & 1,925 & 1,900 & 1,885 & 2,045 & 3,290 & 2,950 & 2,635 & 2,600 & 2,760 \\
\hline Hayland & 2,440 & 2,310 & 2,225 & 2,415 & 2,445 & 3,675 & 3,565 & 3,615 & 3,335 & 3,310 \\
\hline Gravity Irrigated & 7,190 & 6,530 & 6,355 & 6,340 & 6,485 & 9,175 & 8,765 & 8,315 & 8,500 & 8,840 \\
\hline Center Pivot Irrigated ${ }^{\mathrm{b}}$ & 8,035 & 7,315 & 7,320 & 6,985 & 7,395 & 10,410 & 9,670 & 9,560 & 9,520 & 9,875 \\
\hline \multicolumn{11}{|l|}{ Southwest: } \\
\hline Dry Crop (No Irr. Potential) & 1,480 & 1,170 & 1,045 & 1,010 & 995 & 2,395 & 2,095 & 1,960 & 1,620 & 1,610 \\
\hline Dry Crop (Irr. Pot.) & 1,670 & 1,540 & 1,435 & 1,325 & 1,285 & 2,430 & 2,065 & 1,885 & 1,760 & 1,755 \\
\hline Grazing (Tillable) & 895 & 865 & 860 & 785 & 815 & 1,255 & 1,195 & 1,080 & 1,060 & 1,140 \\
\hline Grazing (Nontillable) & 825 & 650 & 625 & 610 & 620 & 1,160 & 965 & 870 & 820 & 835 \\
\hline Hayland & 1,285 & 1,205 & 1,150 & 1,040 & 1,095 & 1,935 & 1,620 & 1,465 & 1,490 & 1,545 \\
\hline Gravity Irrigated & 4,135 & 3,280 & 3,040 & 2,990 & 2,890 & 5,670 & 4,580 & 4,405 & 4,235 & 4,125 \\
\hline Center Pivot Irrigated ${ }^{\mathrm{b}}$ & 4,840 & 3,810 & 3,690 & 3,615 & 3,540 & 6,890 & 5,320 & 4,905 & 4,890 & 4,610 \\
\hline \multicolumn{11}{|l|}{ South: } \\
\hline Dry Crop (No Irr. Potential) & 2,405 & 2,205 & 2,180 & 2,165 & 2,315 & 4,440 & 3,625 & 3,315 & 3,300 & 3,475 \\
\hline Dry Crop (Irr. Pot.) & 2,940 & 2,740 & 2,890 & 2,810 & 2,900 & 4,685 & 4,400 & 4,150 & 4,140 & 4,170 \\
\hline Grazing (Tillable) & 1,580 & 1,450 & 1,505 & 1,485 & 1,460 & 2,440 & 2,370 & 2,150 & 2,110 & 2,180 \\
\hline Grazing (Nontillable) & 1,355 & 1,330 & 1,300 & 1,215 & 1,225 & 1,980 & 1,945 & 1,850 & 1,725 & 1,765 \\
\hline Hayland & 1,525 & 1,490 & 1,510 & 1,415 & 1,300 & 2,950 & 2,875 & 2,605 & 2,600 & 2,460 \\
\hline Gravity Irrigated & 4,585 & 4,420 & 4,225 & 4,185 & 4,310 & 7,970 & 7,060 & 6,725 & 6,520 & 6,570 \\
\hline Center Pivot Irrigated ${ }^{\mathrm{b}}$ & 5,710 & 5,530 & 5,400 & 5,625 & 5,580 & 8,355 & 7,840 & 7,645 & 7,395 & 7,350 \\
\hline \multicolumn{11}{|l|}{ Southeast: } \\
\hline Dry Crop (No Irr. Potential) & 3,305 & 3,075 & 3,005 & 2,940 & 3,130 & 5,910 & 5,060 & 5,095 & 5,100 & 5,490 \\
\hline Dry Crop (Irr. Pot.) & 4,310 & 4,030 & 3,920 & 3,905 & 4,055 & 7,635 & 6,315 & 6,195 & 6,175 & 6,320 \\
\hline Grazing (Tillable) & 2,580 & 2,305 & 2,190 & 2,140 & 2,330 & 3,430 & 3,195 & 3,270 & 3,125 & 3,495 \\
\hline Grazing (Nontillable) & 1,735 & 1,900 & 1,720 & 1,740 & 1,810 & 2,630 & 2,190 & 2,175 & 2,120 & 2,295 \\
\hline Hayland & 2,330 & 2,290 & 2,190 & 2,025 & 2,080 & 3,290 & 3,060 & 3,270 & 3,315 & 3,335 \\
\hline Gravity Irrigated & 6,800 & 5,500 & 4,890 & 4,870 & 5,050 & 8,525 & 7,140 & 7,125 & 7,120 & 7,430 \\
\hline Center Pivot Irrigated ${ }^{\mathrm{b}}$ & 7,400 & 6,490 & 6,230 & 6,105 & 6,420 & 9,865 & 8,330 & 8,495 & 8,430 & 8,745 \\
\hline
\end{tabular}

Source: ${ }^{\text {a } U N L ~ N e b r a s k a ~ F a r m ~ R e a l ~ E s t a t e ~ M a r k e t ~ S u r v e y s, ~ 2016-2020 . ~}$

${ }^{\mathrm{b}}$ Pivot not included in per acre value. 
Appendix Table 6. Estimated Annual Net Rates of Return to Nebraska Farmland for Different Types of Land by Agricultural Statistics District, 1990-2020

\begin{tabular}{|c|c|c|c|c|c|c|c|c|c|}
\hline \multirow{2}{*}{ Year } & \multicolumn{9}{|c|}{ Agricultural Statistics District } \\
\hline & Northwest & North & Northeast & Central & East & Southwest & South & Southeast & State \\
\hline
\end{tabular}

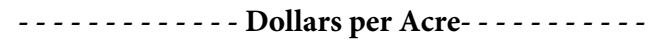

Dryland Cropland

\begin{tabular}{|c|c|c|c|c|c|c|c|c|c|}
\hline 1990 & 6.2 & 6.3 & 5.9 & 6.4 & 5.9 & 4.7 & 6.1 & 6.3 & 6.0 \\
\hline 1991 & 5.9 & 5.0 & 6.0 & 5.9 & 5.8 & 4.7 & 6.1 & 5.8 & 5.7 \\
\hline 1992 & 4.8 & 5.0 & 5.6 & 5.9 & 5.7 & 5.6 & 5.2 & 6.1 & 5.5 \\
\hline 1993 & 5.0 & 4.3 & 5.8 & 5.7 & 5.3 & 5.3 & 6.1 & 5.2 & 5.4 \\
\hline 1994 & 4.5 & 5.2 & 6.0 & 5.4 & 5.2 & 5.2 & 5.3 & 5.4 & 5.3 \\
\hline 1995 & 4.2 & 6.0 & 6.2 & 5.3 & 5.2 & 5.1 & 5.4 & 5.0 & 5.3 \\
\hline 1996 & 4.1 & 5.0 & 6.3 & 5.6 & 5.0 & 5.3 & 5.5 & 5.2 & 5.3 \\
\hline 1997 & 5.1 & 5.8 & 6.4 & 5.6 & 5.3 & 5.3 & 5.4 & 5.4 & 5.5 \\
\hline 1998 & 4.5 & 5.5 & 5.8 & 5.3 & 4.8 & 4.8 & 5.4 & 5.0 & 5.1 \\
\hline 1999 & 4.3 & 4.9 & 5.4 & 5.1 & 4.5 & 3.9 & 4.5 & 4.9 & 4.7 \\
\hline 2000 & 4.0 & 5.2 & 5.4 & 5.1 & 4.7 & 4.5 & 4.7 & 5.0 & 4.8 \\
\hline 2001 & 4.1 & 5.3 & 5.5 & 5.0 & 4.6 & 4.3 & 4.6 & 4.7 & 4.8 \\
\hline 2002 & 4.0 & 4.6 & 5.3 & 5.1 & 4.5 & 4.7 & 4.6 & 4.9 & 4.7 \\
\hline 2003 & 3.6 & 4.5 & 4.8 & 4.6 & 4.1 & 4.1 & 4.7 & 4.4 & 4.4 \\
\hline 2004 & 3.5 & 4.4 & 4.5 & 4.3 & 3.8 & 3.9 & 4.4 & 4.6 & 4.2 \\
\hline 2005 & 3.6 & 3.9 & 4.2 & 4.5 & 3.5 & 4.0 & 4.6 & 4.4 & 4.1 \\
\hline 2006 & 3.5 & 4.4 & 3.6 & 4.2 & 3.4 & 3.8 & 4.6 & 4.1 & 4.0 \\
\hline 2007 & 4.1 & 4.4 & 4.3 & 4.6 & 3.4 & 3.7 & 4.8 & 4.0 & 4.1 \\
\hline 2008 & 4.5 & 4.8 & 4.4 & 4.7 & 3.9 & 4.0 & 5.0 & 4.4 & 4.5 \\
\hline 2009 & 4.0 & 4.0 & 4.0 & 4.3 & 3.5 & 3.5 & 4.1 & 3.8 & 3.9 \\
\hline 2010 & 4.1 & 3.5 & 4.1 & 3.7 & 3.2 & 4.1 & 4.0 & 3.7 & 3.8 \\
\hline 2011 & 3.8 & 3.7 & 3.8 & 3.8 & 3.5 & 3.5 & 4.0 & 3.5 & 3.7 \\
\hline 2012 & 4.0 & 4.0 & 3.3 & 3.7 & 3.2 & 3.2 & 3.3 & 3.2 & 3.5 \\
\hline 2013 & 3.5 & 2.9 & 3.3 & 2.8 & 2.8 & 3.0 & 1.9 & 2.7 & 2.9 \\
\hline 2014 & 3.5 & 2.4 & 3.0 & 2.5 & 3.0 & 2.6 & 2.2 & 2.5 & 2.8 \\
\hline 2015 & 3.4 & 2.4 & 2.9 & 2.4 & 2.6 & 2.5 & 2.3 & 2.4 & 2.6 \\
\hline 2016 & 3.6 & 2.5 & 3.0 & 2.7 & 2.6 & 2.4 & 2.2 & 2.5 & 2.7 \\
\hline 2017 & 3.5 & 2.4 & 2.8 & 2.5 & 2.3 & 2.5 & 2.2 & 2.4 & 2.6 \\
\hline 2018 & 3.3 & 2.5 & 2.7 & 2.6 & 2.2 & 2.4 & 2.4 & 2.3 & 2.5 \\
\hline 2019 & 3.1 & 2.4 & 2.6 & 2.5 & 2.4 & 2.2 & 2.3 & 2.2 & 2.5 \\
\hline 2020 & 2.9 & 2.3 & 2.6 & 2.4 & 2.3 & 2.0 & 2.2 & 2.4 & 2.4 \\
\hline
\end{tabular}

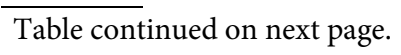


Appendix Table 6. Estimated Annual Net Rates of Return to Nebraska Farmland for Different Types of Land by Agricultural Statistics District, 1990-2020 ${ }^{\text {ab }}$ (continued)

\begin{tabular}{|c|c|c|c|c|c|c|c|c|c|}
\hline \multirow{2}{*}{ Year } & \multicolumn{8}{|c|}{ Agricultural Statistics District } \\
\cline { 2 - 9 } & Northwest & North & Northeast & Central & East & Southwest & South & Southeast & State \\
\hline
\end{tabular}

- . . . . . . . . - Dollars per Acre- . . . . . . . . . -

Irrigated Cropland

\begin{tabular}{|c|c|c|c|c|c|c|c|c|c|}
\hline 1990 & 8.3 & 9.3 & 6.9 & 6.8 & 6.7 & 6.3 & 6.3 & 6.0 & 7.1 \\
\hline 1991 & 8.7 & 8.0 & 6.8 & 6.5 & 6.4 & 6.4 & 6.2 & 5.9 & 6.9 \\
\hline 1992 & 6.8 & 6.5 & 6.6 & 6.6 & 6.0 & 6.5 & 6.0 & 6.1 & 6.4 \\
\hline 1993 & 6.6 & 6.0 & 6.5 & 6.1 & 5.7 & 6.5 & 6.5 & 6.0 & 6.2 \\
\hline 1994 & 6.9 & 6.5 & 6.3 & 6.3 & 5.6 & 6.2 & 5.7 & 5.7 & 6.2 \\
\hline 1995 & 6.6 & 6.8 & 6.5 & 5.9 & 5.3 & 5.9 & 6.0 & 5.0 & 6.0 \\
\hline 1996 & 6.7 & 6.3 & 6.9 & 5.8 & 5.2 & 6.5 & 6.2 & 5.4 & 6.1 \\
\hline 1997 & 7.2 & 7.0 & 7.0 & 6.0 & 5.3 & 6.7 & 6.3 & 5.7 & 6.4 \\
\hline 1998 & 6.7 & 6.7 & 6.0 & 5.8 & 5.0 & 6.6 & 5.7 & 5.4 & 6.0 \\
\hline 1999 & 6.0 & 5.9 & 5.9 & 5.3 & 4.6 & 6.1 & 4.9 & 5.0 & 5.5 \\
\hline 2000 & 6.0 & 6.2 & 6.0 & 5.6 & 5.0 & 6.3 & 5.5 & 5.0 & 5.7 \\
\hline 2001 & 5.6 & 6.2 & 5.9 & 5.4 & 4.9 & 6.5 & 5.2 & 5.0 & 5.6 \\
\hline 2002 & 5.4 & 5.9 & 5.5 & 5.3 & 4.5 & 6.2 & 5.3 & 5.1 & 5.4 \\
\hline 2003 & 5.3 & 5.8 & 5.2 & 5.2 & 4.4 & 6.3 & 5.4 & 5.1 & 5.3 \\
\hline 2004 & 5.3 & 6.1 & 5.2 & 5.2 & 4.7 & 5.6 & 5.3 & 5.3 & 5.3 \\
\hline 2005 & 5.9 & 5.9 & 4.9 & 5.0 & 4.0 & 5.6 & 5.4 & 5.0 & 5.2 \\
\hline 2006 & 5.5 & 5.8 & 4.2 & 4.9 & 3.7 & 5.4 & 5.3 & 4.4 & 4.9 \\
\hline 2007 & 5.4 & 5.9 & 4.7 & 5.0 & 3.9 & 6.0 & 5.6 & 4.9 & 5.0 \\
\hline 2008 & 6.0 & 6.0 & 4.9 & 5.2 & 4.2 & 5.8 & 5.6 & 5.1 & 5.4 \\
\hline 2009 & 5.8 & 5.0 & 4.8 & 4.7 & 3.9 & 4.8 & 4.9 & 4.6 & 4.8 \\
\hline 2010 & 5.2 & 4.7 & 4.7 & 4.6 & 3.5 & 5.0 & 4.2 & 4.2 & 4.4 \\
\hline 2011 & 5.1 & 4.5 & 4.3 & 4.4 & 3.9 & 4.8 & 4.5 & 4.2 & 4.5 \\
\hline 2012 & 4.9 & 4.8 & 3.7 & 3.6 & 3.3 & 4.0 & 3.3 & 3.6 & 3.9 \\
\hline 2013 & 4.4 & 3.5 & 3.8 & 3.1 & 3.3 & 3.7 & 2.8 & 3.0 & 3.4 \\
\hline 2014 & 4.6 & 2.7 & 3.6 & 2.5 & 3.4 & 3.4 & 2.4 & 3.1 & 3.2 \\
\hline 2015 & 4.4 & 2.6 & 3.5 & 2.4 & 3.0 & 3.3 & 2.4 & 2.8 & 3.1 \\
\hline 2016 & 4.3 & 2.5 & 3.6 & 2.6 & 2.9 & 3.2 & 2.3 & 2.8 & 3.0 \\
\hline 2017 & 4.0 & 2.6 & 3.4 & 2.7 & 2.8 & 3.1 & 2.4 & 2.7 & 3.0 \\
\hline 2018 & 3.9 & 2.7 & 3.2 & 2.5 & 2.7 & 3.1 & 2.5 & 2.6 & 2.9 \\
\hline 2019 & 3.6 & 2.6 & 3.1 & 2.4 & 2.5 & 2.9 & 2.4 & 2.5 & 2.8 \\
\hline 2020 & 3.3 & 2.4 & 3.0 & 2.3 & 2.4 & 2.7 & 2.3 & 2.5 & 2.6 \\
\hline
\end{tabular}

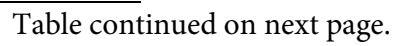


Appendix Table 6. Estimated Annual Net Rates of Return to Nebraska Farmland for Different Types of Land by Agricultural Statistics District, 1990-2020 ${ }^{\text {ab }}$ (continued)

\begin{tabular}{|c|c|c|c|c|c|c|c|c|c|}
\hline \multirow{2}{*}{ Year } & \multicolumn{9}{|c|}{ Agricultural Statistics District } \\
\hline & Northwest & North & Northeast & Central & East & Southwest & South & Southeast & State \\
\hline
\end{tabular}

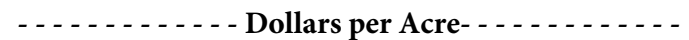

\section{Grazing Land}

\begin{tabular}{|c|c|c|c|c|c|c|c|c|c|}
\hline 1990 & 4.0 & 5.8 & 4.6 & 4.9 & 5.0 & 4.5 & 5.4 & 5.0 & 4.9 \\
\hline 1991 & 5.5 & 5.9 & 5.4 & 5.0 & 5.3 & 5.8 & 5.5 & 5.5 & 5.4 \\
\hline 1992 & 4.0 & 5.3 & 4.9 & 4.6 & 4.4 & 5.1 & 5.0 & 5.0 & 4.8 \\
\hline 1993 & 4.3 & 4.6 & 5.0 & 4.6 & 4.3 & 4.6 & 4.5 & 4.6 & 4.6 \\
\hline 1994 & 4.7 & 4.5 & 5.1 & 4.4 & 4.3 & 4.7 & 4.1 & 4.5 & 4.5 \\
\hline 1995 & 3.7 & 4.7 & 4.9 & 4.0 & 4.2 & 4.5 & 4.2 & 4.0 & 4.3 \\
\hline 1996 & 3.8 & 4.3 & 4.9 & 4.3 & 4.0 & 4.3 & 3.8 & 4.1 & 4.2 \\
\hline 1997 & 3.6 & 4.3 & 4.9 & 4.5 & 4.0 & 4.0 & 3.6 & 4.2 & 4.1 \\
\hline 1998 & 3.4 & 4.2 & 4.6 & 4.1 & 3.9 & 4.2 & 4.0 & 3.8 & 4.0 \\
\hline 1999 & 3.1 & 3.5 & 4.4 & 4.2 & 3.6 & 3.2 & 3.6 & 3.9 & 3.7 \\
\hline 2000 & 3.3 & 4.4 & 4.6 & 3.7 & 3.8 & 3.6 & 4.0 & 4.1 & 3.9 \\
\hline 2001 & 2.9 & 4.0 & 4.3 & 3.9 & 4.0 & 3.4 & 3.5 & 4.1 & 3.8 \\
\hline 2002 & 2.8 & 4.1 & 4.4 & 3.8 & 3.7 & 4.0 & 3.8 & 4.1 & 3.8 \\
\hline 2003 & 2.4 & 3.3 & 3.8 & 3.3 & 3.4 & 3.4 & 3.9 & 3.8 & 3.4 \\
\hline 2004 & 2.8 & 3.1 & 3.6 & 3.3 & 3.7 & 3.3 & 3.4 & 4.1 & 3.4 \\
\hline 2005 & 2.6 & 3.3 & 3.7 & 3.8 & 2.9 & 3.1 & 3.6 & 4.3 & 3.4 \\
\hline 2006 & 2.7 & 3.1 & 3.0 & 3.6 & 3.0 & 3.1 & 3.7 & 3.8 & 3.3 \\
\hline 2007 & 2.3 & 2.5 & 3.0 & 2.9 & 2.9 & 2.8 & 3.5 & 3.0 & 2.9 \\
\hline 2008 & 2.8 & 3.1 & 3.3 & 2.9 & 3.4 & 2.9 & 3.3 & 3.6 & 3.2 \\
\hline 2009 & 2.6 & 2.7 & 3.0 & 2.9 & 2.5 & 2.5 & 2.9 & 3.1 & 2.8 \\
\hline 2010 & 2.0 & 2.5 & 3.1 & 2.1 & 2.3 & 2.9 & 3.0 & 2.9 & 2.6 \\
\hline 2011 & 2.0 & 2.9 & 2.6 & 2.5 & 2.7 & 2.5 & 3.0 & 2.5 & 2.6 \\
\hline 2012 & 2.0 & 2.4 & 2.4 & 2.4 & 2.0 & 2.2 & 3.1 & 2.2 & 2.4 \\
\hline 2013 & 1.9 & 2.3 & 2.4 & 1.6 & 2.0 & 1.8 & 1.7 & 1.7 & 1.9 \\
\hline 2014 & 2.1 & 2.0 & 2.1 & 1.7 & 1.9 & 2.1 & 1.7 & 1.4 & 1.7 \\
\hline 2015 & 2.3 & 2.6 & 2.7 & 2.1 & 2.2 & 2.6 & 2.2 & 1.7 & 2.3 \\
\hline 2016 & 2.2 & 2.7 & 2.6 & 2.1 & 2.0 & 2.3 & 2.1 & 1.5 & 2.2 \\
\hline 2017 & 2.1 & 2.5 & 2.4 & 2.0 & 1.7 & 2.1 & 1.9 & 1.6 & 2.0 \\
\hline 2018 & 2.1 & 2.6 & 2.2 & 1.9 & 1.8 & 2.0 & 1.8 & 1.7 & 2.0 \\
\hline 2019 & 2.0 & 2.3 & 2.1 & 1.7 & 1.8 & 1.9 & 2.0 & 1.6 & 1.9 \\
\hline 2020 & 1.9 & 2.2 & 2.0 & 1.5 & 1.9 & 1.8 & 2.0 & 1.7 & 1.9 \\
\hline
\end{tabular}

Source: ${ }^{a}$ Panel members reported annual estimates of net rates of return in the annual UNL Nebraska Farm Real Estate Market Surveys, 1990-2020.

${ }^{\mathrm{b}}$ Panel members reported estimates of annual net returns as percentage rates of current land values. Real estate appraisers refer to this percentage as the market-derived capitalization rate. 
Appendix Table 7. Historical Average Cash Rental Rates of Nebraska Farmland for Different Types of Land by Agricultural Statistics District, 1981-2020 ${ }^{\mathrm{a}}$

\begin{tabular}{|c|c|c|c|c|c|c|c|c|}
\hline \multirow{2}{*}{$\begin{array}{c}\text { Type of } \\
\text { Land and } \\
\text { Year }\end{array}$} & \multicolumn{7}{|c|}{ Agricultural Statistics District } \\
\cline { 2 - 8 } & Northwest & North & Northeast & Central & East & Southwest & South & Southeast \\
\hline
\end{tabular}

\section{Dryland Cropland}

\begin{tabular}{|c|c|c|c|c|c|c|c|c|}
\hline 1981 & $\mathrm{~b}$ & $\mathrm{~b}$ & 60 & 43 & 68 & 35 & 38 & 55 \\
\hline 1982 & $\mathrm{~b}$ & b & 67 & 38 & 71 & 34 & 38 & 60 \\
\hline 1983 & $\mathrm{~b}$ & b & 63 & 43 & 66 & 25 & 41 & 57 \\
\hline 1984 & $\mathrm{~b}$ & b & 63 & 41 & 72 & 29 & 44 & 57 \\
\hline 1985 & $\mathrm{~b}$ & b & 55 & 38 & 65 & 26 & 40 & 50 \\
\hline 1986 & $\mathrm{~b}$ & b & 52 & 29 & 58 & 25 & 35 & 45 \\
\hline 1987 & $\mathrm{~b}$ & b & 55 & 29 & 58 & 23 & 35 & 45 \\
\hline 1988 & $\mathrm{~b}$ & b & 58 & 35 & 62 & 25 & 38 & 48 \\
\hline 1989 & $\mathrm{~b}$ & b & 65 & 42 & 70 & 26 & 43 & 52 \\
\hline 1990 & $b$ & b & 65 & 44 & 72 & 31 & 41 & 54 \\
\hline 1991 & $\mathrm{~b}$ & b & 64 & 45 & 73 & 27 & 41 & 58 \\
\hline 1992 & $\mathrm{~b}$ & b & 60 & 47 & 73 & 28 & 43 & 57 \\
\hline 1993 & 24 & 28 & 65 & 46 & 74 & 28 & 47 & 60 \\
\hline 1994 & $\mathrm{~b}$ & 33 & 66 & 44 & 79 & 32 & 45 & 62 \\
\hline 1995 & 21 & 36 & 69 & 48 & 79 & 29 & 46 & 61 \\
\hline 1996 & 21 & 35 & 69 & 49 & 81 & 31 & 47 & 62 \\
\hline 1997 & 22 & 38 & 74 & 53 & 85 & 32 & 49 & 65 \\
\hline 1998 & 22 & 39 & 79 & 53 & 88 & 32 & 51 & 70 \\
\hline 1999 & 21 & 38 & 79 & 51 & 85 & 30 & 49 & 67 \\
\hline 2000 & 20 & 38 & 79 & 53 & 86 & 29 & 49 & 66 \\
\hline 2001 & 20 & 37 & 78 & 53 & 87 & 29 & 51 & 64 \\
\hline 2002 & 21 & 38 & 85 & 54 & 87 & 31 & 53 & 69 \\
\hline 2003 & 22 & 32 & 86 & 59 & 89 & 32 & 52 & 71 \\
\hline 2004 & 22 & 35 & 91 & 60 & 94 & 33 & 55 & 75 \\
\hline 2005 & 24 & 37 & 92 & 62 & 99 & 33 & 56 & 79 \\
\hline 2006 & 24 & 38 & 97 & 63 & 102 & 31 & 52 & 83 \\
\hline 2007 & 26 & 41 & 109 & 71 & 113 & 34 & 56 & 93 \\
\hline 2008 & 33 & 50 & 134 & 86 & 135 & 40 & 69 & 113 \\
\hline 2009 & 29 & 49 & 136 & 81 & 136 & 38 & 72 & 112 \\
\hline
\end{tabular}

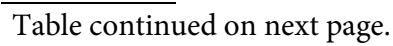


Appendix Table 7. Historical Average Cash Rental Rates of Nebraska Farmland for Different Types of Land by Agricultural Statistics District, 1981-2020ª (continued)

\begin{tabular}{|c|c|c|c|c|c|c|c|c|}
\hline \multirow{2}{*}{$\begin{array}{c}\text { Type of } \\
\text { Land and } \\
\text { Year }\end{array}$} & \multicolumn{7}{|c|}{ Agricultural Statistics District } \\
\cline { 2 - 8 } & Northwest & North & Northeast & Central & East & Southwest & South & Southeast \\
\hline
\end{tabular}

Dryland Cropland

$\begin{array}{lrrrrrrrr}\mathbf{2 0 1 0} & 31 & \text { b } & 144 & 83 & 146 & 41 & 74 & 116 \\ \mathbf{2 0 1 1} & 35 & 52 & 180 & 94 & 178 & 48 & 96 & 142 \\ \mathbf{2 0 1 2} & 39 & 55 & 212 & 110 & 204 & 56 & 116 & 162 \\ \mathbf{2 0 1 3} & 40 & 57 & 234 & 118 & 219 & 59 & 125 & 174 \\ \mathbf{2 0 1 4} & 40 & 70 & 245 & 110 & 215 & 50 & 90 & 175 \\ \mathbf{2 0 1 5} & 35 & 65 & 235 & 105 & 205 & 45 & 85 & 170 \\ \mathbf{2 0 1 6} & 32 & 60 & 225 & 96 & 200 & 42 & 80 & 165 \\ \mathbf{2 0 1 7} & 29 & 55 & 215 & 88 & 195 & 39 & 72 & 155 \\ \mathbf{2 0 1 8} & 28 & 53 & 210 & 89 & 190 & 41 & 76 & 160 \\ \mathbf{2 0 1 9} & 27 & 50 & 205 & 84 & 200 & 38 & 73 & 155 \\ \mathbf{2 0 2 0} & 28 & 52 & 215 & 91 & 205 & 37 & 76 & 165\end{array}$

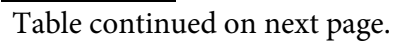


Appendix Table 7. Historical Average Cash Rental Rates of Nebraska Farmland for Different Types of Land by Agricultural Statistics District, 1981-2019 ${ }^{a}$ (continued)

\begin{tabular}{|c|c|c|c|c|c|c|c|c|}
\hline \multirow{2}{*}{$\begin{array}{c}\text { Type of } \\
\text { Land and } \\
\text { Year }\end{array}$} & \multicolumn{7}{|c|}{ Agricultural Statistics District } \\
\cline { 2 - 9 } & Northwest & North & Northeast & Central & East & Southwest & South & Southeast \\
\hline
\end{tabular}

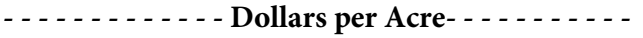

Gravity Irrigated Cropland

\begin{tabular}{|c|c|c|c|c|c|c|c|c|}
\hline 1981 & b & $\mathrm{b}$ & 107 & 114 & 114 & 97 & 117 & 115 \\
\hline 1982 & 100 & 96 & $\mathrm{~b}$ & 119 & 116 & 97 & 115 & 115 \\
\hline 1983 & 93 & 95 & $\mathrm{~b}$ & 110 & 111 & 92 & 110 & 112 \\
\hline 1984 & 110 & 95 & 100 & 115 & 113 & 89 & 115 & 113 \\
\hline 1985 & 91 & 90 & 89 & 105 & 99 & 80 & 103 & 98 \\
\hline 1986 & 78 & 73 & 80 & 90 & 97 & 77 & 93 & 88 \\
\hline 1987 & b & 67 & 83 & 88 & 96 & 76 & 91 & 85 \\
\hline 1988 & b & 70 & 94 & 94 & 103 & 76 & 95 & 93 \\
\hline 1989 & b & 87 & 102 & 111 & 115 & 88 & 106 & 97 \\
\hline 1990 & 74 & 88 & 99 & 113 & 113 & 96 & 106 & 104 \\
\hline 1991 & 84 & 95 & 99 & 119 & 118 & 101 & 112 & 103 \\
\hline 1992 & 83 & 101 & 98 & 109 & 119 & 99 & 118 & 109 \\
\hline 1993 & 77 & 93 & 107 & 118 & 124 & 94 & 124 & 114 \\
\hline 1994 & 83 & 100 & 110 & 121 & 131 & 107 & 124 & 122 \\
\hline 1995 & 80 & 98 & 108 & 120 & 127 & 101 & 123 & 116 \\
\hline 1996 & 78 & 99 & 108 & 124 & 127 & 104 & 126 & 118 \\
\hline 1997 & 80 & 105 & 114 & 129 & 136 & 108 & 132 & 125 \\
\hline 1998 & 91 & 105 & 116 & 129 & 136 & 103 & 133 & 128 \\
\hline 1999 & 85 & 102 & 111 & 123 & 133 & 98 & 130 & 119 \\
\hline 2000 & 82 & 98 & 118 & 123 & 133 & 100 & 128 & 120 \\
\hline 2001 & 84 & 98 & 122 & 128 & 133 & 106 & 127 & 126 \\
\hline 2002 & 84 & 100 & 124 & 128 & 136 & 104 & 128 & 131 \\
\hline 2003 & 86 & 98 & 120 & 129 & 135 & 97 & 125 & 128 \\
\hline 2004 & 88 & 105 & 129 & 134 & 138 & 101 & 128 & 131 \\
\hline 2005 & 94 & 104 & 133 & 134 & 142 & 105 & 130 & 134 \\
\hline 2006 & 97 & 105 & 135 & 135 & 144 & 101 & 130 & 138 \\
\hline 2007 & 103 & 115 & 156 & 150 & 160 & 107 & 139 & 152 \\
\hline 2008 & 126 & 142 & 188 & 173 & 189 & 116 & 168 & 185 \\
\hline 2009 & 110 & 139 & 190 & 169 & 196 & 117 & 171 & 187 \\
\hline
\end{tabular}

Table continued on next page. 
Appendix Table 7. Historical Average Cash Rental Rates of Nebraska Farmland for Different Types of Land by Agricultural Statistics District, 1981-2020 ${ }^{a}$ (continued)

\begin{tabular}{|c|c|c|c|c|c|c|c|c|}
\hline \multirow{2}{*}{$\begin{array}{c}\text { Type of } \\
\text { Land and } \\
\text { Year }\end{array}$} & \multicolumn{7}{|c|}{ Agricultural Statistics District } \\
\cline { 2 - 8 } & Northwest & North & Northeast & Central & East & Southwest & South & Southeast \\
\hline
\end{tabular}

Gravity Irrigated Cropland

$\begin{array}{rrrrrrrrr}\mathbf{2 0 1 0} & 115 & \text { b } & 207 & 174 & 208 & 130 & 183 & 197 \\ \mathbf{2 0 1 1} & \text { b } & \text { b } & 248 & 197 & 259 & \text { b } & 211 & 236 \\ \mathbf{2 0 1 2} & \text { b } & \text { b } & 285 & 230 & 297 & 184 & 247 & 267 \\ \mathbf{2 0 1 3} & \text { b } & \text { b } & 319 & 260 & 320 & 210 & 275 & 299 \\ \mathbf{2 0 1 4} & 145 & 205 & 290 & 250 & 315 & 190 & 225 & 295 \\ \mathbf{2 0 1 5} & 135 & 195 & 285 & 235 & 300 & 185 & 220 & 255 \\ \mathbf{2 0 1 6} & 125 & 175 & 275 & 230 & 285 & 180 & 215 & 250 \\ \mathbf{2 0 1 7} & 120 & 165 & 255 & 220 & 260 & 170 & 205 & 235 \\ \mathbf{2 0 1 8} & 115 & 170 & 250 & 205 & 255 & 165 & 200 & 225 \\ \mathbf{2 0 1 9} & 110 & 165 & 255 & 195 & 245 & 155 & 190 & 220 \\ \mathbf{2 0 2 0} & 105 & 170 & 260 & 205 & 255 & 160 & 205 & 230\end{array}$

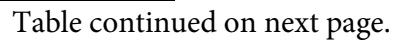


Appendix Table 7. Historical Average Cash Rental Rates of Nebraska Farmland for Different Types of Land by Agricultural Statistics District, 1981-2020 ${ }^{a}$ (continued)

\begin{tabular}{|c|c|c|c|c|c|c|c|c|}
\hline \multirow{2}{*}{$\begin{array}{c}\text { Type of } \\
\text { Land and } \\
\text { Year }\end{array}$} & \multicolumn{7}{|c|}{ Agricultural Statistics District } \\
\cline { 2 - 9 } & Northwest & North & Northeast & Central & East & Southwest & South & Southeast \\
\hline
\end{tabular}

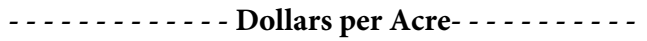

Center Pivot Irrigated Cropland

\begin{tabular}{|c|c|c|c|c|c|c|c|c|}
\hline 1981 & b & 71 & 117 & 102 & 118 & 91 & 126 & 119 \\
\hline 1982 & 98 & 82 & 116 & 108 & 120 & 93 & 127 & 119 \\
\hline 1983 & 90 & 86 & 101 & 100 & 114 & 83 & 117 & 116 \\
\hline 1984 & 98 & 81 & 99 & 101 & 118 & 80 & 120 & 114 \\
\hline 1985 & $\mathrm{~b}$ & 69 & 93 & 90 & 104 & 81 & 111 & 96 \\
\hline 1986 & b & 60 & 86 & 75 & 99 & 69 & 91 & 86 \\
\hline 1987 & b & 62 & 83 & 77 & 97 & 66 & 82 & 86 \\
\hline 1988 & b & 67 & 91 & 82 & 100 & 73 & 89 & 93 \\
\hline 1989 & b & 88 & 99 & 98 & 110 & 81 & 101 & 100 \\
\hline 1990 & 77 & 97 & 106 & 99 & 114 & 91 & 104 & 108 \\
\hline 1991 & 85 & 98 & 108 & 109 & 120 & 94 & 115 & 110 \\
\hline 1992 & 79 & 96 & 105 & 102 & 120 & 92 & 119 & 113 \\
\hline 1993 & 79 & 83 & 107 & 108 & 124 & 93 & 124 & 114 \\
\hline 1994 & 85 & 104 & 115 & 116 & 130 & 98 & 126 & 122 \\
\hline 1995 & 86 & 100 & 118 & 117 & 128 & 101 & 127 & 122 \\
\hline 1996 & 80 & 107 & 117 & 119 & 130 & 105 & 128 & 124 \\
\hline 1997 & 90 & 115 & 124 & 130 & 142 & 110 & 138 & 132 \\
\hline 1998 & 95 & 115 & 125 & 132 & 143 & 111 & 138 & 132 \\
\hline 1999 & 90 & 109 & 122 & 124 & 143 & 110 & 136 & 127 \\
\hline 2000 & 93 & 105 & 125 & 124 & 144 & 111 & 135 & 129 \\
\hline 2001 & 94 & 106 & 130 & 129 & 144 & 113 & 132 & 134 \\
\hline 2002 & 96 & 108 & 132 & 131 & 146 & 115 & 133 & 135 \\
\hline 2003 & 97 & 105 & 137 & 134 & 145 & 115 & 135 & 138 \\
\hline 2004 & 97 & 114 & 144 & 139 & 151 & 117 & 139 & 143 \\
\hline 2005 & 107 & 119 & 142 & 139 & 155 & 121 & 143 & 147 \\
\hline 2006 & 102 & 120 & 147 & 140 & 157 & 120 & 139 & 152 \\
\hline 2007 & 118 & 136 & 173 & 156 & 176 & 128 & 154 & 169 \\
\hline 2008 & 140 & 159 & 208 & 185 & 211 & 139 & 183 & 198 \\
\hline 2009 & 135 & 158 & 207 & 182 & 216 & 160 & 190 & 208 \\
\hline
\end{tabular}

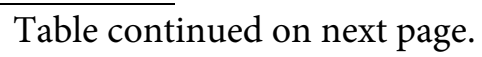


Appendix Table 7. Historical Average Cash Rental Rates of Nebraska Farmland for Different Types of Land by Agricultural Statistics District, 1981-2020 ${ }^{a}$ (continued)

\begin{tabular}{|c|c|c|c|c|c|c|c|c|}
\hline \multirow{2}{*}{$\begin{array}{c}\text { Type of } \\
\text { Land and } \\
\text { Year }\end{array}$} & \multicolumn{7}{|c|}{ Agricultural Statistics District } \\
\cline { 2 - 8 } & Northwest & North & Northeast & Central & East & Southwest & South & Southeast \\
\hline
\end{tabular}

Center Pivot Irrigated Cropland

$\begin{array}{lllllllll}\mathbf{2 0 1 0} & 140 & 168 & 232 & 193 & 234 & 162 & 198 & 214 \\ \mathbf{2 0 1 1} & 171 & 195 & 279 & 221 & 273 & 193 & 233 & 257 \\ \mathbf{2 0 1 2} & 200 & 234 & 330 & 256 & 315 & 236 & 279 & 305 \\ \mathbf{2 0 1 3} & 225 & 265 & 379 & 287 & 355 & 269 & 313 & 345 \\ \mathbf{2 0 1 4} & 200 & 250 & 370 & 260 & 355 & 305 & 270 & 335 \\ \mathbf{2 0 1 5} & 175 & 235 & 365 & 245 & 330 & 250 & 255 & 300 \\ \mathbf{2 0 1 6} & 170 & 220 & 345 & 240 & 320 & 225 & 240 & 290 \\ \mathbf{2 0 1 7} & 155 & 205 & 305 & 230 & 290 & 200 & 225 & 265 \\ \mathbf{2 0 1 8} & 150 & 200 & 290 & 220 & 280 & 190 & 215 & 260 \\ \mathbf{2 0 1 9} & 145 & 185 & 280 & 215 & 285 & 175 & 205 & 250 \\ \mathbf{2 0 2 0} & 140 & 195 & 290 & 230 & 280 & 185 & 220 & 265\end{array}$

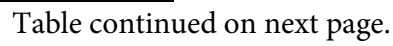


Appendix Table 7. Historical Average Cash Rental Rates of Nebraska Farmland for Different Types of Land by Agricultural Statistics District, 1981-2020 (continued)

\begin{tabular}{|c|c|c|c|c|c|c|c|c|}
\hline \multirow{2}{*}{$\begin{array}{c}\text { Type of } \\
\text { Land and } \\
\text { Year }\end{array}$} & \multicolumn{8}{|c|}{ Agricultural Statistics District } \\
\cline { 2 - 8 } & Northwest & North & Northeast & Central & East & Southwest & South & Southeast \\
\hline
\end{tabular}

Dryland Alfalfa

\begin{tabular}{|c|c|c|c|c|c|c|c|c|}
\hline 1981 & b & $\mathrm{b}$ & 53 & 47 & 56 & 31 & 45 & 45 \\
\hline 1982 & b & $\mathrm{b}$ & 57 & 47 & 64 & 31 & 43 & 47 \\
\hline 1983 & b & $\mathrm{b}$ & 56 & 43 & 64 & 32 & 43 & 50 \\
\hline 1984 & b & $\mathrm{b}$ & 50 & 46 & 63 & 36 & 44 & 45 \\
\hline 1985 & b & $\mathrm{b}$ & 50 & 44 & 59 & 28 & 42 & 40 \\
\hline 1986 & b & b & 47 & 32 & 52 & 25 & 44 & 40 \\
\hline 1987 & b & $\mathrm{b}$ & 41 & 32 & 53 & b & 41 & 37 \\
\hline 1988 & b & $\mathrm{b}$ & 52 & 36 & 58 & b & 42 & 39 \\
\hline 1989 & b & $\mathrm{b}$ & 59 & 41 & 64 & b & 56 & 48 \\
\hline 1990 & b & $\mathrm{b}$ & 62 & 49 & 67 & 30 & b & 48 \\
\hline 1991 & b & 38 & 62 & 57 & 71 & 28 & b & 49 \\
\hline 1992 & b & 36 & 56 & 46 & 58 & b & 50 & 48 \\
\hline 1993 & b & 27 & 65 & 47 & 66 & 31 & 50 & 54 \\
\hline 1994 & b & $\mathrm{b}$ & 65 & 46 & 70 & 37 & 51 & 52 \\
\hline 1995 & b & $\mathrm{b}$ & 68 & 50 & 73 & b & 54 & 57 \\
\hline 1996 & b & $\mathrm{b}$ & 68 & 52 & 78 & b & 51 & 54 \\
\hline 1997 & b & $\mathrm{b}$ & 72 & 56 & 82 & b & 54 & 60 \\
\hline 1998 & b & $\mathrm{b}$ & 79 & 58 & 86 & b & 59 & 64 \\
\hline 1999 & b & $\mathrm{b}$ & 80 & 54 & 82 & b & b & 64 \\
\hline 2000 & b & $\mathrm{b}$ & 80 & 56 & 82 & b & b & $\mathrm{b}$ \\
\hline 2001 & b & $\mathrm{b}$ & 79 & 53 & 79 & b & b & b \\
\hline 2002 & b & $\mathrm{b}$ & 86 & 55 & 82 & b & 56 & b \\
\hline 2003 & b & $\mathrm{b}$ & 84 & 62 & 77 & b & 53 & 68 \\
\hline 2004 & b & $\mathrm{b}$ & 92 & 63 & 85 & b & 53 & 74 \\
\hline 2005 & b & $\mathrm{b}$ & 90 & 59 & 82 & b & 58 & b \\
\hline 2006 & b & b & 89 & 54 & 87 & b & 59 & 80 \\
\hline 2007 & b & $\mathrm{b}$ & 105 & 63 & 96 & b & b & b \\
\hline 2008 & b & $\mathrm{b}$ & 126 & 73 & 120 & b & b & b \\
\hline 2009 & b & $\mathrm{b}$ & 121 & 68 & 120 & b & b & b \\
\hline
\end{tabular}

Table continued on next page. 
Appendix Table 7. Historical Average Cash Rental Rates of Nebraska Farmland for Different Types of Land by Agricultural Statistics District, 1981-2020 (continued)

\begin{tabular}{|c|c|c|c|c|c|c|c|c|}
\hline \multirow{2}{*}{$\begin{array}{c}\text { Type of } \\
\text { Land and } \\
\text { Year }\end{array}$} & \multicolumn{6}{|c|}{ Agricultural Statistics District } \\
\cline { 2 - 8 } & Northwest & North & Northeast & Central & East & Southwest & South & Southeast \\
\hline
\end{tabular}

Dryland Alfalfa

$\begin{array}{lrrrrrrrr}\mathbf{2 0 1 0} & \text { b } & \text { b } & 124 & 71 & 118 & \text { b } & \text { b } & \text { b } \\ \mathbf{2 0 1 1} & \text { b } & \text { b } & 152 & 81 & 140 & \text { b } & \text { b } & \text { b } \\ \mathbf{2 0 1 2} & \text { b } & \text { b } & 198 & 105 & 182 & \text { b } & \text { b } & \text { b } \\ \mathbf{2 0 1 3} & \text { b } & \text { b } & 235 & 122 & 200 & \text { b } & \text { b } & \text { b } \\ \mathbf{2 0 1 4} & 40 & 100 & 244 & 91 & 168 & 46 & 88 & 147 \\ \mathbf{2 0 1 5} & 30 & 75 & 220 & 85 & 165 & 35 & 80 & 140 \\ \mathbf{2 0 1 6} & 28 & 58 & 205 & 80 & 155 & 32 & 76 & 130 \\ \mathbf{2 0 1 7} & 26 & 47 & 190 & 75 & 160 & 30 & 71 & 120 \\ \mathbf{2 0 1 8} & 27 & 45 & 185 & 73 & 150 & 29 & 68 & 125 \\ \mathbf{2 0 1 9} & 24 & 44 & 180 & 71 & 155 & 28 & 65 & 120 \\ \mathbf{2 0 2 0} & 23 & 46 & 185 & 73 & 160 & 26 & 67 & 125\end{array}$

Table continued on next page. 
Appendix Table 7. Historical Average Cash Rental Rates of Nebraska Farmland for Different Types of Land by Agricultural Statistics District, 1981-2020 (continued)

\begin{tabular}{|c|c|c|c|c|c|c|c|c|}
\hline $\begin{array}{c}\text { Type of } \\
\text { Land and } \\
\text { Year }\end{array}$ & \multicolumn{7}{|c|}{ Agricultural Statistics District } \\
\cline { 2 - 8 } & Northwest & North & Northeast & Central & East & Southwest & South & Southeast \\
\hline
\end{tabular}

Irrigated Alfalfa

\begin{tabular}{|c|c|c|c|c|c|c|c|c|}
\hline 1981 & $\mathrm{~b}$ & $\mathrm{~b}$ & 88 & 92 & 96 & b & 90 & b \\
\hline 1982 & $\mathrm{~b}$ & $\mathrm{~b}$ & 75 & 87 & 100 & 56 & 90 & b \\
\hline 1983 & $\mathrm{~b}$ & $\mathrm{~b}$ & 78 & 89 & 105 & 70 & 84 & b \\
\hline 1984 & $\mathrm{~b}$ & $\mathrm{~b}$ & 80 & 83 & 96 & 68 & 84 & b \\
\hline 1985 & $\mathrm{~b}$ & $\mathrm{~b}$ & 74 & 80 & 87 & $\mathrm{~b}$ & 69 & b \\
\hline 1986 & $\mathrm{~b}$ & $\mathrm{~b}$ & 68 & 58 & 69 & $\mathrm{~b}$ & 68 & b \\
\hline 1987 & $\mathrm{~b}$ & $\mathrm{~b}$ & 61 & 62 & 70 & $b$ & 68 & b \\
\hline 1988 & $\mathrm{~b}$ & $\mathrm{~b}$ & 72 & 66 & 78 & $\mathrm{~b}$ & 68 & b \\
\hline 1989 & $\mathrm{~b}$ & $\mathrm{~b}$ & 89 & 88 & 92 & b & 100 & b \\
\hline 1990 & b & $\mathrm{b}$ & 96 & 95 & 93 & 90 & 111 & b \\
\hline 1991 & $\mathrm{~b}$ & $\mathrm{~b}$ & 98 & 98 & 102 & 78 & 98 & b \\
\hline 1992 & $\mathrm{~b}$ & $\mathrm{~b}$ & 88 & 81 & 82 & $\mathrm{~b}$ & 94 & b \\
\hline 1993 & $\mathrm{~b}$ & $\mathrm{~b}$ & 96 & 96 & 92 & $b$ & 100 & b \\
\hline 1994 & $\mathrm{~b}$ & $\mathrm{~b}$ & 99 & 93 & 101 & $\mathrm{~b}$ & 95 & b \\
\hline 1995 & $\mathrm{~b}$ & $\mathrm{~b}$ & 99 & 102 & 101 & $b$ & 103 & b \\
\hline 1996 & $\mathrm{~b}$ & $\mathrm{~b}$ & 108 & 106 & 108 & $b$ & 109 & b \\
\hline 1997 & $\mathrm{~b}$ & $\mathrm{~b}$ & 113 & 106 & 119 & $\mathrm{~b}$ & b & b \\
\hline 1998 & $\mathrm{~b}$ & $\mathrm{~b}$ & 118 & 112 & 124 & $\mathrm{~b}$ & b & b \\
\hline 1999 & $\mathrm{~b}$ & $\mathrm{~b}$ & 112 & 108 & 115 & $\mathrm{~b}$ & b & b \\
\hline 2000 & $\mathrm{~b}$ & $\mathrm{~b}$ & 105 & 107 & 114 & $b$ & b & b \\
\hline 2001 & $\mathrm{~b}$ & $\mathrm{~b}$ & 118 & 107 & 118 & $\mathrm{~b}$ & b & b \\
\hline 2002 & $\mathrm{~b}$ & $\mathrm{~b}$ & 124 & 111 & 121 & $\mathrm{~b}$ & 116 & $\mathrm{~b}$ \\
\hline 2003 & $\mathrm{~b}$ & $\mathrm{~b}$ & 125 & 121 & 124 & $\mathrm{~b}$ & 117 & $\mathrm{~b}$ \\
\hline 2004 & $\mathrm{~b}$ & $\mathrm{~b}$ & 132 & 126 & 128 & $\mathrm{~b}$ & 123 & 126 \\
\hline 2005 & $\mathrm{~b}$ & $\mathrm{~b}$ & 130 & 121 & 119 & $\mathrm{~b}$ & 124 & b \\
\hline 2006 & $\mathrm{~b}$ & $\mathrm{~b}$ & 132 & 123 & 120 & b & 125 & b \\
\hline 2007 & $\mathrm{~b}$ & $\mathrm{~b}$ & b & 138 & 162 & b & b & b \\
\hline 2008 & $\mathrm{~b}$ & $\mathrm{~b}$ & 142 & 165 & 172 & b & b & b \\
\hline 2009 & $\mathrm{~b}$ & $\mathrm{~b}$ & 158 & 159 & 170 & b & b & b \\
\hline
\end{tabular}

Table continued on next page. 
Appendix Table 7. Historical Average Cash Rental Rates of Nebraska Farmland for Different Types of Land by Agricultural Statistics District, 1981-2020 ${ }^{a}$ (continued)

\begin{tabular}{|c|c|c|c|c|c|c|c|c|}
\hline \multirow{2}{*}{$\begin{array}{c}\text { Type of } \\
\text { Land and } \\
\text { Year }\end{array}$} & \multicolumn{7}{|c|}{ Agricultural Statistics District } \\
\cline { 2 - 8 } & Northwest & North & Northeast & Central & East & Southwest & South & Southeast \\
\hline
\end{tabular}

Irrigated Alfalfa

$\begin{array}{lrrrrrrrr}\mathbf{2 0 1 0} & \text { b } & \text { b } & \text { b } & 153 & \text { b } & \text { b } & \text { b } & \text { b } \\ \mathbf{2 0 1 1} & \text { b } & \text { b } & \text { b } & 172 & \text { b } & \text { b } & \text { b } & \text { b } \\ \mathbf{2 0 1 2} & \text { b } & \text { b } & \text { b } & 197 & 265 & \text { b } & \text { b } & \text { b } \\ \mathbf{2 0 1 3} & \text { b } & \text { b } & \text { b } & 254 & 293 & \text { b } & \text { b } & \text { b } \\ \mathbf{2 0 1 4} & 198 & 250 & 350 & 216 & 275 & 211 & 240 & 335 \\ \mathbf{2 0 1 5} & 150 & 165 & 290 & 175 & 265 & 175 & 235 & 295 \\ \mathbf{2 0 1 6} & 145 & 155 & 260 & 170 & 255 & 165 & 215 & 280 \\ \mathbf{2 0 1 7} & 120 & 150 & 250 & 165 & 245 & 140 & 215 & 260 \\ \mathbf{2 0 1 8} & 115 & 140 & 245 & 195 & 240 & 135 & 195 & 230 \\ \mathbf{2 0 1 9} & 110 & 130 & 240 & 190 & 250 & 130 & 180 & 225 \\ & & & & & & & & \end{array}$

Table continued on next page. 
Appendix Table 7. Historical Average Cash Rental Rates of Nebraska Farmland for Different Types of Land by Agricultural Statistics District, 1981-2020 (continued)

\begin{tabular}{|c|c|c|c|c|c|c|c|c|}
\hline $\begin{array}{c}\text { Type of } \\
\text { Land and } \\
\text { Year }\end{array}$ & \multicolumn{7}{|c|}{ Agricultural Statistics District } \\
\cline { 2 - 8 } & Northwest & North & Northeast & Central & East & Southwest & South & Southeast \\
\hline
\end{tabular}

Other Hayland

\begin{tabular}{|c|c|c|c|c|c|c|c|c|}
\hline 1981 & b & 21 & b & 37 & 39 & 34 & $\mathrm{~b}$ & 34 \\
\hline 1982 & b & 18 & b & 30 & $b$ & $\mathrm{~b}$ & $\mathrm{~b}$ & 34 \\
\hline 1983 & b & b & b & 41 & $b$ & $\mathrm{~b}$ & b & 31 \\
\hline 1984 & b & b & b & 32 & 44 & 29 & $\mathrm{~b}$ & 36 \\
\hline 1985 & b & b & b & 38 & 38 & $\mathrm{~b}$ & b & 28 \\
\hline 1986 & b & b & b & 26 & 29 & b & b & 26 \\
\hline 1987 & b & b & b & 28 & 32 & b & b & 24 \\
\hline 1988 & b & b & b & 26 & 31 & $\mathrm{~b}$ & $\mathrm{~b}$ & 31 \\
\hline 1989 & b & b & b & 30 & 44 & b & b & 34 \\
\hline 1990 & b & b & b & 39 & 44 & 34 & $\mathrm{~b}$ & 38 \\
\hline 1991 & b & 18 & 37 & 37 & 43 & 35 & b & 33 \\
\hline 1992 & b & 21 & 31 & 30 & 34 & $\mathrm{~b}$ & 27 & 30 \\
\hline 1993 & b & 22 & 38 & 34 & 38 & b & 35 & 29 \\
\hline 1994 & b & b & 38 & 37 & 39 & $\mathrm{~b}$ & 33 & 29 \\
\hline 1995 & b & b & 41 & 40 & 44 & b & 31 & 34 \\
\hline 1996 & b & b & 42 & 40 & 40 & b & 31 & 36 \\
\hline 1997 & b & b & 42 & 43 & 44 & b & 32 & 38 \\
\hline 1998 & b & b & 48 & 43 & 50 & b & 35 & 40 \\
\hline 1999 & b & b & 48 & 38 & 48 & b & b & b \\
\hline 2000 & b & b & 48 & 35 & 43 & b & $\mathrm{b}$ & b \\
\hline 2001 & b & b & 50 & 37 & 47 & b & b & b \\
\hline 2002 & b & b & 50 & 38 & 51 & b & 36 & b \\
\hline 2003 & b & b & 46 & 36 & 53 & b & 33 & b \\
\hline 2004 & b & b & b & 42 & 57 & $\mathrm{~b}$ & 36 & 42 \\
\hline 2005 & b & b & 52 & 42 & 56 & b & 36 & b \\
\hline 2006 & b & b & b & 39 & 55 & b & 39 & b \\
\hline 2007 & b & b & b & 51 & $\mathrm{~b}$ & b & b & b \\
\hline 2008 & $\mathrm{~b}$ & b & b & 59 & $\mathrm{~b}$ & b & b & b \\
\hline 2009 & 27 & 29 & 67 & 57 & 71 & b & b & b \\
\hline
\end{tabular}

Table continued on next page. 
Appendix Table 7. Historical Average Cash Rental Rates of Nebraska Farmland for Different Types of Land by Agricultural Statistics District, 1981-2020ª (continued)

\begin{tabular}{|c|c|c|c|c|c|c|c|c|}
\hline \multirow{2}{*}{$\begin{array}{c}\text { Type of } \\
\text { Land and } \\
\text { Year }\end{array}$} & \multicolumn{8}{|c|}{ Agricultural Statistics District } \\
\cline { 2 - 9 } & Northwest & North & Northeast & Central & East & Southwest & South & Southeast \\
\hline
\end{tabular}

\section{Other Hayland}

$\begin{array}{rrrrrrrrr}\mathbf{2 0 1 0} & 27 & 29 & 52 & 57 & 61 & \text { b } & \text { b } & \text { b } \\ \mathbf{2 0 1 1} & \text { b } & \text { b } & \text { b } & \text { b } & \text { b } & \text { b } & \text { b } & \text { b } \\ \mathbf{2 0 1 2} & \text { b } & \text { b } & \text { b } & \text { b } & \text { b } & \text { b } & \text { b } & \text { b } \\ \mathbf{2 0 1 3} & \text { b } & \text { b } & \text { b } & 92 & 75 & \text { b } & \text { b } & \text { b } \\ \mathbf{2 0 1 4} & 33 & 55 & 138 & 40 & 78 & 39 & 58 & 89 \\ \mathbf{2 0 1 5} & 30 & 55 & 105 & 65 & 95 & 45 & 55 & 65 \\ \mathbf{2 0 1 6} & 27 & 53 & 98 & 62 & 86 & 41 & 50 & 62 \\ \mathbf{2 0 1 7} & 25 & 48 & 95 & 55 & 83 & 42 & 45 & 59 \\ \mathbf{2 0 1 8} & 22 & 46 & 100 & 54 & 85 & 39 & 44 & 57 \\ \mathbf{2 0 1 9} & 21 & 45 & 98 & 55 & 82 & 37 & 43 & 60 \\ \mathbf{2 0 2 0} & 20 & 43 & 105 & 57 & 85 & 38 & 45 & 64\end{array}$

Table continued on next page. 
Appendix Table 7. Historical Average Cash Rental Rates of Nebraska Farmland for Different Types of Land by Agricultural Statistics District, 1981-2020 (continued)

\begin{tabular}{|c|c|c|c|c|c|c|c|c|}
\hline \multirow{2}{*}{$\begin{array}{c}\text { Type of } \\
\text { Land and } \\
\text { Year }\end{array}$} & \multicolumn{6}{|c|}{ Agricultural Statistics District } \\
\cline { 2 - 8 } & Northwest & North & Northeast & Central & East & Southwest & South & Southeast \\
\hline
\end{tabular}

Pastureland (Per Acre)

\begin{tabular}{|c|c|c|c|c|c|c|c|c|}
\hline 1981 & 6 & 8 & 33 & 16 & 28 & 10 & 14 & 26 \\
\hline 1982 & 5 & 9 & 31 & 15 & 22 & 9 & 16 & 24 \\
\hline 1983 & 6 & 9 & 26 & 16 & 21 & 9 & 14 & 24 \\
\hline 1984 & 6 & 8 & 25 & 16 & 23 & 9 & 16 & 23 \\
\hline 1985 & 5 & 6 & 20 & 13 & 23 & 7 & 14 & 20 \\
\hline 1986 & 5 & b & 16 & 10 & 22 & 6 & 10 & 16 \\
\hline 1987 & 4 & 4 & 18 & 10 & 20 & 5 & 11 & 15 \\
\hline 1988 & 4 & 5 & 20 & 12 & 21 & 6 & 12 & 18 \\
\hline 1989 & 5 & 7 & 23 & 15 & 23 & 7 & 15 & 19 \\
\hline 1990 & 5 & 9 & 25 & 17 & 25 & 9 & 15 & 20 \\
\hline 1991 & 6 & 10 & 26 & 20 & 27 & 10 & 17 & 22 \\
\hline 1992 & 7 & 12 & 25 & 18 & 25 & 12 & 18 & 21 \\
\hline 1993 & 6 & 10 & 24 & 21 & 27 & 10 & 19 & 21 \\
\hline 1994 & 9 & 11 & 30 & 21 & 28 & 11 & 20 & 23 \\
\hline 1995 & 7 & 11 & 31 & 21 & 27 & 12 & 19 & 24 \\
\hline 1996 & 7 & 11 & 30 & 20 & 28 & 12 & 19 & 24 \\
\hline 1997 & 8 & 12 & 30 & 21 & 29 & 12 & 20 & 25 \\
\hline 1998 & 8 & 12 & 31 & 22 & 30 & 12 & 21 & 25 \\
\hline 1999 & 7 & 12 & 31 & 21 & 29 & 11 & 20 & 23 \\
\hline 2000 & 7 & 13 & 32 & 22 & 29 & 11 & 20 & 21 \\
\hline 2001 & 7 & 12 & 32 & 23 & 30 & 11 & 20 & 22 \\
\hline 2002 & 8 & 13 & 33 & 24 & 32 & 12 & 21 & 25 \\
\hline 2003 & 7 & 11 & 33 & 23 & 28 & 11 & 22 & 24 \\
\hline 2004 & 8 & 13 & 36 & 24 & 32 & 13 & 22 & 27 \\
\hline 2005 & 8 & 13 & 37 & 25 & 32 & 12 & 23 & 27 \\
\hline 2006 & 9 & 14 & 36 & 26 & 33 & 13 & 22 & 29 \\
\hline 2007 & 9 & 15 & 38 & 26 & 36 & 12 & 21 & 30 \\
\hline 2008 & 10 & 16 & 39 & 30 & 36 & 13 & 27 & 35 \\
\hline 2009 & 11 & 16 & 39 & 28 & 36 & 13 & 30 & 34 \\
\hline
\end{tabular}

Table continued on next page. 
Appendix Table 7. Historical Average Cash Rental Rates of Nebraska Farmland for Different Types of Land by Agricultural Statistics District, 1981-2020 (continued)

\begin{tabular}{|c|c|c|c|c|c|c|c|c|}
\hline \multirow{2}{*}{$\begin{array}{c}\text { Type of } \\
\text { Land and } \\
\text { Year }\end{array}$} & \multicolumn{6}{|c|}{ Agricultural Statistics District } \\
\cline { 2 - 8 } & Northwest & North & Northeast & Central & East & Southwest & South & Southeast \\
\hline
\end{tabular}

Pastureland (Per Acre)

$\begin{array}{lllllllll}\mathbf{2 0 1 0} & 11 & 14 & 40 & 27 & 35 & 13 & 29 & 32 \\ \mathbf{2 0 1 1} & 11 & 14 & 47 & 30 & 37 & 14 & 32 & 34 \\ \mathbf{2 0 1 2} & 13 & 16 & 51 & 33 & 42 & 16 & 36 & 39 \\ \mathbf{2 0 1 3} & 13 & 16 & 53 & 35 & 49 & 17 & 37 & 42 \\ \mathbf{2 0 1 4} & 10 & 25 & 70 & 30 & 55 & 20 & 35 & 50 \\ \mathbf{2 0 1 5} & 14 & 30 & 90 & 40 & 65 & 25 & 40 & 55 \\ \mathbf{2 0 1 6} & 12 & 26 & 75 & 36 & 61 & 24 & 37 & 54 \\ \mathbf{2 0 1 7} & 11 & 25 & 62 & 34 & 53 & 22 & 35 & 49 \\ \mathbf{2 0 1 8} & 10 & 26 & 61 & 33 & 49 & 21 & 36 & 47 \\ \mathbf{2 0 1 9} & 11 & 24 & 59 & 31 & 47 & 19 & 34 & 46 \\ \mathbf{2 0 2 0} & 12 & 26 & 63 & 35 & 51 & 20 & 37 & 48\end{array}$

Table continued on next page. 
Appendix Table 7. Historical Average Cash Rental Rates of Nebraska Farmland for Different Types of Land by Agricultural Statistics District, 1981-2020 (continued)

\begin{tabular}{|c|c|c|c|c|c|c|c|c|}
\hline \multirow{2}{*}{$\begin{array}{c}\text { Type of } \\
\text { Land and } \\
\text { Year }\end{array}$} & \multicolumn{7}{|c|}{ Agricultural Statistics District } \\
\cline { 2 - 8 } & Northwest & North & Northeast & Central & East & Southwest & South & Southeast \\
\hline
\end{tabular}

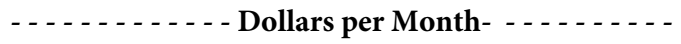

\section{Cow-Calf Pair (Per-Month)}

\begin{tabular}{|c|c|c|c|c|c|c|c|c|}
\hline 1981 & 13.00 & 13.30 & 12.85 & 15.80 & 12.65 & 14.40 & 13.75 & 12.90 \\
\hline 1982 & 13.00 & 12.50 & 15.25 & 15.95 & 13.85 & 16.00 & 15.00 & 14.95 \\
\hline 1983 & 13.40 & 16.60 & 16.50 & 16.65 & 14.50 & 15.45 & 15.21 & 15.81 \\
\hline 1984 & 13.20 & 15.90 & 15.30 & 16.55 & 14.10 & 15.25 & 14.75 & 15.60 \\
\hline 1985 & 12.20 & 12.70 & 12.90 & 13.00 & 12.80 & 13.60 & 12.80 & 13.60 \\
\hline 1986 & 10.70 & 10.50 & 11.00 & 10.60 & 10.10 & 10.40 & 10.70 & 11.30 \\
\hline 1987 & 9.55 & 10.35 & 10.10 & 10.55 & 10.20 & 10.25 & 10.50 & 10.50 \\
\hline 1988 & 9.50 & 11.00 & 10.90 & 11.30 & 13.00 & 12.70 & 12.65 & 13.50 \\
\hline 1989 & 11.35 & 14.50 & 14.00 & 14.50 & 13.25 & 12.80 & 14.20 & 13.70 \\
\hline 1990 & 12.90 & 16.75 & 15.55 & 17.80 & 15.70 & 17.40 & 15.00 & 15.35 \\
\hline 1991 & 14.85 & 20.00 & 18.00 & 20.30 & 19.50 & 18.25 & 17.50 & 18.00 \\
\hline 1992 & 14.60 & 21.00 & 18.80 & 19.95 & 17.40 & 17.65 & 19.00 & 18.00 \\
\hline 1993 & 16.40 & 21.30 & 18.50 & 22.35 & 19.85 & 20.75 & 20.40 & 19.85 \\
\hline 1994 & 17.20 & 23.25 & 19.70 & 23.00 & 21.55 & 23.00 & 23.00 & 21.60 \\
\hline 1995 & 16.75 & 23.40 & 19.90 & 23.00 & 20.50 & 22.30 & 22.20 & 20.30 \\
\hline 1996 & 16.40 & 23.00 & 18.35 & 21.80 & 21.00 & 20.35 & 21.15 & 20.05 \\
\hline 1997 & 17.00 & 23.50 & 20.50 & 22.25 & 22.30 & 21.20 & 21.20 & 20.75 \\
\hline 1998 & 18.10 & 23.70 & 21.00 & 23.40 & 23.60 & 23.40 & 22.20 & 21.70 \\
\hline 1999 & 16.70 & 23.00 & 21.60 & 23.25 & 21.90 & 23.25 & 22.00 & 20.40 \\
\hline 2000 & 18.25 & 23.15 & 23.80 & 23.80 & 22.50 & 24.50 & 22.00 & 21.35 \\
\hline 2001 & 19.65 & 25.10 & 23.40 & 24.45 & 24.00 & 25.00 & 22.20 & 22.75 \\
\hline 2002 & 20.35 & 26.35 & 23.80 & 25.10 & 24.30 & 25.00 & 23.30 & 24.40 \\
\hline 2003 & 19.15 & 26.15 & 25.10 & 24.90 & 24.45 & 24.60 & 23.00 & 23.15 \\
\hline 2004 & 21.00 & 27.65 & 26.80 & 26.35 & 26.00 & 26.25 & 24.00 & 25.15 \\
\hline 2005 & 23.15 & 28.30 & 28.10 & 28.55 & 27.90 & 26.70 & 24.60 & 25.15 \\
\hline 2006 & 23.00 & 29.40 & 29.70 & 28.70 & 28.00 & 26.70 & 26.00 & 25.80 \\
\hline 2007 & 25.00 & 29.55 & 29.15 & 27.75 & 26.00 & 25.70 & 25.00 & 25.15 \\
\hline 2008 & 26.25 & 33.65 & 31.90 & 33.10 & 31.60 & 31.40 & 27.75 & 29.85 \\
\hline 2009 & 26.90 & 33.60 & 33.00 & 33.35 & 30.70 & 30.50 & 30.00 & 29.50 \\
\hline
\end{tabular}

Table continued on next page. 
Appendix Table 7. Historical Average Cash Rental Rates of Nebraska Farmland for Different Types of Land by Agricultural Statistics District, 1981-2020 (continued)

\begin{tabular}{|c|c|c|c|c|c|c|c|c|}
\hline \multirow{2}{*}{$\begin{array}{c}\text { Type of } \\
\text { Land and } \\
\text { Year }\end{array}$} & \multicolumn{7}{|c|}{ Agricultural Statistics District } \\
\cline { 2 - 8 } & Northwest & North & Northeast & Central & East & Southwest & South & Southeast \\
\hline
\end{tabular}

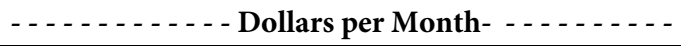

Cow-Calf Pair (Per-Month)

\begin{tabular}{|c|c|c|c|c|c|c|c|c|}
\hline 2010 & 26.40 & 33.00 & 33.60 & 32.90 & 31.25 & 29.50 & 28.50 & 30.80 \\
\hline 2011 & 28.00 & 34.00 & 35.70 & 33.30 & 35.80 & 33.85 & 32.00 & 32.90 \\
\hline 2012 & 30.80 & 38.60 & 40.00 & 38.10 & 38.35 & 37.00 & 38.30 & 38.20 \\
\hline 2013 & 30.50 & 39.00 & 42.35 & 40.75 & 41.30 & 39.20 & 39.00 & 39.40 \\
\hline 2014 & 32.30 & 48.55 & 55.00 & 59.95 & 49.00 & 45.45 & 32.10 & 43.00 \\
\hline 2015 & 39.40 & 65.55 & 62.05 & 67.10 & 64.55 & 60.70 & 57.50 & 58.90 \\
\hline 2016 & 36.15 & 63.80 & 59.70 & 58.10 & 56.40 & 57.20 & 49.10 & 52.00 \\
\hline 2017 & 35.05 & 61.05 & 53.20 & 53.30 & 51.10 & 51.65 & 47.30 & 48.50 \\
\hline 2018 & 35.65 & 58.95 & 52.55 & 52.30 & 48.25 & 49.50 & 46.45 & 47.05 \\
\hline 2019 & 36.15 & 57.50 & 54.90 & 50.70 & 49.15 & 46.35 & 44.10 & 45.15 \\
\hline 2020 & 37.90 & 61.45 & 57.80 & 54.70 & 51.35 & 49.90 & 47.10 & 50.45 \\
\hline
\end{tabular}

Source: a Panel members reported annual estimates of cash rental rates in the annual UNL Nebraska Farm Real Estate Market Surveys, 1981-2020.

${ }^{\mathrm{b}}$ Insufficient number of reports.

${ }^{c}$ A cow-calf pair is typically considered to be 1.25 to 1.30 animal units. However, this may vary depending on weight of cow and age of calf. 